\title{
Terrestrial Cosmogenic-Nuclide Dating of Alluvial Fans in Death Valley, California
}

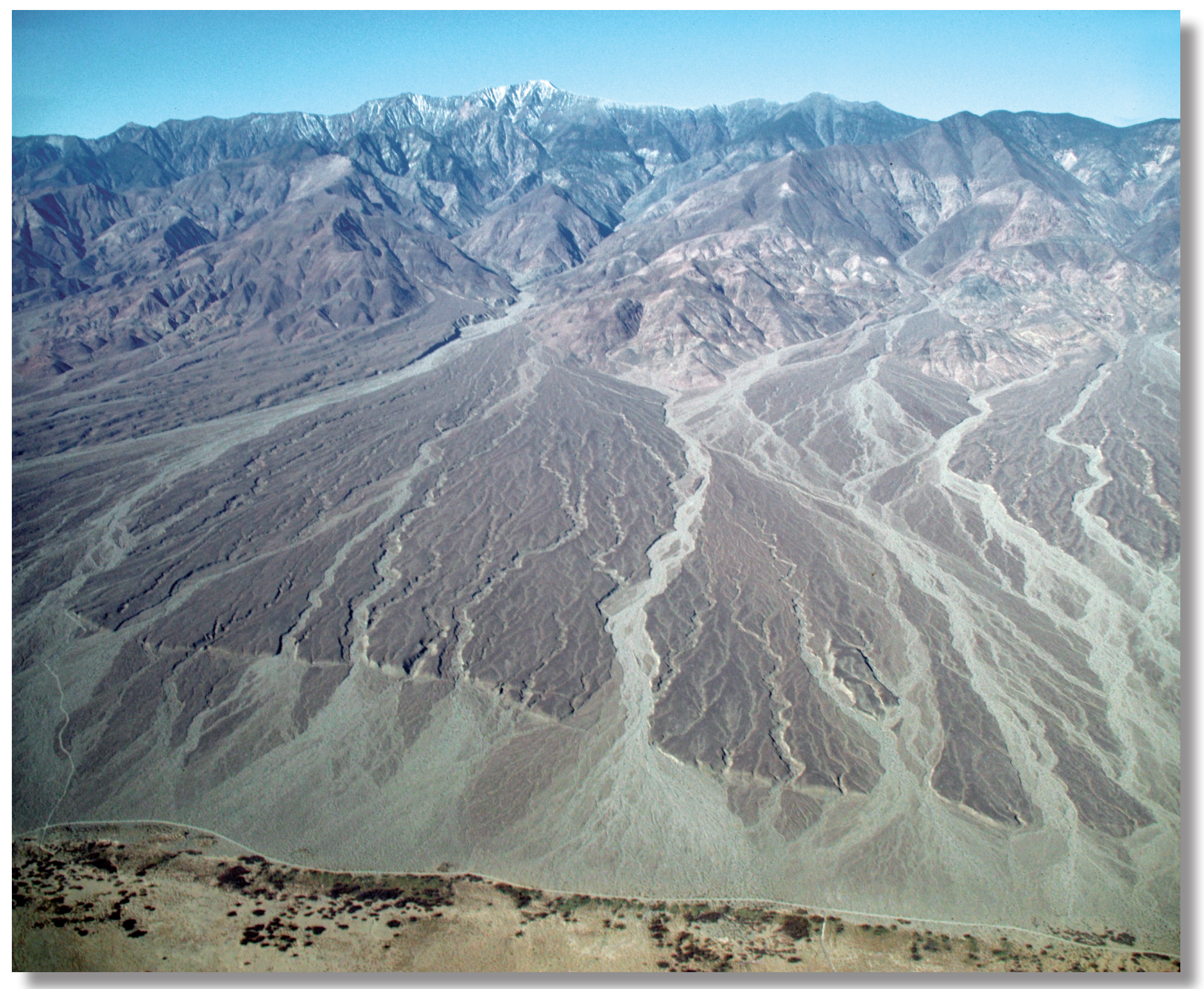

Professional Paper 1755 
Cover: Aerial photograph of the Hanaupah Canyon alluvial fan complex, view from the east. Courtesy of Marli Bryant Miller (2008). 


\section{Terrestrial Cosmogenic-Nuclide Dating of Alluvial Fans in Death Valley, California}

By Michael N. Machette, Janet L. Slate, and Fred M. Phillips

Professional Paper 1755 


\section{U.S. Department of the Interior DIRK KEMPTHORNE, Secretary}

\section{U.S. Geological Survey \\ Mark D. Myers, Director}

\section{U.S. Geological Survey, Reston, Virginia: 2008}

For product and ordering information:

World Wide Web: http://www.usgs.gov/pubprod

Telephone: 1-888-ASK-USGS

For more information on the USGS - the Federal source for science about the Earth, its natural and living resources, natural hazards, and the environment:

World Wide Web: http://www.usgs.gov

Telephone: 1-888-ASK-USGS

Any use of trade, product, or firm names is for descriptive purposes only and does not imply endorsement by the U.S. Government.

Although this report is in the public domain, permission must be secured from the individual copyright owners to reproduce any copyrighted materials contained within this report.

Suggested citation:

Machette, Michael N., Slate, Janet L., and Phillips, Fred M., 2008, Terrestrial Cosmogenic-Nuclide Dating of Alluvial Fans in Death Valley, California: U.S. Geological Survey Professional Paper 1755, 45 p. 


\section{Contents}

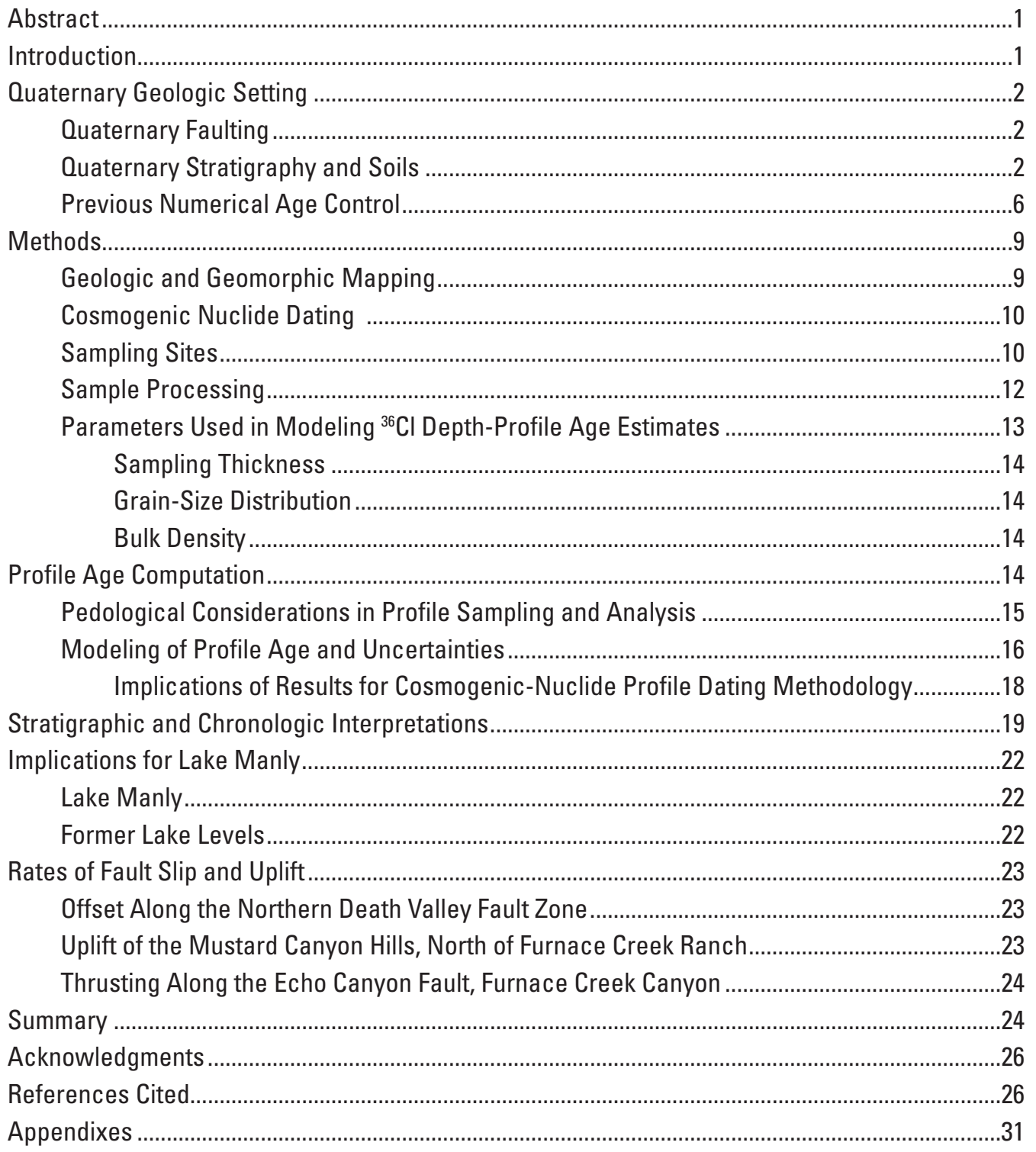




\section{Figures}

1. Computer-generated shaded relief map of the central part of Death Valley showing sampling areas and cultural and geographic features mentioned in the text.....

2. Satellite image of the central part of Death Valley showing alluvial fans and basin-floor playa 4

3. Oblique aerial photograph of the west-side alluvial fans from the base of the Panamint Range (300-360 meters above sea level) to the basin-floor salt pan (75 meters below sea level and lower).

4. Photograph of the lacustrine delta deposits preserved on north side of the Hanaupah Canyon fan complex.

5. Schematic diagram showing the temporal transition of geomorphic surfaces ...............8

6. Photograph of typical ${ }^{36} \mathrm{chlorine}$ depth-profile sampling site (S12) along the margin of an existing gravel road in Death Valley National Park

7. Photograph of relict, tafoni-weathered granitic boulder on distal Qai alluvial surface near sample site $\mathrm{S} 8$

8. Graph showing modeled ${ }^{36} \mathrm{Cl}$ accumulation with time and depth in the soil

9. Schematic diagrams showing (A) production of neutrons $(\mathrm{n})$ from cosmic ray protons $(p+)$ entering the Earth's atmosphere, and (B) production of ${ }^{36} \mathrm{Cl}$ in soil (or rock) materials due to spallation reactions on ${ }^{40} \mathrm{~K}$ and ${ }^{40} \mathrm{Ca}$ and low-energy neutron absorption by ${ }^{35} \mathrm{Cl}$

10. Diagram showing plot of sum-of-chi-squared $\left(\chi^{2}\right)$ values as a function of assumed erosion rate and age

11. Schematic diagram showing surficial geologic units encountered during ${ }^{36} \mathrm{Cl}$ depth-profile dating in Death Valley

12. Diagram showing plot of ${ }^{36} \mathrm{Cl}$ depth-profile ages for four surficial geologic units in Death Valley.

13. Eastward aerial view of the Mustard Canyon Hills, north of Furnace Creek....................24

14. Photograph showing the natural exposure of the Echo Canyon fault southwest-vergent thrusting of Qai alluvium over itself

\section{Tables}

1. Correlation of mapped surficial geologic units on Hanaupah fan, Death Valley, California .5

2. Suggested ages for mapped surficial deposits in Death Valley, California. .9

3. Summary of ${ }^{36} \mathrm{chlorine}$ sampling sites in Death Valley, California.

4. ${ }^{36} \mathrm{Cl}$ cosmogenic-nuclide age estimates for alluvial units, modern alluvium, and relict boulders in Death Valley National Park, California.

5. Suggested chronology for middle to late Quaternary surficial deposits in Death Valley based on new and published cosmogenic nuclide ages. 


\section{Appendix Tables}

A1. Locations of depth-profile sampling sites in Death Valley, California ..............................32

A2. Locations of sediment- and rock-sampling sites in Death Valley, California ...................33

A3. Sample information for ${ }^{36}$ chlorine depth-profile dating...................................................34

A4. Characteristics of Quaternary alluvial units, Death Valley, California................................37

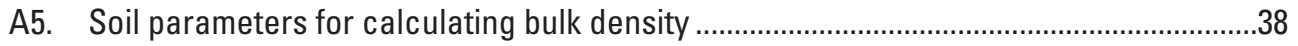

A6. Bulk-density calculations for depth-profile samples..........................................................40

A7. Slope aspect and orientation, elevation and orientation of the horizon for

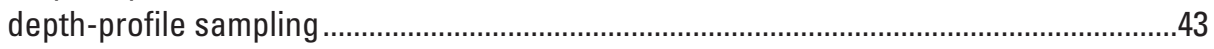

A8. Estimated surface erosion or aggradation rates for depth-profile sampling sites .........44

A9. (Excel spreadsheet: http://pubs.usgs.gov/pp/1755/downloads/TableA9_windows.xls) (PDF version: http://pubs.usgs.gov/pp/1755/downloads/TableA9_508.pdf)

Summary of terrestrial-cosmogenic nuclide depth-profile data for sampled Death Valley alluvial fans. 



\title{
Terrestrial Cosmogenic-Nuclide Dating of Alluvial Fans in Death Valley, California
}

\author{
By Michael N. Machette, Janet L. Slate, ${ }^{1}$ and Fred M. Phillips ${ }^{2}$
}

\section{Abstract}

We have used terrestrial cosmogenic nuclides (TCN) to establish the age of some of the most extensive Quaternary alluvial fans in Death Valley, California. These intermediateage alluvial fans are most extensive on the western side of the valley, where tectonic deformation is considerably less pronounced than on the eastern side of the valley. These fans are characterized by a relatively smooth, densely packed desert pavement formed by well-varnished (blackened) clasts. These surfaces have been mapped as the Q2 gravel by previous workers and as unit Qai (intermediate age) by us. However, the intermediate-age gravels probably contain multiple subunits, as evidenced by slight differences in morphologic expression, soil formation, and inset geomorphic relations. The TCN technique used herein sums the cosmogenic ${ }^{36} \mathrm{Cl}$ in approximately 2.5-meter-deep profiles through soil and host alluvium, thus avoiding some of the problems associated with the more typical surface-exposure dating of boulders or smaller clasts.

Our $\mathrm{TCN}{ }^{36} \mathrm{Cl}$ dating of 12 depth profiles indicates that these intermediate-age (Qai) alluvial fans range from about 100 to 40 kilo-annum (ka), with a mean age of about $70 \mathrm{ka}$. An alternative interpretation is that alluvial unit Qai was deposited in two discrete episodes from 90 to $80 \mathrm{ka}$ and from 60 to $50 \mathrm{ka}$, before and after MIS (marine oxygen-isotope stage) 4 (respectively). Without an intermediate-age unit, such as MIS 4 lake deposits, we can neither disprove nor prove that Qai was deposited in two discrete intervals or over a longer range of time. Thus, in Death Valley, alluvial unit Qai largely brackets MIS 4, which is not associated with a deep phase of Lake Manly. These Qai fans extend to elevations of about -46 meters (150 feet below sea level) and have not been transgressed by Lake Manly, suggesting that MIS 4 or MIS 2 lakes were rather shallow in Death Valley, perhaps because they lacked inflow from surface runoff of the Sierra Nevada drainages through Panamint Valley and over Wingate Wash.

A remnant of ancient lake shoreline deposits that once extended across the Hanaupah Canyon fan constrains the

${ }^{1}$ Earth Surface Processes Team, U.S. Geological Survey, P.O. Box 25046, MS 980, Denver, CO 80225, U.S.A.

${ }^{2}$ Department of Earth and Environmental Science, New Mexico Institute of Mining and Technology, Socorro, NM 87801, U.S.A. timing and extent of the last deep cycle of Pleistocene Lake Manly. The lacustrine delta complex yields a ${ }^{36} \mathrm{Cl}$ depth-profile date of $130 \mathrm{ka}$, which is consistent with deposition during a highstand of Lake Manly at the end of MIS 6. These deposits are presently at an altitude of about 30 meters above sea level (asl), which relates to a lake with a maximum depth of about 115 meters. Remnants of shoreline deposits at higher elevations on the southern margin of the Hanaupah Canyon fan complex are cut across older alluvium (unit Qao) and may be related to an MIS 6 highstand of at least 67 meters asl or, more likely, an older (MIS 8 or earlier) highstand that is poorly preserved and still undated in the valley.

As part of our work on the west-side fans, we also dated an older phase of alluvial-fan deposits from the Trail Canyon fan complex, which is north of Hanaupah Canyon. $\mathrm{A}{ }^{36} \mathrm{Cl}$ depth-profile age of $170 \mathrm{ka}$ suggests alluvial deposition of unit Qaio (older phase of Qao) took place prior to the MIS 6 highstand of Lake Manly.

Knowing the absolute ages (or range in ages) of the intermediate-age (Qai) surfaces in Death Valley allows us to estimate the following rates of geologic processes: (1) a lateral slip rate of 5 millimeters per year for the northern Death Valley fault zone; (2) uplift of 50 meters in roughly the past 80,000 years for parts of the Mustard Canyon hills in eastcentral Death Valley; and (3) an estimated 10-40 m of dip-slip thrust movement on the Echo Canyon fault in Furnace Creek Canyon.

\section{Introduction}

The alluvial fans of Death Valley National Park are some of the most spectacular landscape features in the Southwestern United States. The widespread alluvial fans are a keystone of the Quaternary stratigraphy of the park and arid regions of North America (for example, Hunt and Mabey, 1966; Denny, 1965). In this context, the Death Valley alluvial fan chronology could be a proxy for regional paleoclimate if these deposits are tied to climatically driven alluvial-fan deposition and pluvial lake highstands during the Quaternary (Bull, 1991). Death Valley alluvial-fan deposits also are a key to understanding the Quaternary faulting of this classic pull-apart basin. However, the scarcity of datable carbonaceous $\left({ }^{14} \mathrm{C}\right)$ and 
luminescence (OSL) materials in these deposits, the severe climatic conditions of Death Valley, and the wilderness status of much of the park's wilderness have made determining absolute age of the Death Valley alluvial fans difficult.

Advances in terrestrial cosmogenic-nuclide (TCN) dating, which relies on the in-situ accumulation of nuclides such as ${ }^{10} \mathrm{Be},{ }^{23} \mathrm{Al}$, or ${ }^{36} \mathrm{Cl}$ in rock, allows dating of alluvial-fan materials independent of the more traditional radiocarbon and luminescence methods (Gosse and Phillips, 2001), which are typically limited to the past $40 \mathrm{ka}$. In this study, we measured the total accumulation of ${ }^{36} \mathrm{Cl}$ in pebble-size gravel in 2.5-m-deep backhoe pits excavated into Death Valley alluvial fans along existing roads (an environmental requirement for the park) or subjacent natural exposures. The depth-profile technique used herein differs from surface-exposure dating of boulders (see also Nishiizumi and others, 1993). Surfaceexposure dating relies on dating of multiple boulders and determining the probable age from the mean of the determinations without direct measurement of any inherited component of age. However, for the depth-profile approach we measured ${ }^{36} \mathrm{Cl}$ concentrations from four or five positions in a 2- to 3-m-deep profile and modeled the inherited ${ }^{36} \mathrm{Cl}$ component in the alluvium. The resulting depth profiles of ${ }^{36} \mathrm{Cl}$ accumulation are similar to those of soil parameters, such as silt, clay, or carbonate content, in that the strongest concentrations of the nuclides are at the top and have exponentially declining concentration with depth.

Although Quaternary stratigraphic frameworks are built on geologic relations, age relations are typically based on geomorphic expression (relative dating) and limited application of radiocarbon or luminescence dating in desert environments. However, with the advent of terrestrial cosmogenic-nuclide dating, we can now add numerical age control to stratigraphic units and calculate rates of processes like tectonics, soil formation, and erosion. The time range for terrestrial cosmogenic-nuclide dating with ${ }^{36} \mathrm{Cl}$ is probably late and middle Pleistocene, which greatly exceeds the common bounds of radiocarbon dating $(0-40 \mathrm{ka})$ and luminescence dating (100 ka to perhaps $200 \mathrm{ka}$ ). More important, it requires no particular lithologies or materials other than abraded rock clasts (gravel) that are commonly present in the upper 2-3 $\mathrm{m}$ of Quaternary deposits.

\section{Quaternary Geologic Setting}

\section{Quaternary Faulting}

Death Valley is a right-lateral pull-apart basin whose modern floor lies 60-85 $\mathrm{m}$ below sea level (Burchfiel and Stewart, 1966; Hunt and Mabey, 1966). Our study has been restricted to the central part of the basin, where the stratigraphic and structural relations of the Quaternary deposits and fault are well displayed. In this area, Death Valley is bounded by the Panamint and Black Mountains (fig. 1), which have been uplifted and tilted to the southeast during relatively rapid, late Neogene, northwest-directed extension along range-front normal faults (see Machette, Klinger, Knott, and others, 2001). As a result of the combined right-lateral shear and extension, Death Valley is composed of a series of complex, elongate, northwest-southeast-oriented subbasins with half-graben geometries (Mann and others, 1983; Machette, Klinger, Knott, and others, 2001) (fig. 1) that extend through the length of the park. On a broader scale, Death Valley is one of several subparallel basins in the southwestern Basin and Range Province that release strain through oblique right-lateral faulting in this rapidly north-northwest-extending portion of southeastern California (see Frankel and others, 2007), which has been referred to as the Eastern California Shear Zone by Dokka and Travis (1990).

The Death Valley fault system is the dominant geologic structure of Death Valley (Machette, Klinger, Knott, and others, 2001). Composed of three main fault zones, from north to south they include the Northern Death Valley (NDVfz), the Black Mountains (BMfz), and the Southern Death Valley (SDVfz). The Fish Lake Valley fault zone (FLVfz) is a northern extension of the NDVfz, but it lies north of Death Valley and has an opposing sense of oblique-sinistral movement, being down to the east (nomenclature of Machette, Klinger, Knott, and others, 2001). Of main interest to this study is the central part of Death Valley, which includes the BMfz on the east side and distributed normal faults on the west side on alluvial fans, which flank the Panamint Mountains block.

In Death Valley, the east-side faults of the Black Mountains fault zone are extremely active in controlling basin subsidence, whereas the west-side faults are more passive and relatively discontinuous (that is, minor). The extreme differences in slip rate, total throw, and continuity of faulting on the opposing margins of the valley have led to a dichotomy in the form and age of the alluvial fans on opposing sides of the basin (fig. 2). This dichotomy has been noticed for nearly a century and is a direct response to active tectonism in Death Valley (see various papers in Machette, Johnson, and Slate, 2001).

\section{Quaternary Stratigraphy and Soils}

The alluvial fans on the west side of the valley, which emanate from the Panamint Range, are massive, coalesced alluvial fans cored by sedimentary wedges of early(?) Pleistocene to Holocene age, whereas the east-side fans, adjacent to the tectonically active Black Mountains fault zone (fig. 2), are of latest Pleistocene and Holocene age and are typically smaller and steeper (fig. 1). The alluvial fans are generally smaller and younger on the eastern side but are larger and older on the western side (fig. 2) of the valley (Whipple and Trayler, 1996). The intermediate-age fans are the focus of our study because they are older, more extensive, well preserved, and not as deformed as those on the eastern side. Equally important is the fact that they could be sampled in deep 


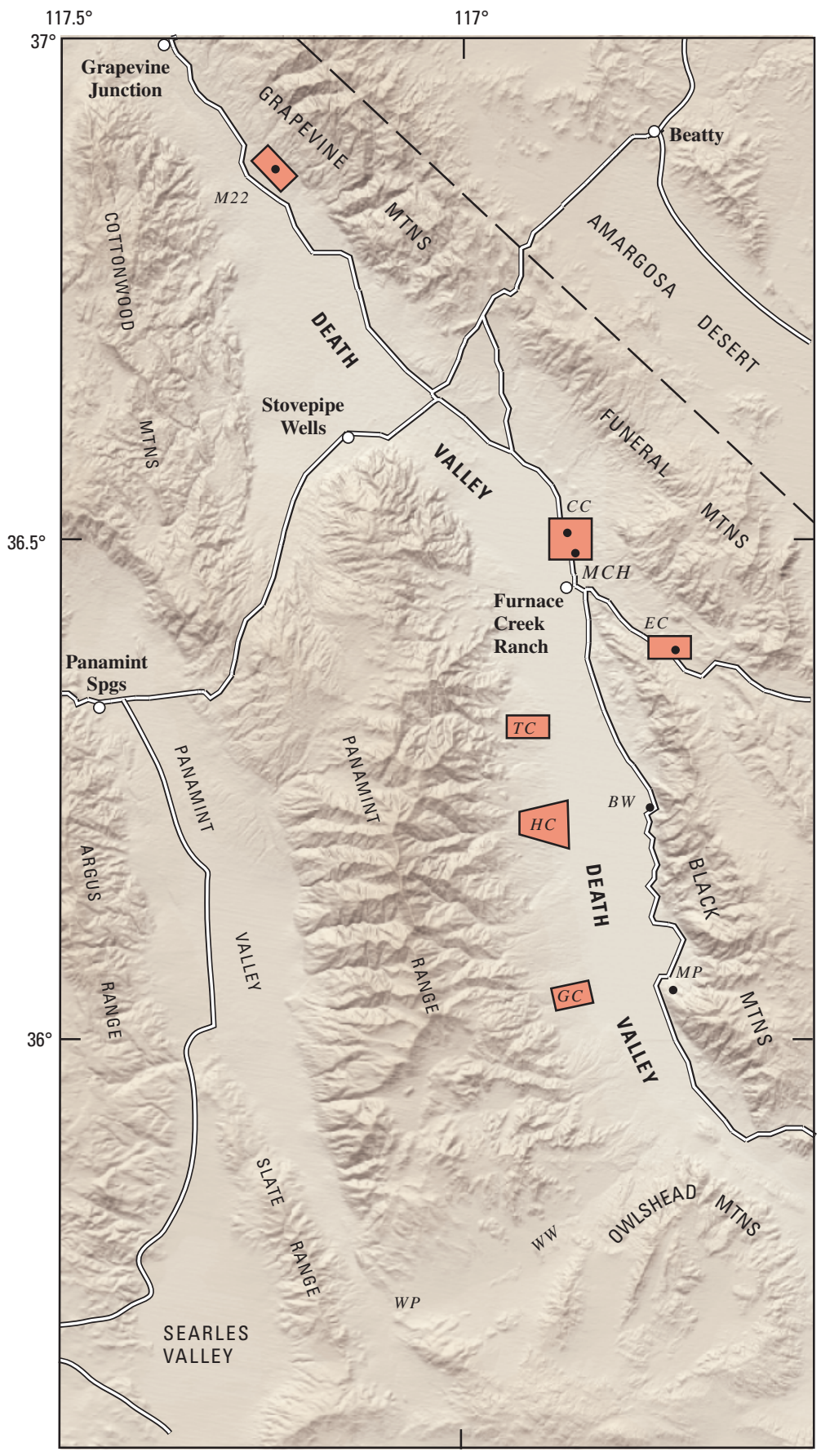

EXPLANATION

$\begin{array}{ll}B W-\text { Badwater } & M C H-\text { Mustard Canyon Hills } \\ C C-\text { Cow Creek } & M P-\text { Mormon Point } \\ E C-\text { Echo Canyon } & T C-\text { Trail Canyon } \\ G C-\text { Galena Canyon } & W P-\text { Wingate Pass } \\ H C-\text { Hanaupah Canyon } & W W-\text { Wingate Wash } \\ M 22-\text { Mile 22 } & \end{array}$

Figure 1. Computer-generated shaded relief map of the central part of Death Valley showing sampling areas and cultural and geographic features mentioned in the text. 


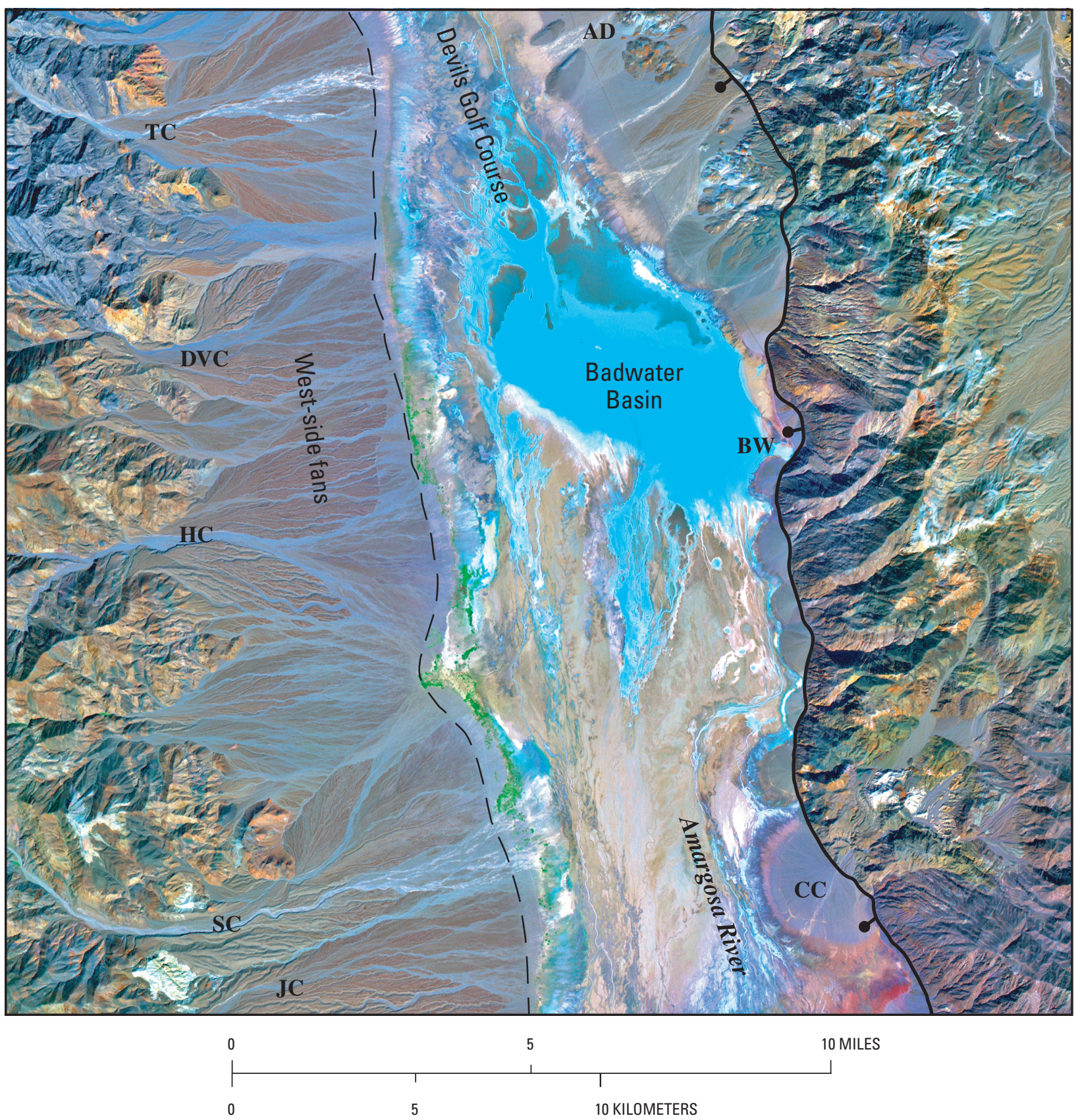

\section{EXPLANATION}

$\begin{array}{lll}\text { Lacustrine trim line } & \text { AD-Artists Drive } \\ \text { on fans } & \text { BW-Badwater } \\ & \text { Black Mountains } & \text { DVC-Copper Canyon } \\ \text { fault zone } & \text { HC-Hanaupah Canyon } \\ & \text { JC-Johnson Canyon } \\ & \text { SC-Starvation Canyon } \\ & \text { TC-Trail Canyon }\end{array}$

Figure 2. Satellite image of the central part of Death Valley showing alluvial fans and basin-floor playa. The west-side fans derived from the Panamint Mountains are very large, whereas the east-side fans are smaller owing to high rates of vertical movement and basin subsidence across the Black Mountains fault along the range front (shown as a heavy black line). Landsat 5 image from John Dohrenwend (2001, his fig. D-1) using bands 7, 4, and 2. 
backhoe pits along existing gravel roads, which was a primary requirement of our sampling permit.

C.B. Hunt established the first stratigraphic succession for the Quaternary deposits of Death Valley (table 1; Hunt and Mabey, 1966). His mapping units were fourfold: Qg4 (relatively young), Qg3, and Qg2 (relatively old). The fourth unit is the Pliocene-Pleistocene Funeral Formation as unit QTg1, although these deposits are uplifted, tilted and highly dissected, and lack the alluvial-fan morphology of the younger units ( $\mathrm{Qg} 2, \mathrm{Qg} 3$, and $\mathrm{Qg} 4)$. On the basis of tephrochronology, Knott and others (2000) have shown that the oldest alluvialfan deposits (Hunt's QTg1) along the base of the Panamint Range are late Pliocene in age. Denny (1965) published some of Hunt's mapping but used the same Quaternary stratigraphic subdivisions with different labels (table 1).

Building on this framework, Hooke (1972) delineated six discrete geomorphic units for the west-side fans. He made three subdivisions from the older gravel unit Qg2 previously mapped by Hunt and Mabey (1966) based on differences in color tone, dissection, and relief of the alluvial-fan surface.

Although most mappers have used a fourfold division, as introduced by Hunt and Mabey (1966), greater subdivision was needed for certain areas or applications (see Machette and others, 1999; Klinger and Sarna-Wojcicki, 2001; Klinger, 2003) especially where more refined age control is desired. Hooke and Dorn (1992) used accelerator-mass spectrometry (AMS) radiocarbon dates on rock varnish to establish the stratigraphic assemblage for the Hanaupah Canyon fan (table 1). However, rock varnish dating by radiocarbon methods is controversial (Gillespie, 1988; Beck and others, 1998; Watchman, 2000). The results from the Hooke and Dorn (1992) study have not been reproduced nor were the sampling parameters and site locations included in their published work; more important, their work has not been widely accepted by the scientific community. As a result, we simply present their stratigraphic subdivisions in table 1 for comparison with those of previous and more recent work. In Northern Death Valley, Klinger and Sarna-Wojcicki (2001) and Klinger (2003) subdivided the regional units based on surface morphology, soil characteristics, and geomorphic position (table A4) in order to better understand tectonic and stratigraphic relations. Menges and others (2001) and Workman and others (2002) have compiled the surficial geology of the Death Valley area and, although not as detailed as the mapping previously mentioned, they created a systematic map that incorporates and synthesizes mapping from the previous 50 years. This is the only published map that includes the entire north-to-south extent of Death Valley as well as areas to the east.

Stratigraphic relations between the alluvial fans and Lake Manly deposits, a pluvial lake that occupied the basin several times in the Quaternary (Hunt and Mabey, 1966; Machette, Klinger, Knott, and others, 2001), help constrain the age of the Q2 fans (correlated primarily with our unit Qai and Qao). Hunt and Mabey (1966) noted that the Q2 fans were inset below and are younger than Lake Manly deposits in all but three locations. Knott and others (2002) showed that deposits at Mormon Point with the morphology of Hunt's Q2 gravel are inset below 180-128-ka Lake Manly deposits that Ku and others (1998) dated by U-series on tufa perched on the Black Mountains above Badwater. These dates clearly show that the Q2 gravel is younger than the MIS 6 (marine oxygen-isotope stage) phase of Lake Manly. Q2 alluvial-fan deposits (our unit Qai) on the west side of the valley, which are the main dating target for this study, extend to elevations near $-46 \mathrm{~m}$ asl ( -150 $\mathrm{ft}$ asl) west of the West Side Road and show no evidence of having been transgressed by Lake Manly, which confirms Knott and others' (2002) conclusion. Thus, the depth of latest Pleistocene Lake Manly that postdates these fans must have

Table 1. Correlation of mapped surficial geologic units on Hanaupah fan, Death Valley, California.

\begin{tabular}{|c|c|c|c|c|c|}
\hline $\begin{array}{l}\text { Denny, } \\
1965\end{array}$ & $\begin{array}{c}\text { Hunt and Mabey, } \\
1966\end{array}$ & $\begin{array}{c}\text { 'Hooke, } \\
1972\end{array}$ & $\begin{array}{l}\text { Hooke and } \\
\text { Dorn, } 1992\end{array}$ & $\begin{array}{l}{ }^{2} \text { Nishiizumi and } \\
\text { others, } 1993\end{array}$ & $\begin{array}{l}{ }^{3} \text { This } \\
\text { report }\end{array}$ \\
\hline Qg & Qg4 & $\begin{array}{l}\text { Qa } \\
\text { Qai }\end{array}$ & Q4 & & Qay \\
\hline Qgv & Qg3 & Qat & & & Qayo \\
\hline \multirow{3}{*}{ Qgp } & \multirow{3}{*}{ Qg2 } & Qay & Q3 & $3 a$ & $\begin{array}{l}\text { Qai } \\
\text { Qaio }\end{array}$ \\
\hline & & Qai & Q2 & $2 a$ & Qao \\
\hline & & Qao & Q1 & $1 \mathrm{a}$ & QTa \\
\hline
\end{tabular}

${ }^{1}$ Hooke (1972, his fig. 4B) did not label his units, but patterned them according to facies and subdivided them (that is, active, inactive, trans., young, intermediate, and old). The map unit symbols shown above are based on his explanation for channel facies (Qc) deposits: a is active, $\mathrm{i}$ is inactive, and $\mathrm{t}$ is transitional to Lake Manly deposits. For surface facies (Qs) deposits: y is younger, $\mathrm{i}$ is intermediate, and o is older.

${ }^{2}$ Geologic map units based on Dorn (1988).

${ }^{3}$ Geologic map units based of Slate and others (in press). Qaio is an older part of unit Qai, not mapped by Slate and others (in press). 
been rather shallow, contrary to the popular concept of a deep MIS 2 Lake Manly proposed by Hooke (1972), Benson and others, 1990), and Anderson and Wells (2003).

The U-series chronology developed from tufas in shoreline deposits on the eastern side of Death Valley (Ku and others, 1998; Lowenstein and others, 1999), however, cannot readily be extended to the west-side alluvial fans owing to tectonism. On the north side of the Hanaupah Canyon fan complex, a remnant of a shoreline delta (unit Qlm) stands well above intermediate-age alluvial deposits (unit Qai) to the south (fig. 3). This delta was first recognized by Ibbeken and others (1998, p. 490) who noted that the surface pebbles are better sorted, rounded, and platy compared to alluvial-fan clasts. In a subsequent publication, Ibbeken and Warnke (2000) ascribed the clast sorting to lacustrine gravel of Lake Manly. Exposures on the northern flank of the delta show bottomset and foreset bedding (fig. 4) composed of open-work pebble to cobble gravel locally cemented by tufa. Our mapping shows that the upper part of the delta comprises a series of gently eastdipping planar surfaces (topset beds) and intervening slopes that probably are paleoshorelines of a once more extensive north-trending shoreline delta derived from streams emanating from Hanaupah Canyon. The uppermost (highest) surface of the delta is at $30 \mathrm{~m}$ asl (roughly equivalent to the $100-\mathrm{ft}$ topographic contour), well below the U-series dated MIS-6 shorelines that are uplifted east of the Black Mountains fault zone at Mormon Point (Knott and others, 2002) but well above the adjacent latest Pleistocene high shoreline mapped by Slate and others (in press).

In principle, the recognition of most Quaternary stratigraphic sequences has relied heavily on soil development as a relative indicator of the age of the underlying deposit (see Machette, 1985; Birkeland, 1999; and Birkeland and others, 1991, for examples). In general, soils only form on stable geomorphic surfaces; that is, those that become isolated from active stream erosion or deposition. In the arid geomorphic environment of the Death Valley, alluvial fans are typically formed at a fairly rapid rate by stream deposition or debris flows during flooding events (Bull, 1991). When deposition on the fan surface ceases, often as a result of stream downcutting or channel avulsion owing to tectonics or climate change, the surface becomes stabilized and pedogenic processes begin to operate (fig. 5A). As previously mentioned, in arid regions the early stages are dominated by atmospheric deposition of fine sediment and salts, with the result being formation of a fine-grained mantle (A horizon) and secondary accumulations of halite (near salty playas), gypsum, and calcium carbonate at increasing soil depths, respectively, depending on the aridity of the climate. In the Southwestern United States, the A horizons of arid soils commonly have weak accumulations of organic matter but strong accumulations of calcium carbonate-rich silt.

These A horizons develop vesicles in the silty matrix and thus are informally designated Av (vesicular) horizons (Birkeland, 1999). In the Death Valley area, a significant amount of eolian silt accumulates as a distinct layer on the surface of the parent material corresponding to the Av horizon (McFadden and others, 1998), but most of the calcium carbonate and some of the silt infiltrates into the profile and accumulates in the top 50-100 cm (Birkeland, 1999). Eventually, accumulation of these materials plugs the pore space in the substrate and runoff begins to increase, leading to enhanced erosion and stripping of the soil (Dohrenwend and others, 1986). This stripping is, of course, entirely derived from the top of the soil (fig. 5D).

\section{Previous Numerical Age Control}

Existing numerical age control for the Quaternary deposits of Death Valley is sparse and equivocal, at best. Radiocarbon dating helps control the uncommon deposits that contain charcoal that are less than $40 \mathrm{ka}$, whereas U-series dating of tufas in shoreline deposits and new cosmogenic dating of alluvial deposits is helping to build a chronology of surficial deposits. However, the best control to date comes from the basic law of superposition, which demonstrates that at Mormon Point, Q2 (Qai) morphology fans are younger than the 180-128-ka Lake Manly deposits (Ku and others, 1998; Knott and others, 2002).

On the west side, Nishiizumi and others (1993) used ${ }^{10} \mathrm{Be}-{ }^{26} \mathrm{Al}$ ratios to determine surface-exposure ages of boulders on the Hanaupah Canyon and Galena Canyon fans. They identified and sampled three alluvial surfaces on the upper part of the Hanaupah Canyon fan (table 2) and used the map units of Dorn (1988). Although their sampling sites are not well documented, comparison of aerial photography suggests that their youngest sampled surface (unit Q3a) is equivalent to our map unit Qai. They reported a minimum surface exposure age of 117 \pm 4 kyr (Nishiizumi and others, 1993, their table II). From the next higher and older surface (unit Q2a of Dorn, 1988; equivalent to our unit Qaoi), Nishiizumi and others (1993, their table II) reported an exposure age of $260 \pm 9 \mathrm{kyr}$ for a single boulder but considered it to be a minimum-age estimate owing to surface erosion. Finally, Niishizumi and others (1993) reported an exposure age of more than $314 \pm 22 \mathrm{kyr}$ for a boulder on the third and highest surface (unit Q1b of Dorn, 1988, equivalent to a young part of our unit QTa).

Although Nishiizumi and others (1993) suggested that the ballena landform of their Q1b deposits may be in erosional equilibrium, we believe that this relatively old ${ }^{10} \mathrm{Be}-{ }^{26} \mathrm{Al}$ exposure age is a minimum for the $\mathrm{Q} 1 \mathrm{~b}$ surface owing to surface erosion. In summary, although the ${ }^{10} \mathrm{Be}-{ }^{26} \mathrm{Al}$ exposure ages of Nishiizumi and others (1993) are in proper stratigraphic order (that is, higher surfaces are older), inherited components for the 117-kyr-dated sample (our unit Qai) were not considered, and the possibility of surface erosion of the sampled rocks makes the two older ages probable minimum estimates. For example, a boulder surface-erosion rate as low as $1 \mathrm{~mm} / \mathrm{kyr}$ over 200-400 kyr could markedly reduce their apparent ages.

In 2007, Miriam Dühnforth reported preliminary results of cosmogenic surface-exposure dating of alluvial-fan deposits in the Warm Springs fan complex, south of our study area in 


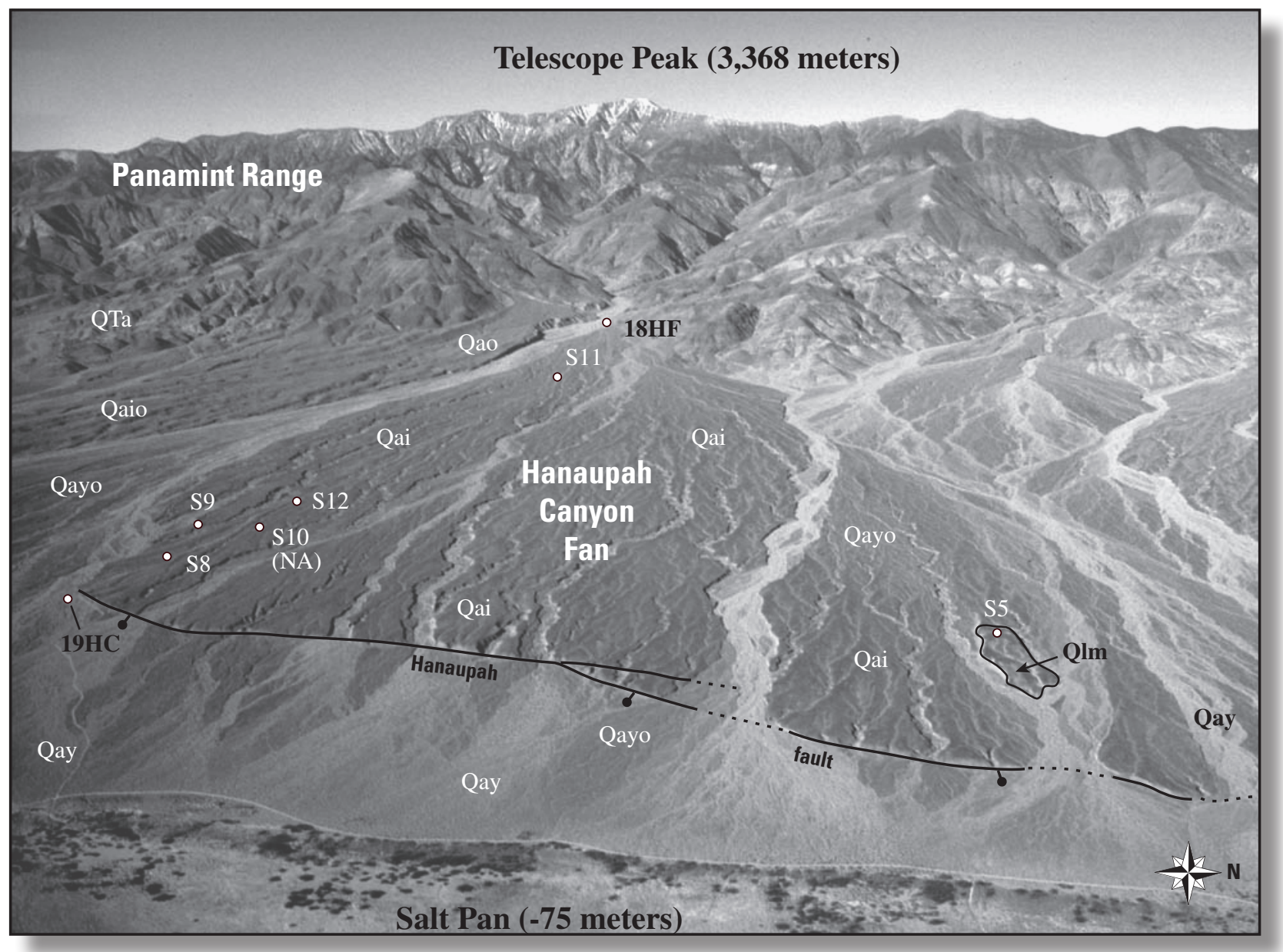

Figure 3. Oblique aerial photograph of the west-side alluvial fans from the base of the Panamint Range (300-360 meters above sea level) to the basin-floor salt pan (75 meters below sea level and lower). Note different tone and morphology of alluvial fan units. Terrestrial cosmogenic-nuclide sampling localities (for example, S5) are shown in white type; modern sediment samples (that is, 18HF) shown in black type. Bar and ball symbol marks the downthrown (eastern) side of the Hanaupah fault, which extends north-south across the toe of the Qai-age fan. A remnant of the lacustrine delta (S5, unit $0(\mathrm{~m})$ is preserved at the north end of the Hanaupah Canyon fan complex. 


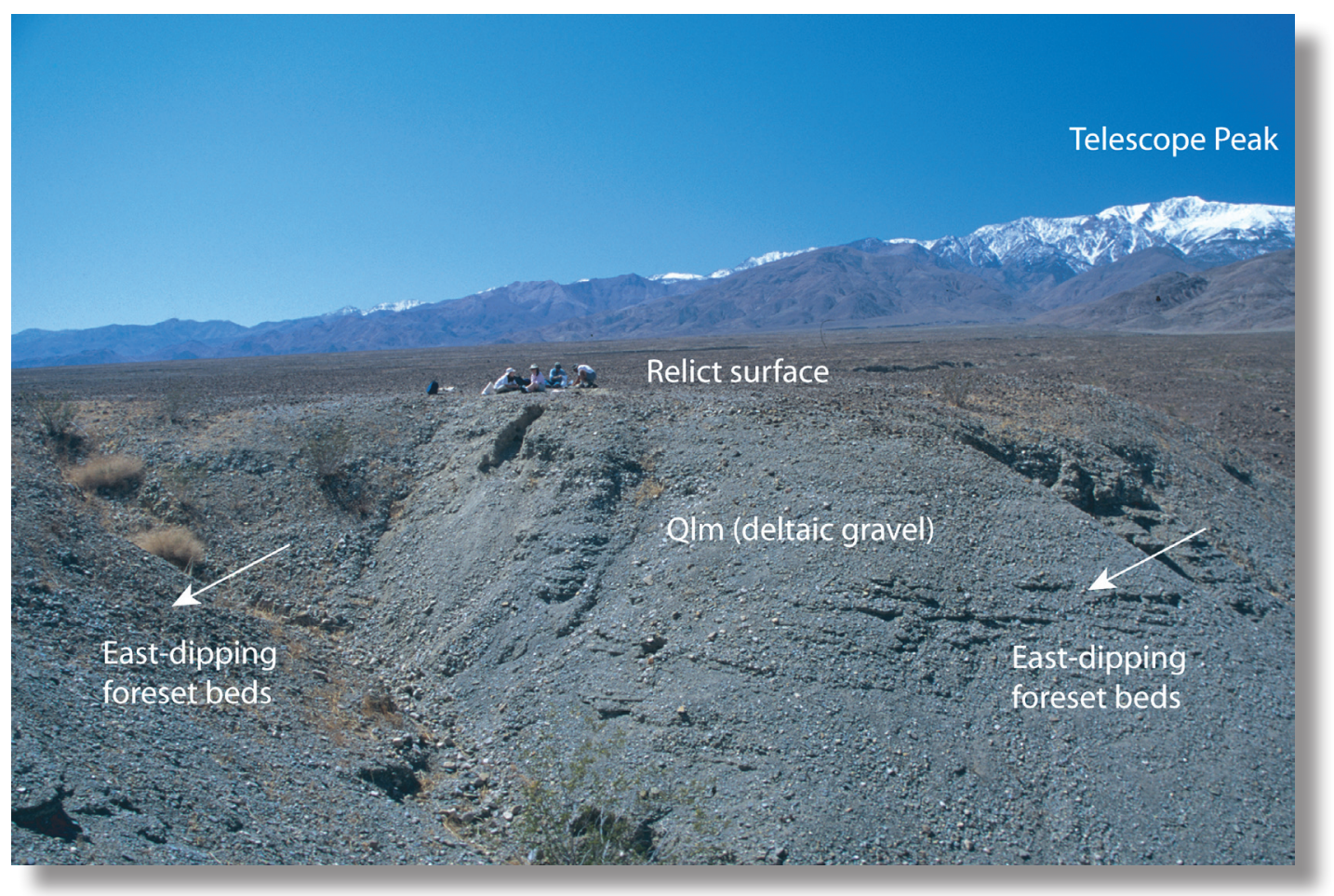

Figure 4. Lacustrine delta deposits preserved on north side of the Hanaupah Canyon fan complex. The open-framework pebble to small cobble gravel are moderately east-dipping foreset beds in the delta. Colleagues are separating samples on the relict surface of the delta, here at about 30 meters (100 feet) above sea level. View to south (valley floor is to left, east).

A. Late Holocene alluvium-Bar-and-swale morphology (10-50 centimeters of relief) and weak desert pavement
B. Latest Pleistocene (unit Qay)—Subdued bar-and-swale morphology (5-15 centimeters of relief) and moderate desert pavement
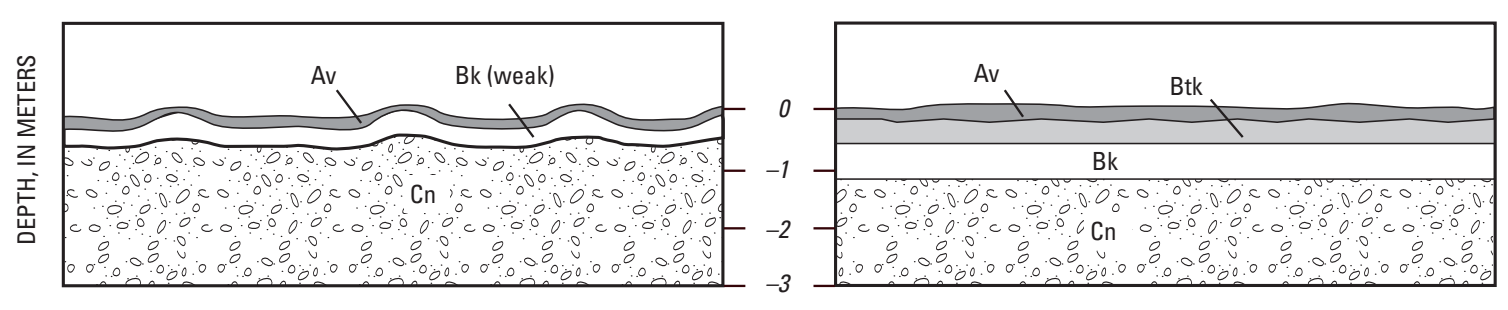

C. Late Pleistocene (unit Qai)—Flat, slightly dissected (1-2 meters), but strong desert pavement. Adjacent channels are $2-5$ meters deep

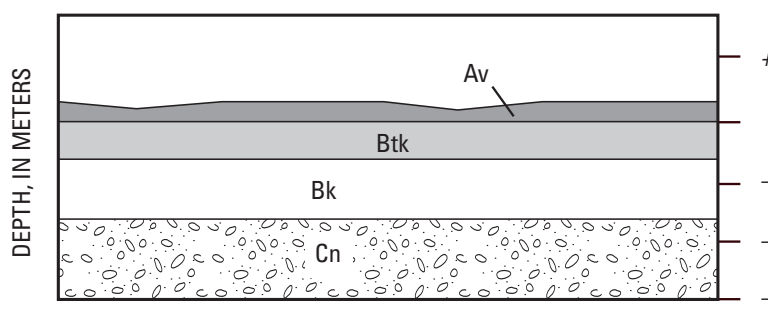

D. Middle Pleistocene (unit Qao) - Deeply dissected (2-5 meters), discontinuous pavement, thick accretionary $B$ horizons. Adjacent channels are 5-15 meters deep

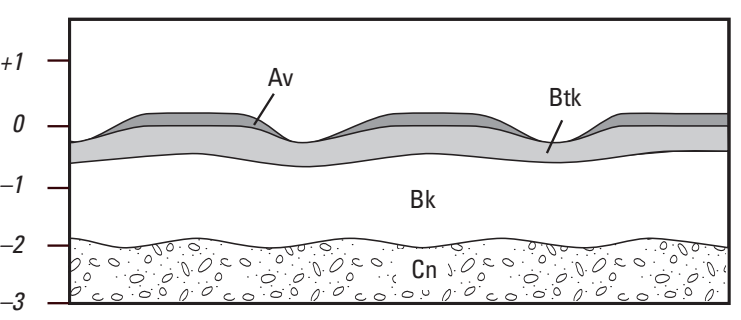

Figure 5. Schematic diagram showing the temporal transition of geomorphic surfaces. Transition is from recently deposited alluvial surfaces with bar and swale morphology $(A)$ to smooth surfaces $(B, C)$ and degraded surfaces (D) with attendant inflation of the soil owing to accumulation of silt and calcium carbonate in accretionary $B$ horizons. The micromorphology shown herein is for stable elements of larger geomorphic surfaces. 
Table 2. Suggested ages for mapped surficial deposits in Death Valley, California.

[Ma, mega-annum; ka, kilo-annum; <, less than; >, greater than; \pm plus or minus]

\begin{tabular}{|c|c|c|c|}
\hline $\begin{array}{c}\text { Geologic time } \\
\text { units }\end{array}$ & $\begin{array}{c}\text { 'Nishiizumi and } \\
\text { others, } 1993\end{array}$ & $\begin{array}{l}{ }^{2} \mathrm{~K} \text { linger, } \\
2003\end{array}$ & $\begin{array}{l}{ }^{3} \text { This } \\
\text { report }\end{array}$ \\
\hline Holocene $(<10 \mathrm{ka})$ & & $\begin{array}{c}\text { Q4b (historic) } \\
\text { Q4a (0.1-2 ka) } \\
\text { Q3c (2-4 ka) } \\
\text { Q3b (4-8 ka) } \\
\text { Q3a (8-12 ka) }\end{array}$ & $\begin{array}{l}\text { Qay } \\
(<12 \mathrm{ka})\end{array}$ \\
\hline $\begin{array}{l}\text { Late Pleistocene } \\
(10-130 \mathrm{ka})\end{array}$ & $\begin{array}{c}\text { Q3a } \\
(117 \pm 4 \mathrm{ka})\end{array}$ & $\begin{array}{l}\text { Q2c (12-70 ka) } \\
\text { Q2b (70-200 ka) }\end{array}$ & $\begin{array}{c}\text { Qayo } \\
(12-30 \mathrm{ka}) \\
\text { Qai } \\
(40-100 \mathrm{ka})\end{array}$ \\
\hline $\begin{array}{l}\text { Middle Pleistocene } \\
\quad(130-780 \mathrm{ka})\end{array}$ & $\begin{array}{c}\text { Q2a } \\
(>260 \pm 9 \mathrm{ka}) \\
\text { Q1b } \\
(>314 \pm 22 \mathrm{ka})\end{array}$ & Q2a (400-730 ka) & $\begin{array}{l}\text { Qlm }(130-180 \mathrm{ka}) \\
\text { Qaio }(150-220 \mathrm{ka}) \\
\text { Qao }(250-500 ? \mathrm{ka})\end{array}$ \\
\hline $\begin{array}{l}\text { Early Pleistocene to late(?) } \\
\text { Pliocene (>780 ka, <3 } \\
\text { Ma) }\end{array}$ & Q1 & $\mathrm{Q} 1(>1.2 \mathrm{Ma})$ & $\begin{array}{c}\text { QTa } \\
(760 \mathrm{ka} \text { to }<3 \mathrm{Ma})\end{array}$ \\
\hline
\end{tabular}

${ }^{1}$ Ages from surface-exposure dating of boulders (one per surface). The older dates are considered to be minimum ages owing to known amounts of surface erosion. Correlation of units based on mapping for this report.

${ }^{2}$ Ages estimated from soil development, geomorphology, and stratigraphic relations.

${ }^{3}$ General age designations estimated from soil development, geomorphology, and stratigraphic relations; independent of TCN results presented herein. Qaio is an older element of unit Qai; modified from Slate and others, in press.

Death Valley. This fan complex has both Pliocene and Pleistocene alluvial sediments, the older being associated with middle Pliocene volcanic ash beds (Knott and others, 2000). Dühnforth and others (2007) used cosmogenic ${ }^{10} \mathrm{Be}$ and ${ }^{26} \mathrm{Al}$ to date deposits equivalent to the Q2 and QTg1 gravels of Hunt (Hunt and Mabey, 1966), targeting quartzite pebbles. Dühnforth and others (2007) work, although preliminary, yielded surface-exposure dates that range widely (60-860 ka) and have a strong inherited component, commonly equivalent to 60-240 kyr as measured from modern alluvium. This area is strongly affected by faulting and has unrecognized subunits; many of the surfaces are deeply dissected and eroded, thus complicating the interpretation of their dating results. Nevertheless, the work of Dühnforth and others suggests that the alluvial fans of Death Valley have a history that includes most of Quaternary time.

To date, the most comprehensive mapping of alluvial fans has been that of Klinger (2003) who used soil development, geomorphic expression, and topographic position to map and correlate ages for alluvial fans in northern Death Valley. His stratigraphic units and age estimates are shown in table 2 as a framework for the surface exposure ages of Nishiizumi and others (1993) and Dühnforth and others (2007).

\section{Methods}

\section{Geologic and Geomorphic Mapping}

The stratigraphic framework for our dating studies are based on 1:24,000-scale mapping for the $30^{\prime} \times 60^{\prime}$ Death Valley Junction quadrangle $(1: 100,000$ scale, Slate and others, in press) with slight revisions and further subdivision of mapping units for the Hanaupah Canyon (fig. 3) and Devil's Speedway 7.5-minute quadrangles. Slate and others (in press) established a sixfold subdivision for the Quaternary and upper Pliocene alluvial deposits in Death Valley and the adjacent sedimentary basins (listed in table 1, note 3). Their reconnaissance mapping was principally based on aerial photograph interpretation using surface morphology, surface color tone, relative height above the active channel, and map pattern to differentiate among the alluvial units.

We used this mapping to identify potential excavation sites for the cosmogenic nuclide dating described herein. Our target sites were characterized by stable surfaces, intact soils, and minimal surface relief-all factors that would help ensure that the dates reflect time since deposition and thus the age of the underlying surficial deposits. 
From a geomorphic and stratigraphic viewpoint, we focused mainly on the darkly varnished, smooth Qai alluvial fans, which form a large part of the piedmont landscape of the valley. Older (pre-Qai) fans, which are more dissected and have strong carbonate accumulations at the surface, are not addressed herein, other than from a relative stratigraphic and chronologic sense. We found that younger (Qay) fans in this area are problematic for ${ }^{36} \mathrm{Cl}$ depth-profile dating owing to large inherited components of ${ }^{36} \mathrm{Cl}$ that commonly exceed the in-situ components. Along the eastern base of the Panamint Mountains, we sampled five depth profiles from Hanaupah Canyon (HC, fig. 1), one depth profile from Trail Canyon (TC, fig. 1) to the north, and two from Galena Canyon (GC, fig. 1) to the south. In addition, we sampled four profiles from faulted and folded Q2 fans on the eastern side of Death Valley in order to determine rates of deformation along the northern part of the Death Valley fault zone and associated structures (see also Frankel and others, 2007). Since this method is relatively new, we feel that it is important to include a large body of supporting spatial and laboratory data; conversely, in order to minimize the length of this report, all site location and sampling information is included in tables A1, A2, and A3 in the Appendixes.

\section{Cosmogenic Nuclide Dating}

Cosmogenic ${ }^{36} \mathrm{chlorine}\left({ }^{36} \mathrm{Cl}\right)$ is a stable isotope produced by the action of secondary cosmic-ray particles (principally neutrons) on potassium, calcium, and chlorine atoms in rocks within about $2 \mathrm{~m}$ of the Earth's surface (Phillips and others, 1986; Zreda and Phillips, 1994). Thus, if the production rate of ${ }^{36} \mathrm{Cl}$ is known, then earth materials can be dated by measuring the accumulation of ${ }^{36} \mathrm{Cl}$ or other cosmogenic nuclides in the rock at those depth intervals (Gosse and Phillips, 2001). Dating alluvial materials (pebbles in our case) can be difficult because the individual clasts may have an inherited component of cosmogenic nuclides at the time of deposition, which is then overprinted by an ever-growing in-situ component that accumulates following deposition and surface stabilization. The problem of nuclide inheritance has been addressed by "profile-dating," which allows the "inherited component" to be distinguished from the in-situ component (that accumulated after deposition) (Anderson and others, 1996). This distinction can be accomplished because the average inherited component should be relatively uniformly distributed through a depth profile in any single depositional unit, whereas the in-situ component should vary systematically with a characteristic quasi-exponential decrease of concentration with depth. This distinction in components is similar to that used to calculate the pedogenic accumulation of clay or calcium carbonate in soils (Machette, 1985; Birkeland, 1999). The depth-profile approach has been described in detail by Anderson and others (1996), Repka and others (1997), and Gosse and Phillips (2001) but had not been used in Death Valley owing to the requirement for 2- to 3-m-deep profiles and environmental/ sampling restrictions.

Numerous factors can affect the results of this type of ${ }^{36} \mathrm{Cl}$ depth-profile dating, including erosion, bioturbation, and sampling depositional units that originated from different source areas. Thus, we focused on relict geomorphic surfaces that showed the least obvious erosional, animal, or anthropogenic effects possible.

We collected profile samples, modern alluvium, and boulder-surface samples at sites along the west-side fans and at several localities associated with tectonic features on the eastern side of Death Valley (table 3). For the relict surfaces, we excavated backhoe pits to depths of 2.0-2.5 m or used fresh natural exposures (arroyo walls) to assure that the depositional materials were homogeneous. The sampled natural exposures had near-vertical faces that indicated recent (typically late Holocene) lateral incision and thus should have little or no postdissection exposure to cosmic rays; nevertheless, we dug back to expose fresh materials on these cut banks.

\section{Sampling Sites}

Our main target for ${ }^{36} \mathrm{Cl}$ depth-profile dating is the intermediate-age alluvium (unit Qai) from the west-side fans (fig. 1), although we sampled older alluvium (unit Qaoi) at one locality for comparison. A total of 10 backhoe pits (fig. 6) and 4 natural exposures were investigated, and 80 samples were obtained from these sites for depth-profile analysis; of these, 67 samples from 14 sites were analyzed for cosmogenic ${ }^{36} \mathrm{Cl}$ (table A3) and computing depth-profile ages. In addition, to directly compare the depth-profile ages with Nishiizumi and others' (1993) results, we sampled several large boulders for the more traditional surface-exposure dating approach.

The surficial layer (desert pavement and Av horizon) was not sampled for nuclide dating because it commonly is much younger than the underlying alluvium, so it was removed prior to excavation and set aside for environmental restoration. Bulk channel samples 10-15 cm thick were taken from both the soil pits and natural exposures, commonly at specific intervals distributed through the 2- to 2.5-m-depth profiles on the basis of abundant pebble-size clasts. We sieved these bulk samples to isolate the 0.5 - to 1.5 -cm-diameter clasts, which are best suited for the ${ }^{36} \mathrm{Cl}$ analysis as described herein. Finally, the soil profile was described for each site, and each horizon was sampled for characterization (texture, color, bulk density, selected chemistry, and so forth).

In addition to the strategy of deep sampling to assess the average inherited component in the profile, we sampled modern alluvial sediment from active streams that deposited the alluvial fans in the past (table A2 in the Appendixes) to evaluate the apparent age differences from an inherited component of cosmogenic ${ }^{36} \mathrm{Cl}$ as a result of transport distance. Four samples were evaluated: alluvium at the apices of the Trail and Hanaupah Canyon fans (proximal sediment) at the front of the Panamint Range and alluvium near the toes of 
Table 3. Summary of ${ }^{36} \mathrm{chlorine}$ sampling sites in Death Valley, California.

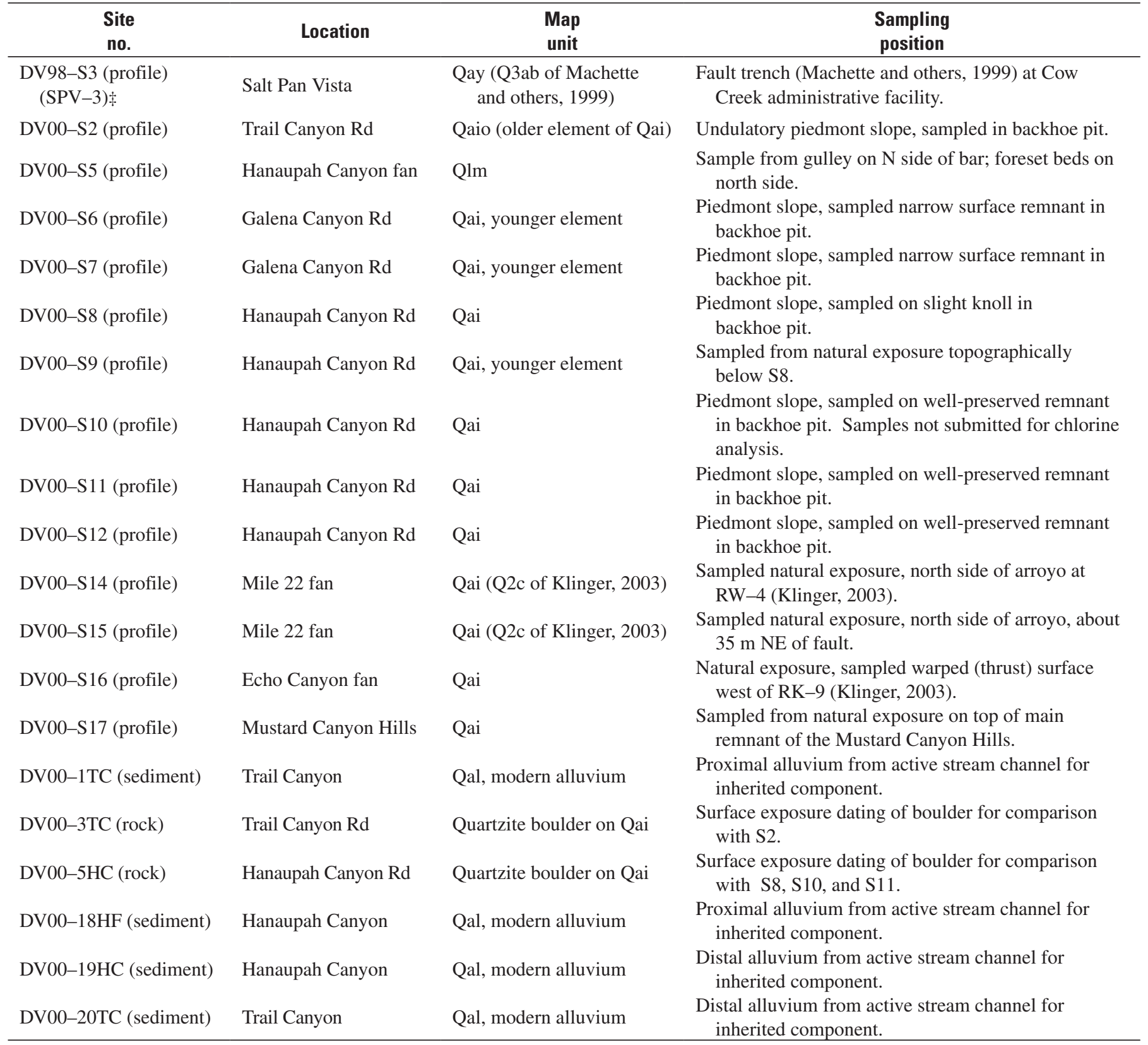

* This profile was dated by Machette and others (1999) as part of a seismic hazards study of the Cow Creek area. It is included in this table because it showed extremely large component of inherited chlorine. 


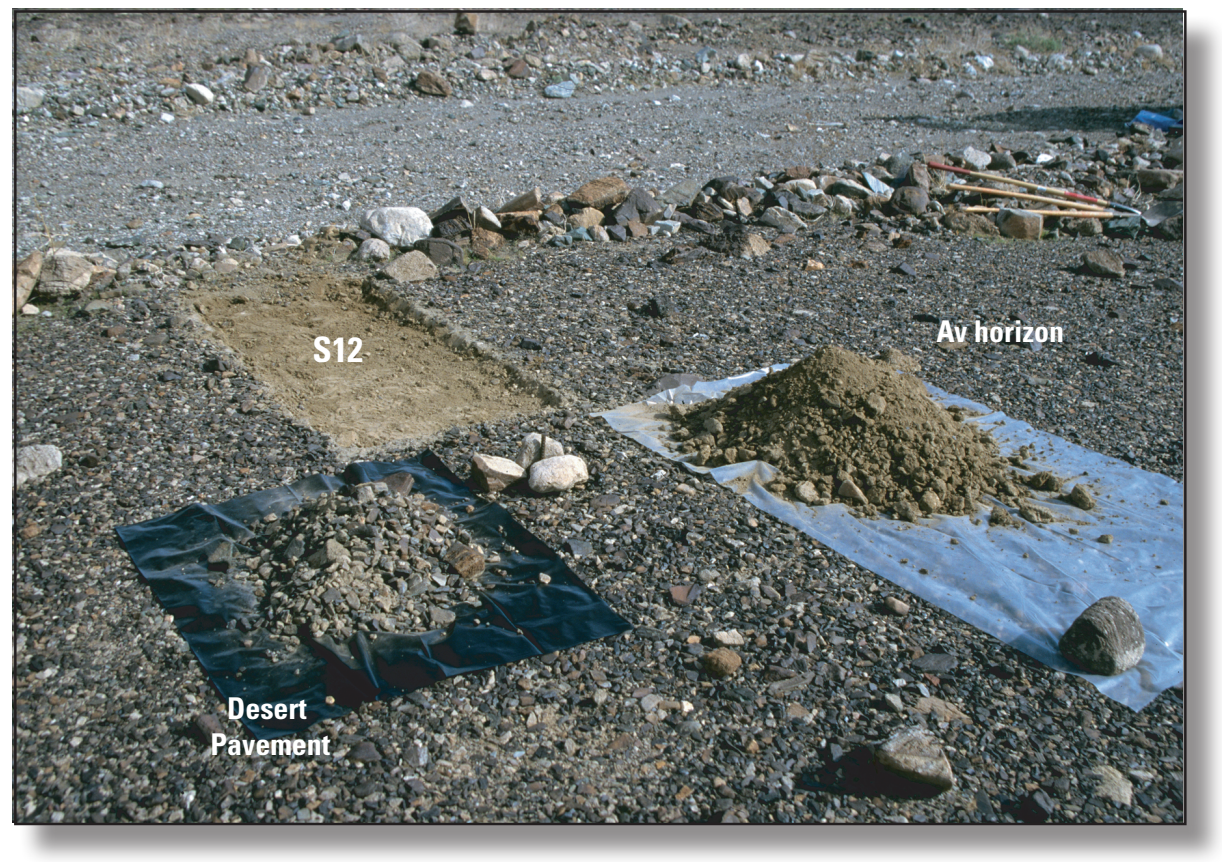

Figure 6. Photograph of typical ${ }^{36} \mathrm{chlorine}$ depth-profile sampling site (S12) along the margin of an existing gravel road in Death Valley National Park. Environmental concerns dictated that the varnished desert pavement and underlying $A$ horizon be removed prior to excavating backhoe pit, then restored after backfilling. Note that the desert pavement is relatively undisturbed beyond the road. Scraped area (roughly 1 meter by 2 meters) is where soil pit will be excavated.

the alluvial fans (distal sediment) close to the West Side Road (table 3).

We also sampled two large boulders (greater than 1 meter diameter) to compare results of the depth-profile dating to those of more conventional ${ }^{36} \mathrm{Cl}$ surface-exposure dating studies. Boulders are present on most of the alluvial surfaces of the west-side fans. However, the large size of the boulders (commonly 1-2 $\mathrm{m}$ in diameter) and the fact that they protrude well above the surfaces suggest that they may be of debrisflow origin and thus may not have been substantially eroded during transport. In addition, large boulders on the distal portion of the fans are commonly heavily weathered from alkali salts, which are ubiquitous in the nearby salt pans (fig. 3). For example, figure 7 shows a heavily weathered granitic boulder near sampling site S8 on the Hanaupah Canyon fan, about 3-4 km west of the Devils Golf Course (labeled Salt Pan in fig. 3). This boulder is completely eroded to the core. Using a rock chisel, we detached slabs ( $2-4 \mathrm{~cm}$ thick) from intact rock surfaces (fig. 7) on the top of each boulder and processed them for ${ }^{36} \mathrm{Cl}$, as described herein. Recognizing that each of the boulders has a unique but unknown depositional history, the few boulders we sampled can only compare in the most general way to more systematic profile dating of alluvium and to the previous surface-exposure dating of Nishiizumi and others (1993). For example, any of the boulders may have an inherited component of ${ }^{36} \mathrm{Cl}$, could have lost ${ }^{36} \mathrm{Cl}$ due to spalling or weathering, and (or) could have differential spatial concentrations of inherited ${ }^{36} \mathrm{Cl}$ related to their original orientation in the landscape. For example, some boulder tops may have been exposed to direct cosmic radiation in outcrop, or alternatively may have been covered, thus giving vastly different exposure histories. For surface-exposure dating, these problems are usually mitigated by sampling $6-10$ boulders and assuming that the mean age of the population approximates the time of emplacement (see Frankel and others, 2007, for a direct comparison of surface-exposure and depth-profile results). Conversely, for ${ }^{36} \mathrm{Cl}$ depth-profile dating we use a large collection of small pebbles, which were likely eroded during transport from upland positions.

\section{Sample Processing}

For each sampled interval, we sieved several kilograms of alluvium in the field and collected at least 150 clasts of 0.5 - to $1.5-\mathrm{cm}$ diameter to obtain an average exposure history for each sample and for the deposit as a whole. Averaging over a large number of clasts is necessary because each individual clast may have a different exposure history; our experience has indicated that using 150 clasts yields reproducible results for any given deposit (Phillips and others, 2003).

The pebbles were cleaned and ground to fine-sand size in a TEMA mill; then individually milled batches were carefully mixed to ensure a homogeneous sample. The pulverized 


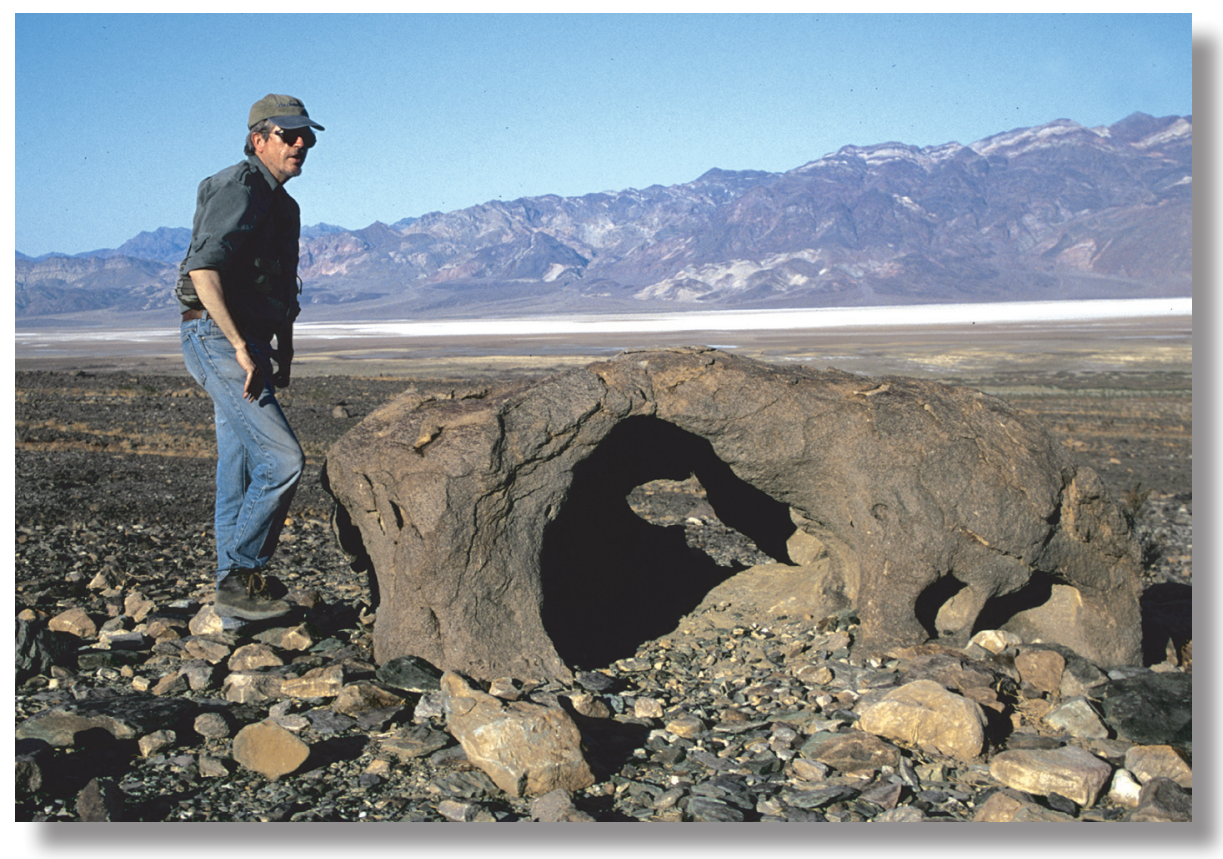

Figure 7. Photograph of relict, tafoni-weathered granitic boulder on distal Qai alluvial surface near sample siting S8. Salt weathering has completely removed the core of the boulder. Because of this weathering, we sampled boulders away from the salt pans that occupy the floor of Death Valley (fig. 3). View to the northeast; 6 -foot man for scale.

samples were leached in deionized water to remove ${ }^{36} \mathrm{Cl}$ derived from meteoric or atmospheric nuclear-weapons testing sources.

Aliquots of the sample were removed for elemental analysis. X-ray fluorescence analysis of major elements, as well as uranium (U) and thorium (Th), were performed at the New Mexico Bureau of Geology and Mineral Resources (NMBGMR), whereas gamma-emission spectrometry analysis of boron (B) and gadolinium (Gd) were performed by the XRAL Laboratory in Ontario, Canada.

In order to extract the chlorine component from the pulverized clasts, $80-125 \mathrm{~g}$ of rock powder was placed in 1-liter Teflon bottles with about $50 \mathrm{~g}$ of deionized water, about $50 \mathrm{~g}$ of nitric acid, about $250 \mathrm{~g}$ of hydrofluoric acid, and 1-3 mg of $\mathrm{Na}^{35} \mathrm{Cl}$. The latter chemical is an isotopically labeled carrier $\left({ }^{35} \mathrm{Cl} /{ }^{37} \mathrm{Cl}=99\right.$ percent $)$ that is needed to calibrate the chorine analyses. The rock powder samples were completely dissolved in 2 to 4 days' time, after which the supernatant was centrifuged and excess $\mathrm{AgNO}_{3}$ was added to precipitate both the natural chlorine and carrier chlorine.

The resulting silver chloride $(\mathrm{AgCl})$ precipitate was purified of sulfur (S), which interferes with the ${ }^{36} \mathrm{Cl}$ analysis, using standard procedures described in Zreda (1994). The purified and dried $\mathrm{AgCl}$ concentrate was sent to the PRIME Laboratory at Purdue University (Lafayette, Indiana) for accelerator-massspectrometry analyses of ${ }^{36} \mathrm{Cl} / \mathrm{Cl}$ (Elmore and others, 1979) and ${ }^{35} \mathrm{Cl} / \mathrm{Cl}$. The spreadsheet model "CHLOE" (Phillips and
Plummer, 1996) was used to calculate the ${ }^{36} \mathrm{Cl} / \mathrm{Cl}$ ratio and $\mathrm{Cl}$ concentration of the samples based on the ${ }^{36} \mathrm{Cl} / \mathrm{Cl}$ and ${ }^{35} \mathrm{Cl} / \mathrm{Cl}$ analyses, sample mass, and mass of added ${ }^{35} \mathrm{Cl}$ carrier.

\section{Parameters Used in Modeling ${ }^{36} \mathrm{CI}$ Depth-Profile Age Estimates}

The chlorine analyses, soil parameters, and sampling data were integrated to determine the amounts of chlorine isotopes in each sample and through the entire depth profile. These parameters include sampling thickness and depth, grain-size distribution, soil bulk density, clast density (for the gravel component), and an estimate of the amount of surface erosion (mass loss) or aggradation (mass gain) that has occurred since the sediment was deposited. Cosmic-ray flux decreases exponentially through the soil mass, so one must measure bulk density through the depth profile and the concentrations of potassium and calcium in the sampled material. In addition, other sampling-site data such as altitude of the site, location (latitude and longitude), slope aspect, and zenith orientation (position of the land/air horizon measured around the compass) are required to model cosmic-ray influx. The zenith orientation is used to compute cosmic-ray shielding by topographic barriers, such as local hills or distant mountain ranges. 


\section{Sampling Thickness}

Samples were taken from four or five nonuniform depths in each profile. Typically, the spacing between sample intervals was closest in the upper meter of the profile, where most of the in-situ cosmogenic chlorine resides, and increased with depth. This sampling approach better constrains that part of the profile where the greatest differences in ${ }^{36} \mathrm{Cl}$ content may be observed. For modeling, if a sample came from a depth interval (for example, 60-80 cm) (table A5, Column A), we used the average depth $(70 \mathrm{~cm})$ for that sample.

\section{Grain-Size Distribution}

In addition to the gravels that were collected for chlorine analysis, we collected bulk samples to determine the complete grain-size distribution of the alluvium (see columns B-D, table A5 in the Appendixes). The samples were sieved for greater than $2 \mathrm{~mm}$ and less than $2 \mathrm{~mm}$ contents; most of the alluvial deposits contained $65-80$ percent gravel, although silt infiltration in the upper meter of most profiles reduced the overall gravel component of some horizons to as little as $30-40$ percent. The uppermost layers of the soil consist of a stony desert pavement and a vesicular A horizon (Av) composed mostly of windblown and translocated silt and fine sand.

\section{Bulk Density}

Soil-ped (or clod) bulk density was measured using the paraffin-clod method (Singer and Janitzky, 1986). Direct measurement of bulk density was performed on those horizons with clods or peds that were coherent enough to be sampled and transported to the laboratory. The materials that we tested ranged from 1.22 to $1.7 \mathrm{~g} / \mathrm{cc}$ (see Column $\mathrm{F}$ of table $\mathrm{A} 5$ in the Appendixes), depending on the degree of compaction, clay content, and porosity. A standard bulk density of $2.65 \mathrm{~g} / \mathrm{cc}$ was assigned to all gravel clasts. The whole-soil bulk density for each sample is calculated from less than 2-mm and greater than 2-mm bulk densities and grain-size data (see Column H, table A5 in the Appendixes). For example, a sample containing 20 percent less than 2-mm fines (sand, silt and clay) having a bulk density of $1.5 \mathrm{~g} / \mathrm{cc}$ and 80 percent greater than 2-mm gravel having a density of $2.65 \mathrm{~g} / \mathrm{cc}$ yields a calculated whole-soil bulk density of $2.42 \mathrm{~g} / \mathrm{cc}$. The whole-soil bulk densities for each sampled interval are then incorporated in the depth profile, thereby giving downward-increasing cumulative soil mass per unit area. The cumulative masses per unit area are then used to calculate the shielding of a sample by overlying materials. These calculated data are listed in table A6 in the Appendixes.

In order to estimate cosmic-ray influx at each sampling site, we recorded altitude from topographic maps, latitude and longitude position by GPS, slope aspect using an Abney level, and horizon zenith orientation. For the zenith orientations, we measured the horizontal angle in degrees to the land/air interface using an Abney level at $30^{\circ}$ increments around the compass rose (that is, at azimuths of $0^{\circ}, 30^{\circ} \ldots 330^{\circ}$ ). All of the data that affect cosmic-ray influx are listed in table $\mathrm{A} 7 \mathrm{in}$ the Appendixes.

\section{Profile Age Computation}

As described above, the basic principle of cosmogenicnuclide dating is to use the observed systematic increase in cosmogenic nuclides with time to determine the length of time the deposit has been exposed to cosmic radiation (fig. 8). The variable history of the clasts that make up the alluvium complicates the premise of a systematic increase in cosmogenic nuclides. However, by collecting samples at multiple depths, the inherited component of the cosmogenic-nuclide inventory that is attributable to exposure before deposition can be separated from the in-situ cosmogenic component that is attributable to exposure after deposition (Anderson and others, 1996). In some cases, the shape of the cosmogenic-nuclide profile can also yield constraints on the rates of surface erosion or aggradation (Gosse and Phillips, 2001). Chlorine-36 depth profiles from stable surfaces typically exhibit a pronounced bulge due to upward diffusion of low-energy neutrons into the atmosphere and an exponential tail (fig. 8) owing to the progressive absorption of low-energy neutrons that are absorbed by ${ }^{35} \mathrm{Cl}$ to produce ${ }^{36} \mathrm{Cl}$. With increasing surface erosion, the magnitude of the bulge is diminished and the resulting truncated profile becomes more linear. If the profile is relatively regular and

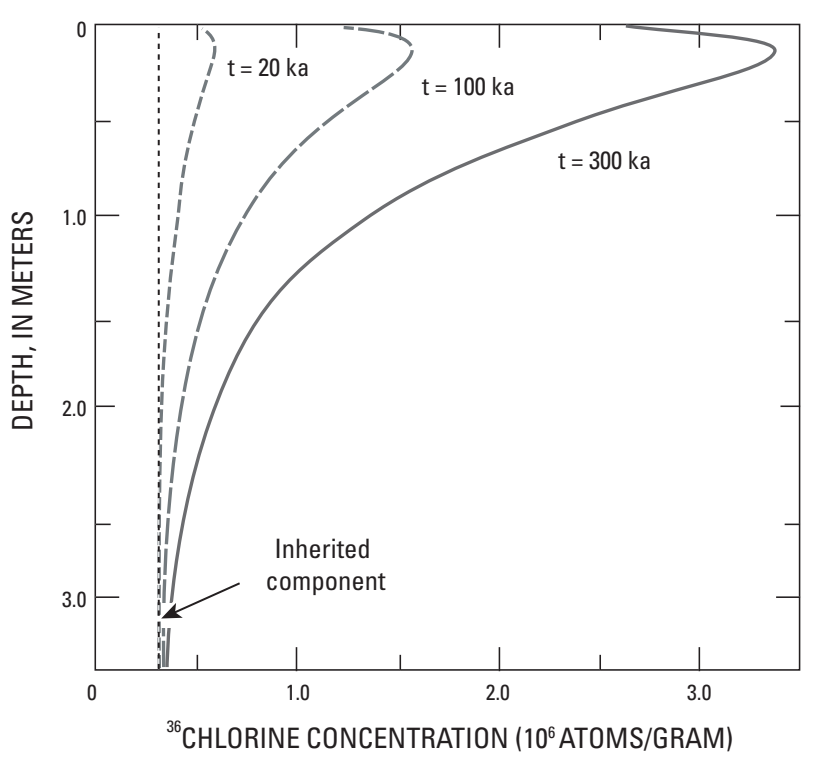

Figure 8. Modeled ${ }^{36} \mathrm{Cl}$ accumulation with time and depth in the soil. Note that the maximum concentration of ${ }^{36} \mathrm{C}$ remains in the upper 0.5 meter of the soil profile unless substantial erosion or burial has occurred. 
smooth, a theoretical curve can still be fitted to the data by adjusting the erosion rate.

From previous studies, we have found that a large inherited component of ${ }^{36} \mathrm{Cl}$ makes dating young alluvium difficult. Some initial depth-profile dating of distal Holocene fans at the NPS Cow Creek Administrative site north of Furnace Creek (CC, fig. 1; table 3) showed that the Holocene alluvium was locally reworked from older (middle? Pleistocene) alluvium (Machette and others, 1999) rather than from fresh bedrock in the Funeral Mountains, about $10 \mathrm{~km}$ to the east. For example, the middle Holocene alluvium on the Old Ghost fan (Stop B3, Machette, Menges, Slate, and others, 2001) has an inherited inventory of ${ }^{36} \mathrm{Cl}$ that would be equivalent to $65 \mathrm{kyr}$ of surface exposure. Similarly, alluvium at 2-m depth in the Salt Pan Vista trench (SPV-3, Machette and others, 1999) contained ${ }^{36} \mathrm{Cl}$ equivalent to $94 \pm 10 \mathrm{kyr}$ of surface exposure, whereas the alluvium was considered to be latest Pleistocene based on geomorphic relations and soil development. With the potential for such large inherited components of ${ }^{36} \mathrm{Cl}$, separating the postdepositional ${ }^{36} \mathrm{Cl}$ inventory from the inherited ${ }^{36} \mathrm{Cl}$ in these young fan deposits is difficult (equivalent to a large noise-to-signal ratio) and causes the calculated uncertainty in depositional age to be so large that the profile age estimates are of little value. Thus, in order to produce useful age estimates, the postdepositional ${ }^{36} \mathrm{Cl}$ inventory of alluvium should at least be of a magnitude comparable to the inherited component.

The analyses from modern sediment on the Trail Canyon and Hanaupah Canyon fans show that the inherited component of ${ }^{36} \mathrm{Cl}$ can be both large and variable, especially from different source areas. The proximal sample from Trail Canyon (DV00-1TC, table 3) had an apparent age of $61 \pm 8 \mathrm{ka}$ (inherited component), whereas the distal sample (DV00-20TC) had an apparent age of $83 \pm 15 \mathrm{ka}$. These large components in modern sediment are rather surprising in that Trail Canyon is a deep canyon with robust erosion and deposition. Conversely, the proximal sample from Hanaupah Canyon (DV00-18HF, table 3) had an apparent age of $46 \pm 2 \mathrm{ka}$ and the distal sample (DV00-19HC) had an apparent age of $38 \pm 4 \mathrm{ka}$, which was the youngest of the four samples analyzed. Interestingly, the modern sediment from Hanaupah Canyon has roughly one-half the apparent age of that being carried down Trail Canyon.

\section{Pedological Considerations in Profile Sampling and Analysis}

We use the best fit between a calculated depth function for the ${ }^{36} \mathrm{Cl}$ inventory and the measured ${ }^{36} \mathrm{Cl}$ profile to determine age of the deposit. We identify the best-fit match by minimizing the sum of chi-squared function $\left(\chi^{2}\right)$ for all of the samples in the profile, as computed from the differences between the calculated and measured values. Uncertainties in the ages were also calculated from the $\chi^{2}$ variation, which is described in more detail herein. The theoretical ${ }^{36} \mathrm{Cl}$ inventories with depth were calculated using the spreadsheet model
"CHLOE" (CHLOrine-36 Exposure age; Phillips and Plummer, 1996), which is based on cosmogenic nuclide production equations (Gosse and Phillips, 2001). We calculate the highenergy cosmic-ray flux from standard exponential attenuation with mass depth; the spallation-production rate is proportional to that flux. This flux distribution is then incorporated in the model as the source term to calculate the epithermal and thermal neutron fluxes using diffusion equations (Phillips and others, 2001). We use the spatial distributions of low-energy neutron fluxes to calculate the ${ }^{36} \mathrm{Cl}$ production by epithermal and thermal neutron absorption, using Phillips and others' (2001) nuclide production parameters and the elevation/ latitude scaling of Lal (1991). Using alternative production parameters (Stone and others, 1996a, 1996b) would give ages that are approximately 15 percent younger.

CHLOE simulates erosion using classical cosmogenicnuclide formulations (for example, see Gosse and Phillips, 2001), which assume that erosion is from the surface. Analogous equations are not commonly used for the case of aggradation because there is no fixed relation between the cosmogenic nuclide concentration of sediment deposited on top of a geological unit and that of the material in the original unit. However, for the materials we are analyzing, this is not an issue because aggradation results from atmospheric dust deposition and infiltration, and the products of the deposition (mainly silt and calcium carbonate) are separated from the clasts being analyzed by sieving and acid leaching. We therefore analyzed none of the material accumulated due to atmospheric deposition, and its cosmogenic nuclide content is thus not a factor in interpreting the data. Some inconsistency remains, however, between the theoretical formulation and the actual nature of the aggradation process because the classical equations, when used for aggradation, treat the process entirely as deposition on the surface. This is true for part of the actual atmospheric deposition (the Av horizon) but not for the pedogenic calcite and silt that precipitate and translocate (respectively) in the soil. This may affect the outcome of the curve-fitting analysis, but probably not to a large extent relative to other uncertainties in the analysis.

The amount of net-surface aggradation or erosion also can be estimated independently from measurements of soil properties and geological observations. Secondary accumulation products add to the original soil mass, thereby diluting the relative concentration of the original granular material (mainly sand and gravel). In some of the soils we excavated, a combination of eolian silt, clay, and salt had infiltrated to at least a depth of one meter. These additions result in a net upward growth of the original soil surface owing to progressive volumetric expansion (fig. 5, C and D). Upward growth occurs because this is the direction of least resistance, whereas confining pressure resists lateral expansion. Although we selected the least-eroded surfaces possible, the presence of thinned or stripped Av horizons or slightly irregular surface morphology suggests that minor amounts of erosion have occurred at some sites. To better constrain the models of the isotopic data, we used geologic and geomorphic observations to estimate the 
amount of surface erosion and(or) aggradation and used these preliminary ${ }^{36} \mathrm{Cl}$ depth-profile ages to calculate maximum, minimum, and preferred surface-erosion rates in millimeters per thousand years, where positive values indicate aggradation and negative values indicate erosion. The preferred rates range from $+2 \mathrm{~mm} / \mathrm{kyr}(20 \mathrm{~cm}$ in $100 \mathrm{kyr})$ to $-1 \mathrm{~mm} / \mathrm{kyr}(-10 \mathrm{~cm}$ in $100 \mathrm{kyr})$ and average about $+1 \mathrm{~mm} / \mathrm{kyr}$ (10-cm aggradation in $100 \mathrm{kyr}$ ) for all the sites we sampled. Table A8 in the Appendixes shows estimated surface erosion or aggradation rates for the depth-profile sampling sites.

\section{Modeling of Profile Age and Uncertainties}

Cosmogenic ${ }^{36} \mathrm{Cl}$ is principally produced in rocks and soils by three reactions (fig. 9): high-energy spallation of potassium and calcium and low-energy neutron absorption by chlorine (Gosse and Phillips, 2001). The rate of production at any depth below the surface by the first two reactions depends on the concentrations of the target elements and the high-energy cosmic-ray flux at that depth. The high-energy cosmic-ray flux decreases exponentially through the cumulative mass (soil and rock) traversed by the cosmic rays. Thus, production by these reactions can be calculated on the basis of measurement of the bulk density through the depth profile and the concentrations of potassium and calcium in the sampled material.

Nuclide production by low-energy neutron absorption depends on the low-energy (thermal and epithermal) neutron fluxes and the $\mathrm{Cl}$ concentration. Low-energy neutrons are produced by gradual deceleration of the high-energy flux, and they can diffuse significant distances while in the epithermal and thermal energy ranges. The characteristics of the lowenergy flux thus depend on bulk properties of the medium (Phillips and others, 2001). Therefore, CHLOE is designed to use the average bulk chemical composition of the soil profile to compute the depth distribution of the low-energy neutron fluxes. The computed neutron fluxes and the chlorine concentrations measured at each sampled depth are then used to calculate the ${ }^{36} \mathrm{Cl}$ production rate. In addition to production by the nucleonic component of the cosmic radiation, CHLOE also computes ${ }^{36} \mathrm{Cl}$ production due to primary and secondary effects of the cosmic-ray muon flux, using approaches analogous to those described above. Muons are secondary cosmicray particles, produced during propagation of the cosmic-ray cascade through the atmosphere, that interact with several common elements in rocks to produce ${ }^{36} \mathrm{Cl}$. However, the rate of production by muons is typically less than 10 percent of that by spallation and low-energy neutron absorption; thus, muon reactions are generally of secondary significance for surface-exposure dating (Stone and others, 1998).

The profile age and age uncertainty were calculated by $\chi^{2}$ fitting (Bevington and Robinson, 1992) of the ${ }^{36} \mathrm{Cl}$ concentration data from the various depths to the ${ }^{36} \mathrm{Cl}$ distribution modeled by CHLOE. The sum of chi-squared
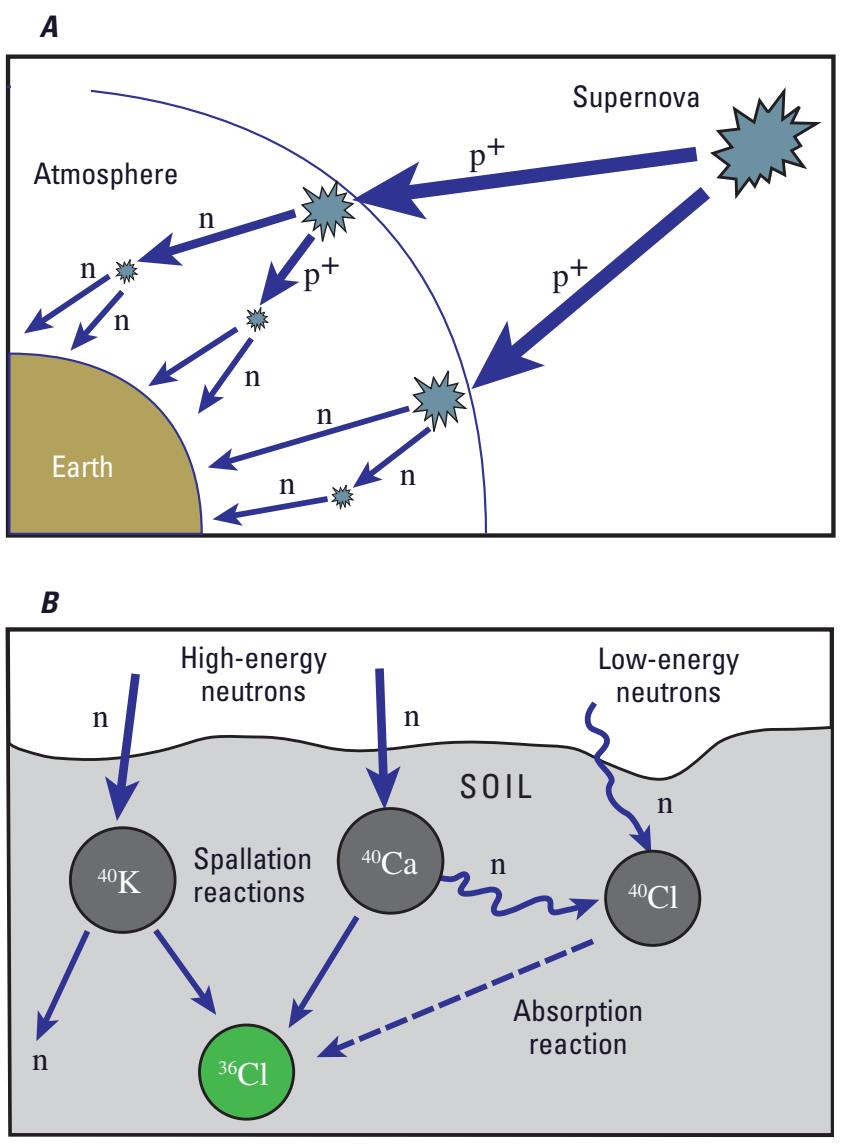

Figure 9. Schematic diagrams showing (A) production of neutrons $(n)$ from cosmic ray protons $(p+)$ entering the Earth's atmosphere, and (B) production of ${ }^{36} \mathrm{Cl}$ in soil (or rock) materials due to spallation reactions on ${ }^{40} \mathrm{~K}$ and ${ }^{40} \mathrm{Ca}$ and low-energy neutron absorption by ${ }^{35} \mathrm{Cl}$ (see Gosse and Phillips, 2001, for more details). The solid arrows indicate high-energy spallation reactions and the dashed arrow indicates the lowenergy neutron absorption reaction.

function $\left(\chi^{2}\right)$ was calculated for each age-erosion pair as follows:

$$
\chi^{2}=\sum_{i=1}^{n} \frac{\left(O_{i}-M_{i}\right)^{2}}{S_{i}^{2}}
$$

where $O_{i}$ is the observed ${ }^{36} \mathrm{Cl}$ concentration at each depth interval $(i), M_{i}$ is the modeled value at the same depth, and $n$ is the number of concentration measurements. $S_{i}$ is the standard deviation associated with the $i^{\text {th }}$ data point defined as follows:

$$
S_{i}=S_{i, 36}+S_{\text {inheritance }}+S_{\text {other }}
$$

where $S_{i, 36}$ is the standard deviation from the ${ }^{36} \mathrm{Cl}$ analytical measurement, $S_{\text {inheritance }}$ is the contribution to the standard deviation attributed to variability in the inherited ${ }^{36} \mathrm{Cl}$ concentration, and $S_{\text {other }}$ is the contribution from other sources of variability, principally analytical uncertainties in 
the chemical analyses, bulk densities, and other parameters, combined with uncertainties in the ${ }^{36} \mathrm{Cl}$ production parameters. $S_{i, 36}$ was taken directly from the AMS analyses. $S_{\text {inheritance }}$ was estimated from a ${ }^{36} \mathrm{Cl}$ depth-profile measured on a radiocarbon-dated Lake Lahontan shoreline deposit (Kurth, 2003). Chi-squared $\left(\chi^{2}\right)$ fitting of the profile yielded an age uncertainty that was 3 percent larger than theoretically calculated, assuming all other sources of variation were accounted for adequately. This enhancement of the $\chi^{2}$ can presumably be attributed to variability of the inherited component that had not otherwise been taken into account. $S_{\text {other }}$ was estimated based on an empirical comparison of ${ }^{36} \mathrm{Cl}$ ages with independently constrained ages for 30 surficial rock samples (Phillips and others, 2001) and was assigned a value of 6 percent. For each profile we also report the reduced sum $\chi^{2}\left(\chi_{v}^{2}\right)$ which is the sum of $\chi^{2}$, as given above, divided by $n$, the number of samples in the profile. The magnitude of $\chi^{2}{ }_{v}$ is a measure of the quality of fit of the data to the model. In general, for laboratory systems in which the model can be assured to provide a complete description, a $\chi^{2}$ of less than one is considered a satisfactory fit (Bevington and Robinson, 1992). When dealing with environmental measurements for which the model may be incomplete, somewhat larger values of $\chi_{v}^{2}$ are often considered acceptable.

CHLOE produces calculations of ${ }^{36} \mathrm{Cl}$ concentrations at the sampled profile depths, subject to variation of three adjustable parameters: the profile inheritance $\left(t_{p}\right)$, the profile-deposition age $\left(t_{d}\right)$ and the rate of surface aggradation/erosion $\left(\sum\right)$. The model output was fairly sensitive to $t_{p}$ and $\left(t_{d}\right)$ but relatively insensitive to $\sum$. The fitting of calculated ${ }^{36} \mathrm{Cl}$ concentrations to data was therefore restricted to aggradation/erosion rates $\left(\sum\right)$ limited between upper and lower bounds estimated for each site on the basis of soil parameters and geological observations (as previously described), although the aggradation/ erosion rate could potentially be used as a fitting parameter. In most cases, however, the weak sensitivity of the calculated ${ }^{36} \mathrm{Cl}$ concentration to aggradation/erosion caused insignificant variation of the sum of $\chi^{2}$ across the prescribed range of $\sum$. In those cases in which the calculated ${ }^{36} \mathrm{Cl}$ concentration was relatively insensitive to the aggradation/erosion rate, the midpoint of the range of $\sum$ ( $B$, fig. 10) was used to calculate the best-estimate deposition age (that is, $\sum$ was used as a fixed, rather than fitting, parameter). In some cases (profiles S11, S14, S15, S16, and S17), there was a significant minimum in the sum of $\chi^{2}$ within the prescribed range for $\sum$, and in these cases this minimum was used to compute the best-estimate deposition age. Use of the alternative criterion (midpoint of $\sum$ range) would have resulted in little difference in the best estimates of deposition age. The result of this pattern of insensitivity was that the variation in $\sum$ was a significant factor in estimation of the uncertainty of the best-fit deposition age but was not significant in estimating its actual value.

The first step in finding the optimal profile fitting was to locate the minimum in the sum of $\chi^{2}$ within the $t_{d}$ versus $t_{p}$ parameter space. Next, using the value of $t_{p}$ thus obtained, the sum of $\chi^{2}$ was calculated in the $t_{d}$ versus $\sum^{p}$ parameter space
Contours of $\chi^{2}$ calculated from mismatch of predicted and measured values. Values of contours increase concentrically outward

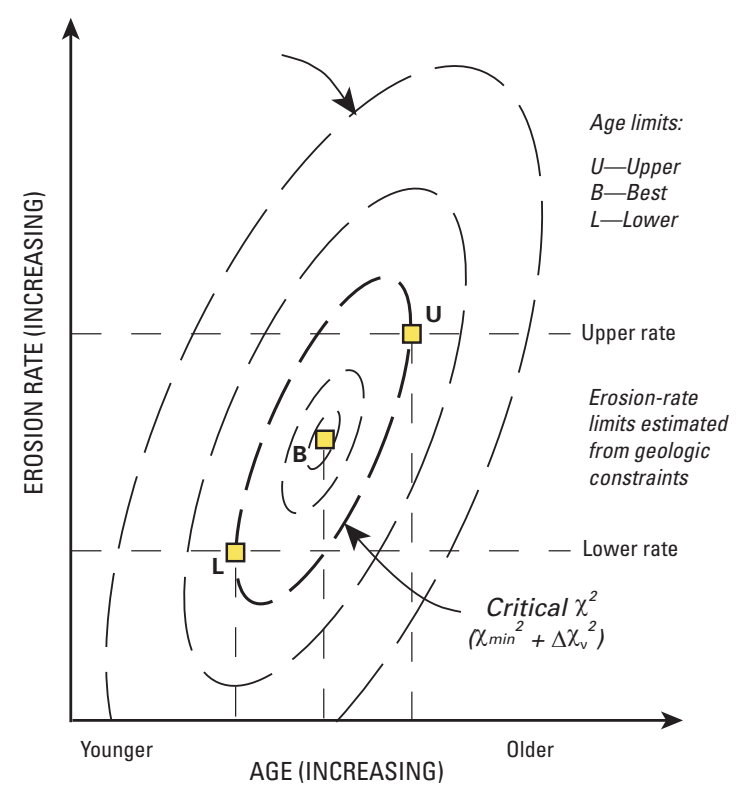

Figure 10. Plot of sum-of-chi-squared $\left(\chi^{2}\right)$ values as a function of assumed erosion rate and age. The best age estimate $(B)$ is defined by the minimum $\chi^{2}$ value. The figure illustrates how the upper $(U)$ and lower $(L)$ bounds of the one-sigma age uncertainty limits are determined based on the intersections of the geologically estimated erosion limits and the critical $\chi^{2}$ value.

and the minimum identified. If necessary, these steps were iterated so as to ensure that the minimum sum of $\chi^{2}$ for the three-parameter space $\left(t_{d}-t_{p}-\Sigma\right)$ was found. The array of sum of $\chi^{2}$ values generated in this way was then contoured in the $t_{d}$ versus $\sum$ parameter space, as shown in figure 10 . The best age estimate $(B)$ corresponds to the minimum value of the sum of $\chi^{2}$. One standard-deviation uncertainty bounds were estimated from the upper ( $U$, fig. 10) and lower ( $L$, fig. 10) age limits of the $\chi^{2}{ }_{\text {min }}+\Delta \chi^{2}{ }_{v}$ contour in the age-erosion parameter space. $\chi^{2}{ }_{\min }$ is the minimum value of the calculated sum of $\chi^{2}$ within the parameter space, and $\Delta \chi^{2}$ is the critical value of the change in sum of $\chi^{2}$ for a specified level of confidence and number of fitted parameters ( $v$ ) (for example, Davis, 2002, table A.4). For our problem, the appropriate level of confidence is 68.3 percent (corresponding to one standard deviation uncertainty) and two fitted parameters $\left(t_{d}\right.$ and $t_{\text {inheritance }}$, giving a $\Delta \chi^{2}{ }_{v}$ of 2.30. The approach to uncertainty estimation described above is both detailed and comprehensive; potential systematic as well as random sources of uncertainty are included. Model accuracy is explicitly calculated, based on the fit of multiple samples within a single profile, as opposed to a single ${ }^{36} \mathrm{Cl}$ depth-profile age determination for which model error can only be estimated. We believe that the overall uncertainty 
bounds calculated using this approach are conservative and are likely to overestimate rather than underestimate the actual uncertainties.

In table 4, we show the best-estimate ages with uncertainty bounds, the inheritance age (note that this reflects inheritance at the time of sampling, not deposition), and the reduced sum of $\chi^{2}$. The complete data set used in the CHLOE profile modeling, the results, and depth profile plots are shown in table A9 (Excel spreadsheet), whereas the range of aggradation/erosion rates employed in the analysis are shown in table A8. Note that 12 of the 13 age profiles yield $\chi_{v}^{2}$ values of less than 1 (table 4), and a significant proportion of the ages have excellent fits as reflected by $\chi_{v}^{2}$ values of less than 0.3 . These data show that the CHLOE modeling approach simulates the cosmogenic-nuclide-accumulation processes and supports the likelihood of a conservative bias in the uncertainty analysis.

The estimated uncertainty bounds vary widely and commonly are strongly asymmetric. The width of the uncertainty bounds typically depend on the assigned range of aggradation/ erosion rates, with wider bounds being associated with larger ranges of rates. The asymmetry is especially pronounced for older samples that have significant erosion within the permitted range of surficial mass fluxes. This is because the inferred deposition age is much more sensitive to erosional mass fluxes than to aggradational ones (erosion actually removes ${ }^{36} \mathrm{Cl}$ atoms, whereas the effect of aggradation is only to mildly increase the mass shielding). Net aggradation is obvious in the high calcium carbonate and (or) silt contents of older desert soils; that is, ones that have been subject to long periods of soil formation in arid to semiarid environments (Machette, 1985; Birkeland, 1999). This characteristic can be used to advantage in ${ }^{36} \mathrm{Cl}$ profile dating by selectively sampling soils that have undergone net aggradation rather than erosion and thus will yield more precise profile ages. Careful study of soil characteristics to (1) identify profiles that are dominated by aggradation (such as in Death Valley) and (2) quantify the limits on the possible range of soil net-mass change with time could be of great utility in obtaining more precise ${ }^{36} \mathrm{Cl}$ profile ages.

\section{Implications of Results for Cosmogenic-Nuclide Profile Dating Methodology}

This study has produced a larger number of cosmogenicnuclide profiles from alluvial surfaces than most previous studies and has used a somewhat different methodology. Some methodological implications can be drawn from these. The most prominent is that, in general, the fundamental assumptions of cosmogenic-nuclide profile dating appear to be confirmed by the field data, at least for the relatively arid environment of Death Valley. As mentioned above, 12 out of 13 samples yielded $\chi_{v}^{2}$ values less than one, and 6 out of the 13 values less than 0.3 . These very good fits indicate that the model adequately describes the processes that control ${ }^{36} \mathrm{Cl}$

Table 4. ${ }^{36} \mathrm{Cl}$ cosmogenic-nuclide age estimates for alluvial units, modern alluvium, and relict boulders in Death Valley National Park, California.

[Site data and erosion rates are shown in tables A7 and A8, respectively. sed, modern stream alluvium; rock, metamorphic quartzite boulder; NA, not applicable]

\begin{tabular}{lcccc}
\hline \multirow{2}{*}{$\begin{array}{r}\text { Profile or } \\
\text { sample no. }\end{array}$} & Map & \multicolumn{2}{c}{$\begin{array}{c}\text { Best estimate of age (ka) } \\
\text { and error limits }\end{array}$} & $\begin{array}{c}\chi_{\text {v }}{ }^{2} \text { (reduced } \\
\text { sum of } \chi^{2} \text { ) }\end{array}$ \\
\cline { 3 - 4 } unit & Qay & $0.8(+8.4 /-8.6)$ & $94 \pm 10$ & 0.86 \\
DV00-S3 & Qaio & $171(+74 /-21)$ & $38 \pm 6$ & 0.16 \\
DV00-S5 & Qlm & $130(+75 /-39)$ & $45 \pm 17$ & 0.97 \\
DV00-S6 & Qai & $47(+20 /-17)$ & $97 \pm 12$ & 0.22 \\
DV00-S7 & Qai & $84(+19 /-25)$ & $83 \pm 12$ & 0.85 \\
DV00-S8 & Qai & $39(+19 /-15)$ & $38 \pm 7$ & 0.11 \\
DV00-S9 & Qai & $72(+24 /-20)$ & $37 \pm 7$ & 0.62 \\
DV00-S11 & Qai & $96(+13 /-16)$ & $23 \pm 6$ & 0.27 \\
DV00-S12 & Qai & $66(+22 /-14)$ & $43 \pm 7$ & 0.86 \\
DV00-S14 & Qai & $65(+16 /-10)$ & $59 \pm 8$ & 0.75 \\
DV00-S15 & Qai & $55(+13 /-16)$ & $63 \pm 8$ & 0.12 \\
DV00-S16 & Qai & $97(+37 /-16)$ & $72 \pm 17$ & 1.37 \\
DV00-S17 & Qai & $79(+34 /-21)$ & $62 \pm 9$ & 0.18 \\
DV00-1TC & Qal (sed) & NA & $61 \pm 8$ & NA \\
DV00-3TC & Qai (rock) & $102( \pm 7)$ & NA & NA \\
DV00-5HC & Qai (rock) & $118( \pm 11)$ & NA & NA \\
DV00-18HF & Qal (sed) & NA & $38 \pm 4$ & NA \\
DV00-19HC & Qal (sed) & NA & $46 \pm 2$ & NA \\
DV00-20TC & Qal (sed) & NA & $83 \pm 15$ & NA \\
\hline
\end{tabular}

\$This profile was dated by Machette and others (1999) as part of a seismic hazards study of the Cow Creek area. It is included in this table because it showed an extremely large component of inherited chlorine. 
accumulation in soils on alluvial deposits and encourages additional applications.

One aspect of the results that is not quite so favorable is the relatively large uncertainty bounds on the age estimates. These are significantly larger than would typically be obtained, for example, from single ${ }^{36} \mathrm{Cl}$ measurements on boulder surfaces. However, this apparent large uncertainty is largely derived from a more rigorous treatment of systematic uncertainty than is usually performed for boulder measurements. The systematic uncertainty is currently particularly large for ${ }^{36} \mathrm{Cl}$ dating because of uncertainties related to the production rate parameters (Gosse and Phillips, 2001). Future improvements in the accuracy of these parameters should correspondingly shrink the uncertainty bounds of ${ }^{36} \mathrm{Cl}$ depth-profile ages.

The largest nonsystematic contribution to uncertainty arises from surface erosion because erosion can significantly affect calculated ages, and the magnitude of surface modification is difficult to constrain. At first glance, it might appear that surface-exposure dating of boulders (rock) would be inherently much more accurate and precise than ${ }^{36} \mathrm{Cl}$ profile dating because rock surfaces typically erode much more slowly than soils. However, in arid and semiarid environments such as Death Valley, investigators can take advantage of the typical eolian inflation of soils to obtain more precise profile ages than otherwise would be possible due to the lower sensitivity of profile ages to inflation than erosion. Fortunately, the fine texture (or soluble nature) of the additions to arid/semiarid soils allows the accreted component to be easily separated from the alluvial component.

This study has used a more formalized statistical treatment of parameter and uncertainty evaluation than most previous similar studies. The procedure has the advantages of a fairly rigorous evaluation of both systematic uncertainties and uncertainties attributable to the fit of the data to the model. In addition, it provides a quantitative evaluation of the adequacy of the model. It also incorporates independent geological observations (in terms of estimation of erosion/aggradation rates) to further constrain the final age estimate.

\section{Stratigraphic and Chronologic Interpretations}

Since we knew that some alluvial-fan deposits in Death Valley have large inventories of inherited ${ }^{36} \mathrm{Cl}$ (Machette and others, 1999) and thus could induce large age uncertainties for Holocene and latest Pleistocene age fans, we targeted the intermediate-age Pleistocene alluvial fans (unit Qai) for extensive ${ }^{36} \mathrm{Cl}$ depth-profile dating. Unit Qai, which is part of Hunt's broad Q2 gravel unit (Hunt and Mabey, 1966), is among the most extensive of the Quaternary surfaces in Death Valley and records significant amounts of both vertical and lateral offset by some of the active faults in the eastern side of the valley. Thus, determining the ages of Qai alluvial fans would provide valuable information on fault slip rates and rates of vertical uplift associated with localized compression along and between faults. In addition to dating the Qai surfaces, we sampled one depth profile on an older element of Qai (informal unit Qaio) from Trail Canyon, suspecting it was older than most Qai intemediate age (Qai) alluvial surfaces on the basis of its limited preservation and degraded geomorphic expression.

Twelve ${ }^{36} \mathrm{Cl}$ depth-profile dates were generated from our studies in Death Valley. The bulk of the dates are from alluvial unit Qai (fig. 11), but we dated one profile from lacustrine gravel (unit Qlm) and one older alluvial gravel (unit Qaio). Alluvial deposits older than unit Qai, such as unit Qao, generally were not accessible within the limitations imposed by our National Park Service sampling permit, although Dühnforth and others (2007) recently dated a variety of middle and early Pleistocene deposits in Death Valley, south of our study areas. All of the ${ }^{36} \mathrm{Cl}$ depth-profile dates are listed in table 5 and plotted on figure 12, according to sampled unit. Conversely, the entire dataset used in the CHLOE Excel spreadsheet is provided as table A9 (Excel spreadsheet).

Our recent mapping of the surficial geology in central Death Valley (Slate and others, in press) shows that the Qai fans postdate high-level shoreline and delta-complex gravels (Qlm) associated with the last deep-water cycle of Lake Manly (fig. 11). The lake was associated with marine oxygen-isotope stage (MIS) 6 and clearly predates stage 2 and 4(?) lakes, which appear to a be of a lesser extent in Death Valley (see Anderson and Wells, 2003). ${ }^{36} \mathrm{Cl}$ depth-profile dating of the Lake Manly lacustrine gravels (S5, unit Qlm) yielded an age of $130 \mathrm{ka}$, whereas the subjacent alluvium that forms various Qai surfaces at lower elevations ranged from about $97 \mathrm{ka}$ to $39 \mathrm{ka}$ (fig. 12), indicating deposition over a long portion of the late Pleistocene. Recent terrestrial cosmogenic-nuclide dating studies at other arid to semiarid sites in the southwestern Great Basin show that many of the alluvial fans covering large areas were deposited 75-60 ka, during MIS stage 4 (Reheis and others, 1996; Gosse and others, 2003, 2004).

Prior surface-exposure dating of large boulders on the Hanaupah Canyon fan by Nishiizumi and others (1993, their table 7) gave ages of $117 \mathrm{ka}$ to greater than $314 \mathrm{ka}$. The $117 \pm 4$ ka age is from their unit Q3a, which appears to be equivalent to our alluvial unit Qai from which we obtained a nearly identical surface exposure age of $118 \pm 11 \mathrm{ka}$ (DV00-5HC, table 4). The boulder we sampled from the Trail Canyon fan (DV00-3TC, table 4) is also from the Qai surface and yielded an age of $102 \pm 7$ ka. Thus, three boulders from mapped Qai surfaces yielded surface-exposure ages of $102 \mathrm{ka}, 117 \mathrm{ka}$, and $118 \mathrm{ka}$, which are uncorrected for any inherited age components and thus might be maximum age limits for Qai. The next higher (older) surface on the Trail Canyon fan is Qaio (an older phase of unit Qai, fig. 11), which is more highly dissected and less continuous than Qai alluvium. A depth profile from Qaio alluvium at site S2 yielded an age of 171 $(+74 /-21) \mathrm{ka}$, which is the oldest age we obtained from all the depth profiles. This ${ }^{36} \mathrm{Cl}$ depth-profile age suggests that Qaoi probably ranges from 200 to $150 \mathrm{ka}$ and predates the culmination of the penultimate glaciation (MIS 6). 


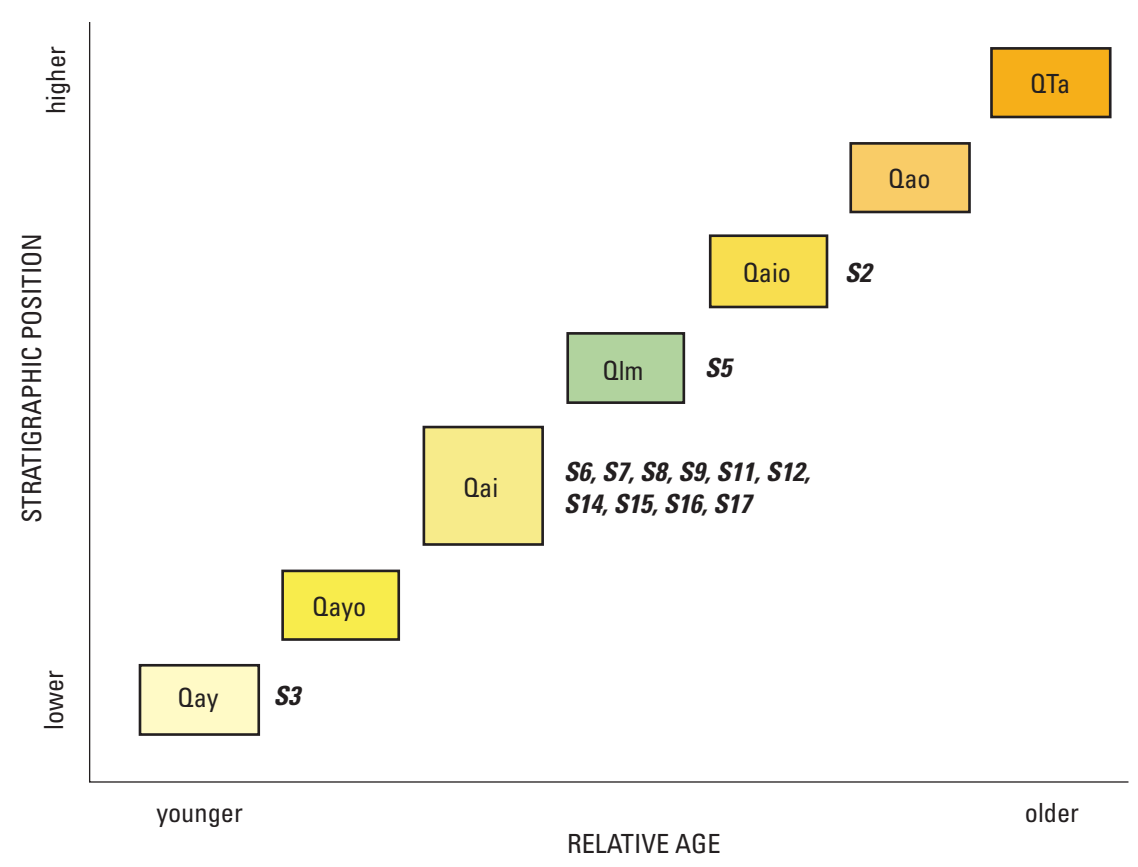

Figure 11. Schematic diagram showing surficial geologic units encountered during ${ }^{36} \mathrm{Cl}$ depth-profile dating in Death Valley. Inset and topographic relations indicate stratigraphic position and relative age. Geologic units are shown in figure 3 for the Hanaupah Canyon fan. Sampling sites (that is, S3) are shown for each unit and listed in tables 4 and $\mathrm{A} 1$.

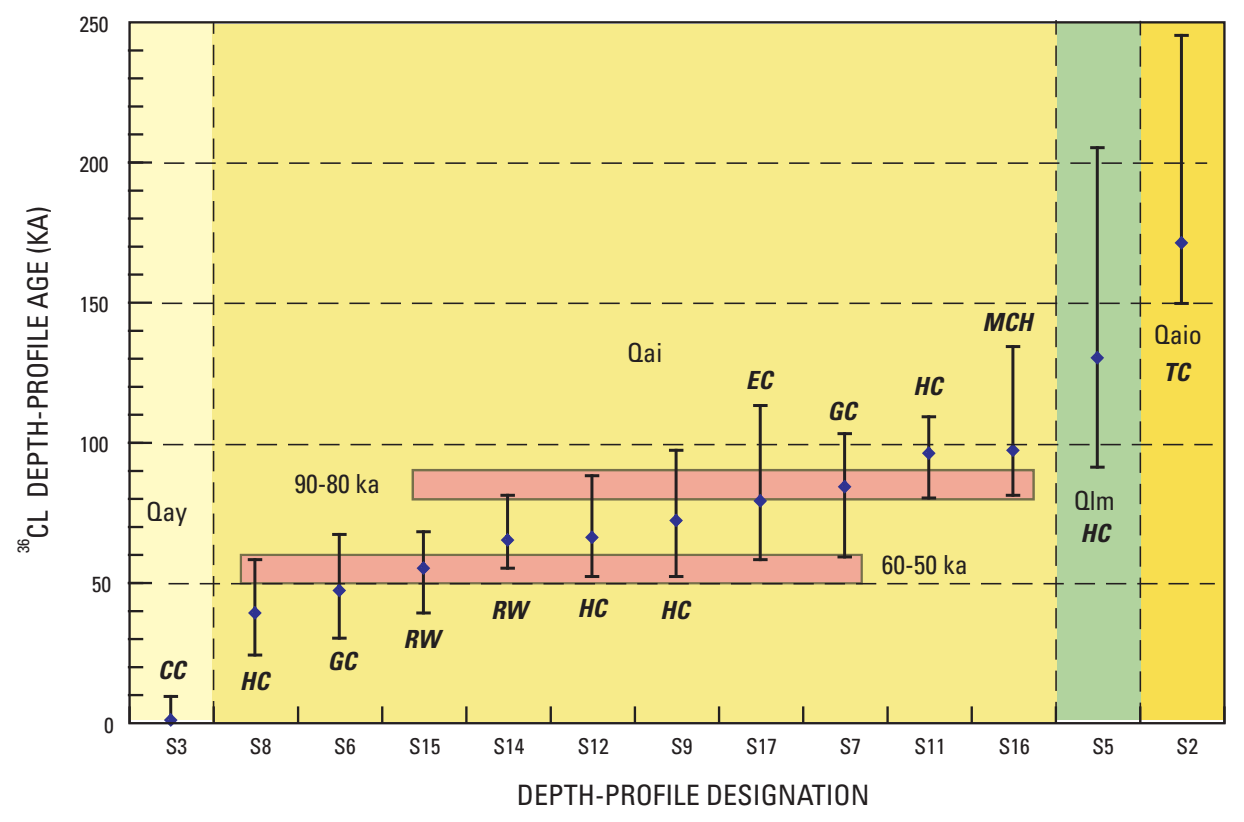

Figure 12. Plot of ${ }^{36} \mathrm{Cl}$ depth-profile ages (table 5) for four surficial geologic units in Death Valley. Sampled profiles are listed on horizontal axis in terms of increasing age. Bars indicate one sigma error uncertainty. Horizontal boxes indicate two permissible age ranges for all of the Qai samples compared to a more general age range of $100-40 \mathrm{ka}$. Geologic units are same colors as shown in figure 11. Letter symbols indicate sampled area: CC, Cow Creek; HC, Hanaupah Canyon; GC, Galena Canyon; RW, Redwall Canyon (Mile 22 fan); EC, Echo Canyon; MCH, Mustard Canyon hills; TC, Trail Canyon. Depth-profile data and age calculations are included in table A9 (on CD-ROM). 
Table 5. Suggested chronology for middle to late Quaternary surficial deposits in Death Valley based on new and published cosmogenic nuclide ages.

\begin{tabular}{|c|c|c|c|c|c|c|c|}
\hline \multirow{2}{*}{$\begin{array}{l}\text { Map unit and cor- } \\
\text { relative marine oxygen } \\
\text { isotope stage (MIS) }\end{array}$} & \multicolumn{2}{|c|}{$\begin{array}{l}\text { Surface-exposure age } \\
\text { (boulders) }\end{array}$} & \multicolumn{4}{|c|}{$\begin{array}{l}\text { Depth-profile age (ka) versus } \\
\text { erosion rate }\end{array}$} & \multirow{2}{*}{$\begin{array}{l}\text { Probable age } \\
\text { range for } \\
\text { map unit } \\
\text { (average age) }\end{array}$} \\
\hline & Site & Age & Site & $\begin{array}{l}\text { Min. } \\
\text { rate }\end{array}$ & $\begin{array}{l}\text { Max. } \\
\text { rate }\end{array}$ & $\begin{array}{l}\text { Best } \\
\text { age }\end{array}$ & \\
\hline Qay (MIS 2) & & & S3 & -7.8 & 9.2 & $0.8 \neq$ & $12-30 ? \mathrm{ka}$ \\
\hline \multirow[t]{10}{*}{ Qai (MIS 3-5) } & $5 \mathrm{HC}$ & $118 \pm 11 \mathrm{ka}$ & S6 & 30 & 67 & 47 & 40-100 ka \\
\hline & Q3a* & $117 \pm 4 \mathrm{ka}$ & S7 & 59 & 103 & 84 & (70 ka) \\
\hline & & & S8 & 24 & 58 & 39 & \\
\hline & & & S9 & 52 & 96 & 72 & \\
\hline & & & S11 & 80 & 109 & 96 & \\
\hline & & & $\mathrm{S} 12$ & 52 & 88 & 66 & \\
\hline & & & S14 & 55 & 81 & 65 & \\
\hline & & & S15 & 39 & 68 & 55 & \\
\hline & & & S16 & 81 & 60 & 97 & \\
\hline & & & S17 & 58 & 113 & 79 & \\
\hline Qlm (MIS 6) & & & S5 & 91 & 205 & 130 & $130-180 \mathrm{ka}$ \\
\hline Qaio (MIS 6-7) & $3 \mathrm{TC}$ & $102 \pm 7 \mathrm{ka}$ & S2 & 150 & 245 & 171 & $150-220 \mathrm{ka}$ \\
\hline Qao (MIS 8+) & Q2a* & $>260 \pm 9 \mathrm{ka}$ & & & & & $>260 \mathrm{ka}$ \\
\hline $\begin{array}{l}\text { QTa (early Quat. to } \\
\text { Pliocene) }\end{array}$ & Q1b* & $>314 \pm 22 \mathrm{ka}$ & & & & & Unknown \\
\hline
\end{tabular}

*Ages from Nishiizumi and others, 1993.

$\$ 0.8 \mathrm{ka}$ age is too young, probably owing to large inherited component ( $94 \pm 10 \mathrm{ka}$; see table 4 , DV98-S3).

Nishiizumi and others' (1993) ages of greater than $260 \mathrm{ka}$ and greater than $314 \mathrm{ka}$ are from alluvial units that are equivalent to and older than our unit Qao, which was not sampled for ${ }^{36} \mathrm{Cl}$ depth-profile dating. Erosion of the alluvial surfaces from which they sampled boulders suggests that the latter surfaceexposure ages are minimum estimates for depositional age of the underlying alluvium.

Ten individual ${ }^{36} \mathrm{Cl}$ depth-profile dates were obtained from alluvial unit Qai (figs. 11 and 12 and table 5). Four of these dates are from Hanaupah Canyon fan (S8, S9, S11, S12), whereas another four profiles (S4-S17) came from faulted Qai fans on the east side of Death Valley (see following discussion of "Rates of Fault Slip and Uplift"), and two profiles (S6, S7) came from the Galena Canyon fan (table A3).

The ${ }^{36} \mathrm{Cl}$ depth-profile dates from Qai deposits on the Galena Canyon fan vary even though the surface morphology at the two sampling sites appeared similar. Depth profile S7 yielded an age of $84 \mathrm{ka}$, whereas the depth profile from nearby site $\mathrm{S} 6$ yielded $47 \mathrm{ka}$, one of the youngest ages determined by our dating (table 5). The maximum age for S6 overlaps with the minimum for $\mathrm{S} 7$ at the 1 sigma level. Thus, if these two morphologically similar surfaces are part of the same deposit, it would be in the range of 59-67 ka. Conversely, although we considered both sites to be Qai alluvium, they may be from younger and older phases. The soil at sampling site S7 (table A3) was slightly thicker than at S6 and contained a silica-cemented Bkyq horizon at $21-58 \mathrm{~cm}$, suggesting that profile $\mathrm{S} 7$ formed for a longer time than profile S6. Nevertheless, the ${ }^{36} \mathrm{Cl}$ depth-profile ages for both sites fit within the general range of 40-100 ka (table 5) for entire set of ${ }^{36} \mathrm{Cl}$ depth-profile-dated Qai alluvium (fig. 12).

The results from the Hanaupah Canyon fan show a similar range of ages but do not coincide well with local geomorphic relations. Site $\mathrm{S} 9$ is from a younger (unmapped) phase of Qai that is about 10 meters below the grade of the adjacent Hanaupah Canyon fan (fig. 3) and has a fresher morphology than most Qai surfaces; thus, we suspected that it is younger than the main fan surface. Depth profile $S 9$ yielded a surprisingly old age of $72 \mathrm{ka}$, suggesting that the surface morphology might have been refreshed by overflow without significant erosion of the underlying Qai alluvium.

Sites S8, S10, S12, and S11 (located from east to west, respectively) were sampled from backhoe pits along the Hanaupah Canyon Road. Sites S8, S10 (not analyzed), and S12 were chosen for their close proximity on the distal (eastern) end of the main fan surface, whereas S11 was 
located several kilometers upslope on the proximal (western) portion of the fan surface. Sample S8 was excavated on the top of a narrow ridge, whereas S12 is placed on an intact Qai fan surface. S8 yielded the youngest age (39 ka) from unit Qai and, in retrospect, is probably from an eroded profile. Conversely, S12 yielded a depth-profile age of $66 \mathrm{ka}$. Sample $\mathrm{S} 11$ yielded a relatively old age of $96 \mathrm{ka}$ (table 5). Thus, the range of ${ }^{36} \mathrm{Cl}$ depth-profile ages for the four samples on Hanaupah Canyon fan is $39 \mathrm{ka}$ (eroded) to $96 \mathrm{ka}$, which spans most of MIS 3, 4, and 5 .

The data permit an alternate interpretation of two phases of deposition of the Qai alluvium as suggested at the Galena Canyon sites (S6 and S7). In figure 12, we have drawn two time range boxes that permissibly include all of the ages for the Qai alluvium sampled on the west-side fans. An older episode of deposition may have occurred from 90 to $80 \mathrm{ka}$, before MIS stage 4, whereas a younger episode of deposition postdated MIS 4, from about 60 to $50 \mathrm{ka}$. In this interpretation, the deposition of Qai alluvium occurs in rather short episodes before and after formation of an MIS 4 lake in Death Valley.

Four additional ${ }^{36} \mathrm{Cl}$ depth-profile ages (S14-S17) were determined for alluvium that is correlative to Qai but located on the eastern side of Death Valley. These ages ranged from 55 to $97 \mathrm{ka}$, well within the range defined by the dating of Qai on the Galena and Hanaupah Canyon fans. The details for profiles S14-S17 are discussed separately herein because each site has been affected by tectonics and thus records a unique history of uplift or offset.

In summary, ${ }^{36} \mathrm{Cl}$ depth-profile dating of alluvial unit Qai generally indicates deposition from about as early as $100 \mathrm{ka}$ to as late as $40 \mathrm{ka}$, although the older end of this time range is generally associated with eroded or deformed sites. An alternative interpretation is that alluvial unit Qai was deposited in two discrete episodes: from 90 to $80 \mathrm{ka}$ and from 60 to $50 \mathrm{ka}$, before and after MIS 4 (respectively). Without an intermediate-age unit, such as MIS 4 lake deposits, we can neither prove nor disprove that Qai was deposited in two discrete intervals or over a longer range of time.

The next stratigraphically older unit is lacustrine gravels deposited during the last deep-water cycle of Lake Manly, which is dated at $130 \mathrm{ka}$ (culmination of MIS 6). A single ${ }^{36} \mathrm{Cl}$ depth profile from alluvial unit Qaio (older phase of Qai) on the Trail Canyon fan yielded our oldest date (171 ka), which indicates deposition of older alluvial fan gravels during the earlier part of MIS 6. Finally, surface-exposure dating of large boulders on various west-side fans (Nishiizumi and others, 1993; Dühnforth and others, 2007) using cosmogenic ${ }^{10} \mathrm{Be}$ and ${ }^{26} \mathrm{~A} 1$ have dated deposits equivalent to the Q2 and QTg1 gravels of Hunt (Hunt and Mabey, 1966) that range widely (60-860 ka) and have a strong inherited component, commonly equivalent 60-240 kyr.

\section{Implications for Lake Manly}

\section{Lake Manly}

Blackwelder $(1933,1954)$ firmly established the size and importance of Pleistocene Lake Manly, but little was known about the timing of highstands until the advent of radiocarbon and other numerical dating techniques. As a result of our ${ }^{36} \mathrm{Cl}$ depth-profile dating, it appears that the lacustrine delta complex found on the Hanaupah Canyon alluvial fan (site S5) was abandoned at about $130 \mathrm{ka}(+75 /-39 \mathrm{ka})$. This date overlaps with the 186-119-ka perennial lake (MIS 6) inferred by Lowenstein and others (1999) from cores retrieved at Badwater, due east of the Hanaupah Canyon fan. Ostracodes retrieved from that same core have been interpreted to demonstrate that the most dilute lake in Death Valley existed at around $154 \mathrm{ka}$ (Forester and others, 2005). Our ${ }^{36} \mathrm{Cl}$ depthprofile ages are consistent with these interpretations from the Badwater core and deposition of the delta complex during the later part of marine oxygen-isotope stage (MIS) 6. These lacustrine deposits are at an altitude of about +30 meters asl, which relates to a lake with a maximum depth of about 115 meters based on the present topography. (Note: the true depth of the lake is difficult to determine owing to post130-ka deposition, possible subsidence owing to movement along the Black Mountains fault zone, and possible far-field down-dropping of the entire Hanaupah Canyon fan as part of the larger Death Valley graben system.) Shorelines at higher elevation on the southern margin of the Hanaupah Canyon fan complex (Hooke, 1972) are cut into older alluvium (unit Qao) and may be related to an MIS 6 highstand of at least 67 meters asl or to an older (MIS 8 or older) highstand that is poorly preserved and still undated in the valley.

\section{Former Lake Levels}

The longstanding paradigm for Lake Manly has been that the highstands were relatively deep (Hooke, 1972; Benson and others, 1990), but new studies suggest otherwise. See, for example, geomorphic studies by Knott and others (2002), mapping by Slate and others (in press), coring in the lake basin by Anderson (1998), Anderson and Wells (1996), and Lowenstein and others (1999), dating of the tufas at Badwater (BW, fig. 1) by Ku and others (1998), and a regional compilation of lake features (Machette, Klinger, Knott, and others, 2001). Knott and others (2002) concluded that most of the subparallel escarpments on Mormon Point are fault scarps, whereas Hooke (1972) interpreted them as multiple strandlines of Lake Manly. This restricts the maximum altitude for an MIS 2 lake to 30 meters below sea level (100 ft below sea level) or lower. Mapping provides further evidence of only shallow MIS 4 and MIS 2 lakes in Death Valley (Slate and others, in press). The Qai alluvium dated between $40 \mathrm{ka}$ and $100 \mathrm{ka}$ forms broad, smooth fan surfaces on the west side of 
the valley that extend down to at least 46 meters (150 ft) below sea level; aerial photography shows that they have not been transgressed by Lake Manly since at least $130 \mathrm{ka}$ as dated by depth profile 5. The largest potential water source for Lake Manly is Sierra Nevada waters flowing in the Owens River, through Panamint valleys and over Wingate Pass. Phillips and others' (2008) summary of dating of the Gale-stage (highest) shoreline features in Panamint Valley suggests that it was created during MIS 4, whereas Jayko and others (2001, 2008) and Stewart and others (2001) suggest that Panamint Lake has not overtopped Wingate Pass (fig. 1, WGP) since MIS 6. If the Gale-stage lake in Panamint Valley was short lived in MIS 4, or last overtopped its sill at Wingate Pass in MIS 6 , this would provide a logical explanation for only shallow phases of MIS 2 and MIS 4 lakes in Death Valley during the late Pleistocene (130-10 ka) (see Anderson and Wells, 2003). With only internal drainage from Death Valley watersheds and the Amargosa River, presently the largest stream flowing into Death Valley, the drainage system would seem incapable of producing a deep lake under full glacial conditions.

Thus, it appears that during the Quaternary, Death Valley was repeatedly occupied by a deep, climatically driven Lake Manly with inflow from the Sierra Nevada, culminating at about $130 \mathrm{ka}$ (MIS 6). Since that time, Sierra Nevada surface runoff must have terminated in Panamint Valley without affecting a spillover into Death Valley to the east. In contrast, subsequent late Pleistocene (130-10 ka) climatically driven paleolakes in Death Valley were likely relatively shallow and limited in lateral extent, as evidenced by a lack of shorelines on the Qai (100-40 ka) alluvial fans dated herein.

\section{Rates of Fault Slip and Uplift}

Knowing the absolute ages (or range in ages) of the intermediate-age (Qai) surfaces allows us to document deformation rates for a variety of active faults, such as lateral slip on the northern Death Valley fault zone, thrust faulting on the Echo Canyon fault in Furnace Creek Canyon, and uplift rates in the Mustard Canyon hills north of Furnace Creek.

\section{Offset Along the Northern Death Valley Fault Zone}

In northern Death Valley, a large alluvial fan shows spectacular evidence of right-lateral offset along the Northern Death Valley fault zone (Klinger, 2003). We refer to this fan as the Mile-22 fan (M22, fig. 1) for its location near the 1,000-ft elevation marker near NPS mileage marker 22 on Route 5 (Stop A3, Klinger and Sarna-Wojcicki, 2001). This fan is also referred to as the Red Wall Canyon fan (Frankel and others, 2007), although Red Wall Canyon is south of the source canyon for this site.

Mapping by Reynolds (1969) indicated 46 meters of right-lateral offset, but a palinspastic reconstruction of three prominent drainage channels shows 250-330 meters offset (Klinger and Sarna-Wojcicki, 2001, fig. A3-8). Using an estimated age range of 60-35 ka from soil development, Klinger and Sarna-Wojcicki (2001) suggested an average late Pleistocene lateral slip rate of $4-9 \mathrm{~mm} / \mathrm{yr}$ for this part of the fault zone, whereas offset radiocarbon-dated late Holocene deposits suggested a rate of 3-6 mm/yr. Both time slices and slip rates were rather broad, so further refinement of the longer term slip rate would help determine the regional slip budget across the eastern California shear zone in this portion of the southern Basin and Range province (see Frankel and others, 2007).

We sampled depth profiles from Klinger's (2003) Q2c surface (equivalent to a young phase of Qai) both west (S14) and east (S15) of the fault zone on the Mile 22 fan (also referred to as the Redwall Canyon fan by Frankel and others, 2007). Two ${ }^{36} \mathrm{Cl}$ depth-profile ages of $65 \mathrm{ka}$ and $55 \mathrm{ka}$ (table 5) were obtained from these sites, respectively, which confirms the lower end of the slip rates and higher end of ages estimated by Klinger (2003). Using our ${ }^{36} \mathrm{Cl}$ depth-profile ages, we calculate a minimum slip rate of $3.85 \mathrm{~mm} / \mathrm{yr}$ (250 m of offset in $65 \mathrm{kyr}$ ) and a maximum slip rate of $6 \mathrm{~mm} / \mathrm{yr}$ (330 $\mathrm{m}$ of offset in $55 \mathrm{kyr}$ ), with a preferred (median) value of about $5 \mathrm{~mm} / \mathrm{yr}$ (300 $\mathrm{m}$ of offset in $60 \mathrm{kyr}$ ). This site has been the subject of a comprehensive dating analysis using multiple cosmogenicnuclide methods and our ${ }^{36} \mathrm{Cl}$ depth-profile ages, which collectively yielded a similar estimate of slip rates for the Northern Death Valley fault zone (Frankel and others, 2007).

\section{Uplift of the Mustard Canyon Hills, North of Furnace Creek Ranch}

The northwest-southeast-trending Mustard Canyon hills $(\mathrm{MH}$, fig. 1) are a product of localized uplift in a transition zone between the southern end of the Northern Death Valley fault zone (dextral slip) and the northern end of the Black Mountains fault zone (oblique slip). Cored by ochre-colored mudstone of Pliocene age within the Furnace Creek Formation (formerly considered to be Miocene to Pliocene), the hills are capped by a thin mantle of Qai alluvium (fig. 13). Machette, Menges, Slate, and others (2001) described localized uplift and collapse of the gravel-covered hills adjacent to Mustard Canyon. Mapping of the deformed gravels suggests about 50 meters of post-Qai uplift relative to undeformed Qai alluvial fans to the east. A depth profile from site S17 yielded a ${ }^{36} \mathrm{Cl}$ depth-profile age of $79 \mathrm{ka}$ (fig. 12 and table 5), which is considerably younger than Machette, Menges, Slate, and others' (2001) geomorphic estimate of $200 \mathrm{ka}$ for the deformed gravels. The 79-ka age for the deformed Qai gravel results in a revised uplift rate of $0.63 \mathrm{~mm} / \mathrm{yr}(50 \mathrm{~m} / 79 \mathrm{kyr})$. The relatively fast uplift has resulted in extensive piping in the salt-bearing strata and, in some cases, nearly complete erosion and (or) collapse of the soft core of the dome-shaped hills (fig. 13). 


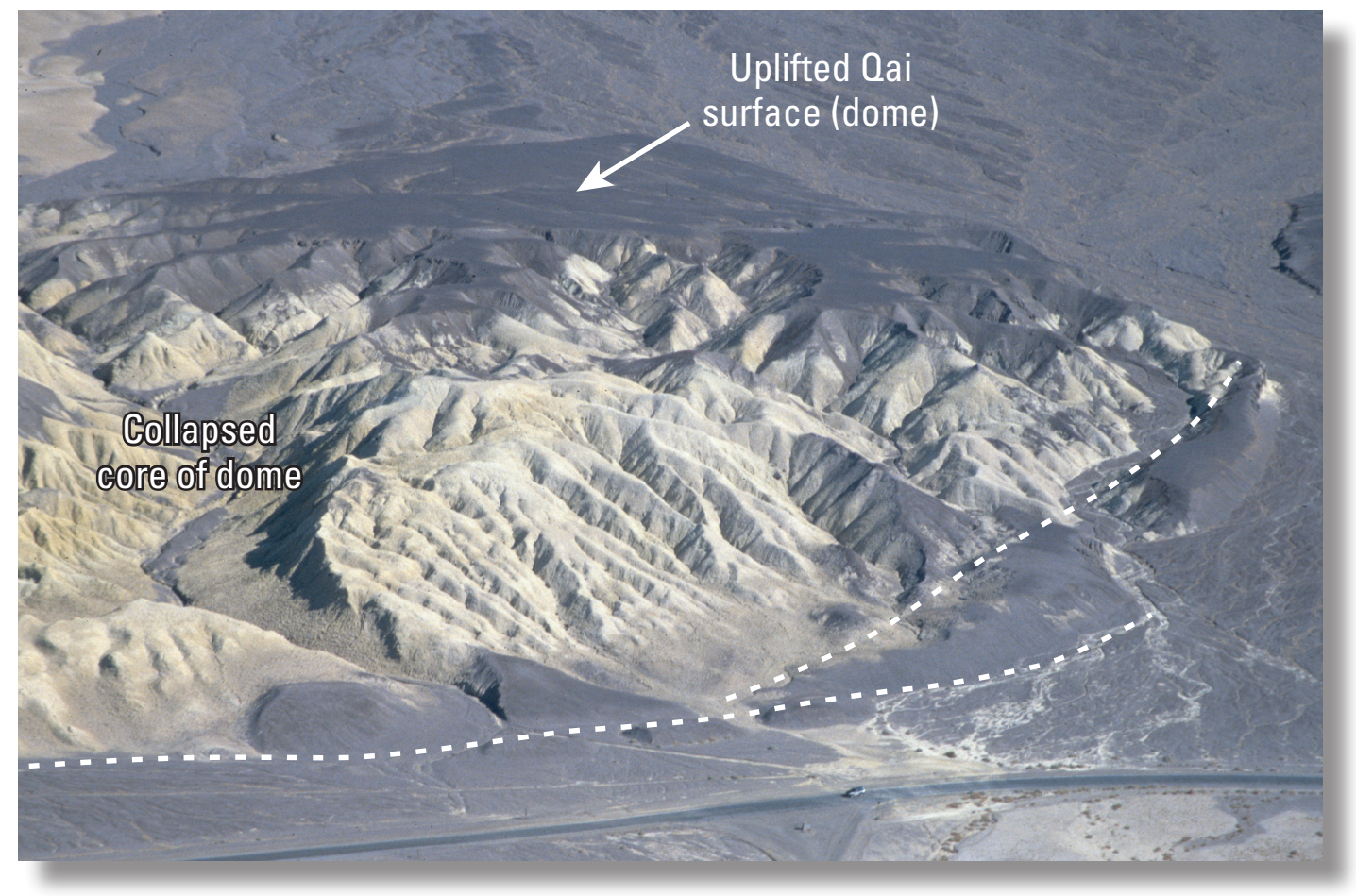

Figure 13. Eastward aerial view of the Mustard Canyon Hills, north of Furnace Creek. Hills are composed of Pliocene mudstones (Furnace Creek Formation) exposed in northwest-southeast-trending elongate domes with faulted margins (white dashed lines; see Machette, Menges, Slate, and others, 2001). Qai gravels have been uplifted and locally preserved on top of and around the margins of the hills. However, the cores of the hills commonly have collapsed as a result of dissolution of soluble salts in the Furnace Creek Formation.

\section{Thrusting Along the Echo Canyon Fault, Furnace Creek Canyon}

The Texas Springs syncline represents localized compression (folding and thrusting) between the largely Quaternary-dormant Funeral fault zone to the north and the Black Mountains block to the south (Machette, Menges, Slate, and others, 2001), which contains three Miocene to Quaternary detachment faults (see Knott and others, 2001). The south margin of the syncline is marked by a narrow, but active zone of thrusting, which Klinger and Piety (1996) mapped and named the Echo Canyon thrust (EC, fig. 1). Their Q2c alluvium (our unit Qai) has been repeatedly offset by thrusting that has formed numerous fresh-appearing scarps along a northwest-trending zone. Clear evidence of the fault (fig. 14) is seen in a stream cut that exposes an Av horizon on unit Q2c that has been overthrust by Qai alluvium and buried beneath the fault (see Stop B4.1, Klinger and Sarna-Wojcicki, 2001). Mapping by Klinger and Piety (1996) shows traces of the Echo Canyon fault extending along the north side of Furnace Creek for almost $10 \mathrm{~km}$.

We sampled site S16 in Qai alluvium near the southeast end of the Echo Canyon fault, using a natural exposure along the axis of a mild fold behind and northeast of the thrust.
Offset of this surface is variable along strike, ranging between 5 meters and 20 meters near Texas Springs. This is the vertical displacement component of a $30-45^{\circ}$ northeast-dipping fault, so the net dip-slip movement could be as much as twice the vertical component (that is, 10-40 meters). Depth profile S16 yielded an age of $97 \mathrm{ka}$ (table 5), which is the oldest age we obtained from samples of Qai alluvium. Movement along the Echo Canyon thrust early in the deposition interval of unit Qai probably uplifted and preserved material along the hanging wall of the thrust. Therefore, these sites should date older than if we sampled from a stable alluvial fan setting, such as on the west side of Death Valley. The ${ }^{36} \mathrm{Cl}$ depth-profile age of $97 \mathrm{ka}$ for the uplifted Qai surface yields a dip-slip rate of movement on the Echo Canyon thrust of $0.1-0.4 \mathrm{~mm} / \mathrm{yr}$. At these rates, 1 meter of dip-slip movement would be repeated every 2.5-10 kyr with complete strain release on the thrust fault.

\section{Summary}

Extensive ${ }^{36} \mathrm{Cl}$ depth-profile dating of the broad, relatively smooth and well-varnished alluvial fans in Death Valley (designated alluvial unit Qai by Slate and others, in press) suggests that these surfaces developed between $40 \mathrm{ka}$ and 




Figure 14. Natural exposure of the Echo Canyon fault showing southwest-vergent thrusting of Qai alluvium over itself. Fresh-appearing scarps, which are prominent on aerial photographs and in the field, suggest that the most recent movement is Holocene. Person in photograph (1.8 meters tall) for scale.

perhaps $100 \mathrm{ka}$ - over a long part of the late Pleistocene. Six of the 10 profiles from Qai alluvium date between $50 \mathrm{ka}$ and $90 \mathrm{ka}$ (fig. 12), which incompasses MIS 4. Some of the older dated Qai surfaces may have become geomorphically isolated from subsequent deposition by uplift or faulting as early as $100 \mathrm{ka}$ and some younger dated Qai surfaces may be a result of erosion. Surfaces underlain by alluvial unit Qai extend to elevations as low as 46 meters $(150 \mathrm{ft})$ below sea level yet show no evidence of having been transgressed by Lake Manly, suggesting that and late Pleistocene paleolakes in Death Valley were rather shallow during MIS 4 (75-60 ka) and MIS 2 (30-15 ka).

The remnant of a once-extensive lacustrine delta complex on the north margin of Hanaupah Canyon yielded a preferred ${ }^{36} \mathrm{Cl}$ depth-profile age of $130 \mathrm{ka}$, coincident with a highstand of Lake Manly at the close of MIS 6. Higher shorelines ( $\geq 67$ meters asl) cut on alluvium of unit Qao on the south margin of the Hanaupah Canyon fan may be related to either a deeper phase of Lake Manly during MIS 6 or an older (MIS $8+$ ) highstand that is poorly preserved and largely undated in the valley.

A major episode of alluvial-fan building occurred early during MIS 6, as evidenced by our $170-\mathrm{ka}{ }^{36} \mathrm{Cl}$ depth-profile age from Qaio, which is an older phase of alluvial unit Qai along Trail Canyon Road. Published surface-exposure dates on alluvial units older than Qai suggest numerous earlier fanbuilding episodes in the middle Pleistocene, but these deposits are highly eroded where they are preserved in Death Valley.

The ${ }^{36} \mathrm{Cl}$ depth-profile method of dating is particularly attractive in arid piedmont environments, where materials suitable for radiocarbon or luminescence dating may be sparse or nonexistent. Using the ${ }^{36} \mathrm{Cl}$ nuclide in pebble gravel, we have been able to date soils and their parent materials that span late-middle to late Pleistocene time (170-40 ka); however, the method may be suitable for even older materials (perhaps 200-300 kyr; see Gosse and Phillips, 2001) largely depending on the inherited component of ${ }^{36} \mathrm{C}$. Gravels of almost any lithology are acceptable hosts for cosmogenic chlorine, and sampling materials to depths of 2-3 m provide direct estimates of the probable inherited component of ${ }^{36} \mathrm{Cl}$. The component of inherited cosmogenic chlorine and other isotopes varies among deposits, source materials, and drainage areas, reflecting the degree to which clasts are eroded during transport, the lithologic-dependent resistance to clast erosion, and reworking of ${ }^{36} \mathrm{Cl}$-enriched, near-surface materials (upper 1 to $2 \mathrm{~m}$ of soil and parent material). In large boulders used for surface-exposure dating, this component may represent tens of thousands of years of exposure. This unknown component is included directly in boulder sampling, yielding highly variable ranges of ages that are accommodated by taking the mean age of large population of surface-exposure dates. In ${ }^{36} \mathrm{Cl}$ depthprofile dating of alluvium, the inherited ${ }^{36} \mathrm{Cl}$ is measured from deep samples of sand to boulder size clasts; if these clasts are incompletely freshened during transport or if the sediment has 
been locally reworked from the upper 1-2 m of older surficial materials (colluvium or alluvium), the inherited component may approach 100,000 years of equivalent exposure. Thus, the ${ }^{36} \mathrm{Cl}$ depth-profile methods described in this report probably are best restricted to alluvial materials deposited by energetic, bedrock-sourced streams or from alluvial surfaces that are no younger than the inherited component; for example, a 60-ka depositional age with $60 \mathrm{kyr}$ of inherited isotopes.

\section{Acknowledgments}

We appreciate the collaborative efforts of soil scientists Leon Lato and Doug Merkler (NCRS, Las Vegas, Nev.) and Quaternary geologists/pedologists Bruce Harrison (New Mexico Tech, Socorro, N. Mex.) and Brenda Buck (University of Nevada, Las Vegas), all of whom helped describe and sample the soils for our depth profiles. Bruce Harrison's Soils class at NMT performed the textural analyses presented in table A5, whereas Doug Merkler supplied soils data for calculating the composite bulk densities in table A6. Chris Menges helped locate and sample some of the profiles while working independently in Death Valley. Chlorine concentrates from gravel clasts were prepared by Terry Thomas (NMT, Socorro) for analysis by the PRIME Laboratory at Purdue University, Lafayette, Ind. The staff of the Death Valley National Park Natural Resources Department provided sampling permits and environmental clearance. We greatly benefited from field discussions of Quaternary geology, soils and geomorphology with Ralph Klinger (Bureau of Reclamation), Jeff Knott (California State University at Fullerton), Chris Menges (U.S. Geological Survey), and the hundreds of participants on our 2001 Friends of the Pleistocene field trip. The manuscript was technically reviewed for the U.S. Geological Survey by Chris Menges and Jeff Knott and edited by Tom Judkins and Mary Kidd of the U.S. Geological Survey.

\section{References Cited}

Anderson, D.E., 1998, Late Quaternary paleohydrology, lacustrine stratigraphy, fluvial geomorphology, and modern hydroclimatology of the Amargosa River Death Valley hydrologic system, California and Nevada: Riverside, University of California Riverside, unpublished Ph.D. dissertation, $521 \mathrm{p}$.

Anderson, D.E., and Wells, S.G., 1996, Latest Quaternary lacustrine events of Lake Manly-A record from ten shallow cores along a $70 \mathrm{~km}$ transect in southern Death Valley basin: Geological Society of America Abstracts with Programs, v. 28, no. 7, p. A458.
Anderson, D.E., and Wells, S.G., 2003, Latest Pleistocene lake highstands in Death Valley, California, in Enzel, Y., Wells, S.G., and Lancaster, N., eds., Paleoevents and paleohydrology of the Mojave and Southern Great Basin deserts: Geological Society of America Special Paper 368, p. 115-128.

Anderson, R.S., Repka, J.L., and Dick, G.S., 1996, Explicit treatment of inheritance in dating depositional surfaces using in situ ${ }^{10} \mathrm{Be}$ and ${ }^{26} \mathrm{Al}$ : Geology, v. 24, p. 47-51.

Beck, W., Donahue, D.J., Jull, A.J.T., Burr, G., Broecker, W.S., Bonani, G., Hajdas, I., Malotki, E., and Dorn, R.I., 1998, Ambiguities in direct dating of rock surfaces using radiocarbon measurements-Discussion and reply: Science, v. 280, no. 5372, p. 2132-2139.

Benson, L.V., Currey, D.R., Dorn, R.I., Lajoie, K.R., Oviatt, C.G., Robinson, S.W., Smith, G.I., and Stine, S., 1990, Chronology of expansion and contraction of four Great Basin lake systems during the past 35,000 years: Palaeoceanography, Palaeoclimatology, Palaeoecology, v. 78, p. $241-86$.

Bevington, P.R., and Robinson, D.K., 1992, Data reduction and error analysis for the physical sciences: New York, McGraw-Hill, 328 p.

Birkeland, P.W., 1999, Soils and geomorphology, 3d edition: New York, Oxford University Press, 430 p.

Birkeland, P.W., Machette, M.N., and Haller, K.M., 1991, Soils as a tool for applied Quaternary geology: Utah Geological and Mineral Survey Miscellaneous Publication, 63 p.

Blackwelder, E., 1933, Lake Manly-An extinct lake of Death Valley: Geographical Review, v. 23, p. 464-471.

Blackwelder, E., 1954, Pleistocene lakes and drainage in the Mojave region, southern California, [Chap. 5], in Jahns, R.H., ed., Geology of Southern California: California Division of Mines Bulletin 170, p. 35-40.

Burchfiel, B.C., and Stewart, J.H., 1966, 'Pull-apart' origin of the central segment of Death Valley, California: Geological Society of America Bulletin, v. 77, no. 4, p. 439-441.

Bull, W.B., 1991, Geomorphic responses to climatic change: New York, Oxford University Press, 326 p.

Davis, J.C., 2002, Statistics and data analysis in geology: New York, John Wiley \& Sons, 638 p.

Denny, C.S., 1965, Alluvial fans in the Death Valley region, California and Nevada: U.S. Geological Survey Professional Paper 466, 62 p., with 5 plates. 
Dohrenwend, J.C., 2001, Satellite image of Death Valley, Chapter D, in Machette, M.N., and others, eds., Quaternary and late Pliocene geology of the Death Valley regionRecent observations on tectonics, stratigraphy, and lake cycles (Guidebook for the 2001 Pacific Cell-Friends of the Pleistocene Fieldtrip): U.S. Geological Survey Open-File Report 2001-51, p. D117-D119.

Dohrenwend, J.C., Wells, S.G., and Turrin, B.D., 1986, Degradation of Quaternary cinder cones in the Cima volcanic field, Mojave Desert, California: Geological Society of America Bulletin, v. 97, p. 421-427.

Dokka, R.K., and Travis, C.J., 1990, The role of the Eastern California Shear Zone in accommodating Pacific-North American plate motion: Geophysical Research Letters, v. 17 , p. $1323-1326$.

Dorn, R.I., 1988, A rock varnish interpretation of alluvial-fan development in Death Valley, California: National Geographic Research, v. 4, p. 56-73.

Dühnforth, Miriam, Ivy-Ochs, Susan, Densmore, A.L., and Kubik, P.W., 2007, Constraints on the timing of fan deposition in Death Valley, California, using cosmogenic ${ }^{10} \mathrm{Be}$ and ${ }^{26} \mathrm{Al}$ : Geological Society of America Abstracts with Programs, v. 39, no. 6, p. 260.

Elmore, D., Fulton, B.R., Clover, M.R., Marsden, J.R., Gove, H.E., Naylor, H., Purser, K.H., Kilius, L.R., Beukens, R. P., and Litherland A.E., 1979, Analysis of ${ }^{36} \mathrm{Cl}$ in environmental samples using an electrostatic accelerator: Nature, v. 277, no. 5691, p. 22-25 (January 4, 1979).

Forester, R.M., Lowenstein, T.K., and Spencer, R.J., 2005, An ostracode based paleolimnologic and paleohydrologic history of Death Valley-200 to 0 ka: Geological Society of America Bulletin, v. 117, no. 11-12, p. 1379-1386 (DOI: 10.1130/B25637.1).

Frankel, K.L., Brantley, K.S., Dolan, J.F., Finkel, R.C., Klinger, R.E., Knott, J.R., Machette, M.N., Owen, L.A., Phillips, F.M., Slate, J.L., and Wernicke, B.P., 2007, Cosmogenic ${ }^{10} \mathrm{Be}$ and ${ }^{36} \mathrm{Cl}$ geochronology of offset alluvial fans along the northern Death Valley fault zone: Implications for transient strain in the eastern California shear zone: Journal of Geophysical Research, v. 112, B06407, doi:10:1029/2006JB004350.

Gillespie, A., 1988, Letter to the editor in response to article by Dorn et al.: Quaternary Research, v. 30, no. 1, p. 102-103.

Gosse, J.C., McDonald, E.V., and Finkel, R., 2003, Cosmogenic nuclide dating of arid region alluvial fans: Geological Society of America Abstracts with Programs, v. 35, no. 3, p. 228.
Gosse, J.C., McDonald, E.V., Pederson, J., Stockli, D.F., Lee, J., Stockli, L.D., and Yang, G., 2004, Oxygen isotope stage 4 sediment dominates the U.S. Southwest alluvial record: Geological Society of America Abstracts with Programs, v. 36 , no. 5 , p. 307.

Gosse, J.C., and Phillips, F.M., 2001, Terrestrial in situ cosmogenic nuclides-Theory and application: Quaternary Science Reviews, v. 20, no. 14, p. 1475-1560.

Harden, J.W., and Taylor, E.M., 1983, A quantitative comparison of soil development in four climatic regimes: Quaternary Research, v. 20, no. 3, p. 342-360.

Hooke, R. LeB., 1965, Alluvial fans: Pasadena, California Institute of Technology, unpublished Ph.D. dissertation, $192 \mathrm{p}$.

Hooke, R. LeB., 1972, Geomorphic evidence for late-Wisconsin and Holocene tectonic deformation, Death Valley, California: Geological Society of America Bulletin, v. 83, p. 2073-2098.

Hooke, R. LeB., and Dorn, R.I., 1992, Segmentation of alluvial fans in Death Valley, California-New insights from surface-exposure dating and laboratory modeling: Earth Surface Processes and Landforms, v. 17, no. 6, p. 57-574.

Hunt, C.B., and Mabey, D.R., 1966, Stratigraphy and structure of Death Valley, California: U.S. Geological Survey Professional Paper 494-A, 162 p., 3 plates (plate 1, 1:96,000 scale).

Ibbeken, H., Warnke, D.A., and Diepenbroek, M., 1998, Granulometric study of the Hanaupah fan, Death Valley, California: Earth Surface Processes and Landforms, v. 23, p. 481-492.

Ibbeken, H., and Warnke, D.A., 2000, The Hanaupah-fan shoreline deposit at Tule Spring-A gravelly shoreline deposit of Pleistocene Lake Manly, Death Valley, California, USA: Journal of Paleolimnology, v. 23, no. 4, p. 439-447.

Jayko, A.S., Forester, R.M., Sharpe, S., and Smith, G.L., 2001, The last pluvial highstand (late Wisconsin, Tioga age) in Panamint Valley, southeast California: Eos (Transactions of the American Geophysical Union), Fall Meeting Supplement, v. 82, no. 47, Abstract PP42B-0530.

Jayko, A.S., Forester, R.M., Kaufman, D.S., Yount, J.C., McGeehin, J., and Mahan, S.A., 2008, Late Pleistocene lake and wetlands, Panamint Valley, Inyo County, California, in Reheis, M.C., Hershler, R., and Miller, D.M., eds., Late Cenozoic drainage history of the southwestern Great Basin and Lower Colorado River region-Geologic and biotic perspectives: Geological Society of America Special Paper 439, p. 151-184, doi: 10.1130/2008.2439(06). 
Klinger, R.E., 2003, Quaternary stratigraphy, soil geomorphology, and tephrochronology of northern Death ValleyImplications for tectonic activity along the northern Death Valley fault: Boulder, University of Colorado, Ph.D. dissertation, $312 \mathrm{p}$.

Klinger, R.E., and Piety, L.A., 1996, Evaluation and characterization of Quaternary faulting on the Death Valley and Furnace Creek faults, Death Valley, California: Bureau of Reclamation, Technical Service Center, Denver, Colorado, Yucca Mountain Project Activity 8.3.1.17.4.3.2, Seismotectonics Report 96-10, Seismotectonics and Geophysics Section, $98 \mathrm{p}$.

Klinger, R.E., and Sarna-Wojcicki, A.M., 2001, Field trip guide for Day A, northern Death Valley, in Machette, M.N., and others, eds., Quaternary and late Pliocene geology of the Death Valley region-Recent observations on tectonics, stratigraphy, and lake cycles (Guidebook for the 2001 Pacific Cell-Friends of the Pleistocene Fieldtrip): U.S. Geological Survey Open-File Report 2001-51, p. A5-A49.

Knott, J.R., Jayko, A.S., and Sarna-Wojcicki, A.M., 2000, Late Pliocene alluvial fan deposits, eastern Panamint Mountains piedmont, Death Valley, California: Geological Society of American Abstracts with Programs, v. 32, no. 7, p. 183.

Knott, J.R., Sarna-Wojcicki, A.M., Tinsley, J.C., Wells, S.G., and Machette, M.N., 2001, Field trip guide for Day C, Central Death Valley, in Machette, M.N., and others, eds., Quaternary and late Pliocene geology of the Death Valley region-Recent observations on tectonics, stratigraphy, and lake cycles (Guidebook for the 2001 Pacific Cell-Friends of the Pleistocene Fieldtrip): U.S. Geological Survey OpenFile Report 2001-51, C89-C116.

Knott, J.R., Tinsley, J.C., and Wells, S.G., 2002, Are the benches at Mormon Point, Death Valley, California, USA, scarps or strandlines?: Quaternary Research, v. 58, p. 362-360.

Ku, T.L., Luo, S., Lowenstein, T.K., Li, J., and Spencer, R.J., 1998, U-Series chronology of lacustrine deposits in Death Valley, California: Quaternary Research, v. 50, p. 261-275.

Kurth, G.E., 2003, Cosmogenic nuclide dating of old, high pluvial shorelines in the western Great Basin: Socorro, New Mexico Institute of Mining and Technology, Master's thesis, $158 \mathrm{p}$.

Lal, D., 1991, Cosmic-ray labeling of erosion surfaces-In situ production rates and erosion models: Earth and Planetary Science Letters, v. 104, p. 424-439.

Lowenstein, T.K., Li, J., Brown, C., Roberts, S.M., Ku, T.-L., Luo, S., and Yang, W., 1999, 200 k.y. paleoclimate record from Death Valley salt core: Geology, v. 27, no. 1, p. 3-6.
Machette, M.N., 1985, Calcic soils of the southwestern United States, in Weide, D.L., ed., Soils and Quaternary geology of the southwestern United States: Geological Society of America Special Paper 203, p. 1-21.

Machette, M.N., Johnson, M.L., and Slate, J.L., eds., 2001, Quaternary and Late Pliocene geology of the Death Valley region-Recent observations on tectonics, stratigraphy, and lake cycles (Guidebook for the 2001 Pacific Cell-Friends of the Pleistocene Fieldtrip): U.S. Geological Survey OpenFile Report 2001-51, 246 p.

Machette, M.N., Klinger, R.E., and Knott, J.R., 2001, Questions about Lake Manly's age, extent, and source, in Machette, M.N., and others, eds., Quaternary and late Pliocene geology of the Death Valley region-Recent observations on tectonics, stratigraphy, and lake cycles (Guidebook for the 2001 Pacific Cell—Friends of the Pleistocene Fieldtrip): U.S. Geological Survey Open-File Report 2001-51, p. 143-149.

Machette, M.N., Klinger, R.E., Knott, J.R., Wills, C.J., Bryant, W.A., and Reheis, M.C., 2001, A proposed nomenclature for the Death Valley fault system, in Machette, M.N., and others, eds., Quaternary and late Pliocene geology of the Death Valley region-Recent observations on tectonics, stratigraphy, and lake cycles (Guidebook for the 2001 Pacific Cell-Friends of the Pleistocene Fieldtrip): U.S. Geological Survey Open-File Report 2001-51, p. 173-183.

Machette, M.N., Menges, C.M., Slate, J.L., Crone, A.J., Klinger, R.E., Piety, L.A., Sarna-Wojcicki, A.M., and Thompson, R.A., 2001, Chapter B-Field trip guide for Day B, Furnace Creek area, in Machette, M.N., and others, eds., Quaternary and late Pliocene geology of the Death Valley region-Recent observations on tectonics, stratigraphy, and lake cycles (Guidebook for the 2001 Pacific Cell-Friends of the Pleistocene Fieldtrip): U.S. Geological Survey Open-File Report 2001-51, p. B51-B52.

Machette, M.N., Ninci Martinez, Carlos, Crone, A.J., Haller, K.M., and D'Addezio, Giuliana, 1999, Geologic and seismic hazard investigations of the Cow Creek area, Death Valley National Park, California: U.S. Geological Survey Open-File Report 99-155, 42 p.

Mann, Paul, Hempton, M.R., Bradley, D.C., and Burke, Kevin, 1983, Development of pull-apart basins: Journal of Geology, v. 91, no. 5, p. 529-554.

McFadden, L.D., McDonald, E.V., Wells, S.G., Anderson, K., Quade, J., and Forman, S.L., 1998, The vesicular layer and carbonate collars of desert soils and pavements-Formation, age, and relation to climate change: Geomorphology, v. 24, no. 2-3, p. 101-145. 
Menges, C.M., Taylor, E.M., Workman, J.B., and Jayko, A.S., 2001, Chapter H-Regional surficial-deposit mapping in the Death Valley area of California and Nevada in support of ground-water modeling, in Machette, M.N., and others, eds., Quaternary and Late Pliocene geology of the Death Valley region-Recent observations on tectonics, stratigraphy, and lake cycles (Guidebook for the 2001 Pacific Cell-Friends of the Pleistocene Fieldtrip): U.S. Geological Survey Open-File Report 2001-51, p. H151-H166.

Nishiizumi, K., Kohl, C.P., Arnold, J.R., Dorn, R., Klein, J., Fink, D., Middleton, R., and Lal, D., 1993, Role of in situ cosmogenic nuclides ${ }^{10} \mathrm{Be}$ and ${ }^{26} \mathrm{Al}$ in the study of diverse geomorphic processes: Earth Surface Processes and Landforms, v. 18, no. 5, p. 407-425.

Phillips, F.M., 2008, Geological and hydrological history of the paleo-Owens River drainage since the late Miocene, in Reheis, M.C., Hershler, R., and Miller, D.M., eds., Late Cenozoic drainage history of the southwestern Great Basin and Lower Colorado River region: Geologic and biotic perspectives: Geological Society of America Special Paper 439, p. 115-150, doi: 10.1130/2008.2439(06).

Phillips, F.M., Ayarbe, J.P., Harrison, B.J., and Elmore D., 2003, Dating rupture events on alluvial fault scarps using cosmogenic nuclides and scarp morphology: Earth and Planetary Science Letters, v. 215, p. 203-218.

Phillips, F.M., Leavy, B.D., Jannik, N.D., Elmore, D., Kubik, P.W., Dorn, R.I., and Roddy, D.J., 1986, The accumulation of cosmogenic chlorine-36 in rocks-A method for surface exposure dating: Science, v. 231, p. 41-43.

Phillips, F.M., and Plummer, M.A., 1996, CHLOE-A program for interpreting in-situ cosmogenic nuclide data for surface exposure dating and erosion studies: Radiocarbon, v. 38, no. 1, p. 98-99, Abstracts of 7th International Conference on Accelerator Mass Spectrometrometry, Tucson, Arizona.

Phillips, F.M., Stone, W.D., and Fabryka-Martin, J.T., 2001, An improved approach to calculating low-energy cosmicray neutron fluxes near the land/atmosphere interface: Chemical Geology, v. 175, no. 3-4, p. 689-701.

Reheis, M.C., Slate, J.L., Throckmorton, C.K., McGeehin, J.P., Sarna-Wojcicki, A.M., and Dengler, L., 1996, Late Quaternary sedimentation of the Leidy Creek fan, NevadaCalifornia-Geomorphic responses to climate change: Basin Research, v. 12, p. 279-299.

Repka, J.L., Anderson, R.S., and Finkel, R.C., 1997, Cosmogenic dating of fluvial terraces, Fremont River, Utah: Earth and Planetary Science Letters, v. 152, p. 59-73.
Reynolds, M.W., 1969, Stratigraphy and structural geology of the Titus Canyon and Titanothere Canyons area, Death Valley, California: Berkeley, University of CaliforniaBerkeley, unpublished Ph.D. dissertation, 310 p.

Singer, M.J., and Janitzky, P., editors, 1986, Field and laboratory procedures used in a soil chronosequence study: U.S. Geological Survey Bulletin 1648, 49 p.

Slate, J.L., Berry, M.E., and Menges, C.M., in press, Surficial geologic map of the Death Valley Junction $30^{\prime} \times 60^{\prime}$ quadrangle, California and Nevada: U.S. Geological Survey Scientific Investigations Map 3013, 1 sheet, 1:100,000 scale.

Soil Survey Staff, 1993, Soil survey manual: U.S. Department of Agriculture Handbook no. 18, 437 p.

Soil Survey Staff, 1999, Soil taxonomy: U.S. Department of Agriculture, Agriculture Handbook no. 436, 754 p.

Stewart, B.W., Roof, S., Boulanger, J.R., and Lowenstein, T.K., 2001, Connectivity of Owens River system paleolakes during Quaternary glacial periods-The strontium isotope record: Eos (Transactions of the American Geophysical Union), Fall Meeting Supplement, v. 82, no. 47, Abstract PP22A-0493.

Stiles, C.A., Mora, C.I., Driese, S.G., and Robinson, A.C., 2003, Distinguishing climate and time in the soil record: Mass-balance trends in vertisols from the Texas coastal prairie: Geology, v. 31, p. 331-334.

Stone, J., Evans, J., Fifield, K., Cresswell, R., and Allan, G., 1996a, Cosmogenic chlorine-36 production rates from calcium and potassium: Radiocarbon, v. 38, no. 1, p. 170-171.

Stone, J.O., Allan, G.L., Fifield, L.K., and Cresswell, R.G., 1996b, Cosmogenic chlorine-36 from calcium spallation: Geochimica et Cosmochimica Acta, v. 60, no. 4, p. 679-692.

Stone, J.O.H., Evans, J.M., Fifield, L.K., Allan, G.L., and Cresswell, R.G., 1998, Cosmogenic chlorine-36 production in calcite by muons: Geochimica et Cosmochimica Acta, v. 62 , p. $433-454$.

Watchman, Alan, 2000, A review of the history of dating rock varnishes: Earth Science Reviews, v. 49, no. 1-4, p. 261-277.

Whipple K.X., and Trayler, C.R., 1996, Tectonic control of fan size-The importance of spatially variable subsidence rates: Basin Research, v. 8, p. 851-366. 
Workman, J.B., Menges, C.M., Page, W.R., Taylor, E.M., Ekren, E.B., Rowley, P.D., Dixon, G.L., Thompson, R.A., and Wright, L.A, 2002, Geologic map of the Death Valley ground-water model area, Nevada and California: U.S. Geological Survey Miscellaneous Field Studies Map 2381-A, 2 sheets 1:250,000 scale.

Zreda, M.G., 1994, Development and calibration of the cosmogenic ${ }^{36} \mathrm{Cl}$ surface exposure dating method and its application to the chronology of late Quaternary glaciations: Socorro, New Mexico Institute of Mining and Technology, $\mathrm{Ph} . \mathrm{D}$. dissertation, $258 \mathrm{p}$.

Zreda, M.G., and Phillips, F.M., 1994, Surface exposure dating by cosmogenic chlorine-36 accumulation, in Beck, Charlotte, ed., Dating in exposed and surface contexts: Albuquerque, University of New Mexico Press, p. 161-183. 
Appendixes 
Table A1. Locations of depth-profile sampling sites in Death Valley, California.

[UTM, Universal Transverse Mercator; NAD 27, North American Datum; m, meters; km, kilometers; Cyn, Cyn; Springs, Spgs; NDVFZ, Northern Death Valley fault zone; Hwy, highway]

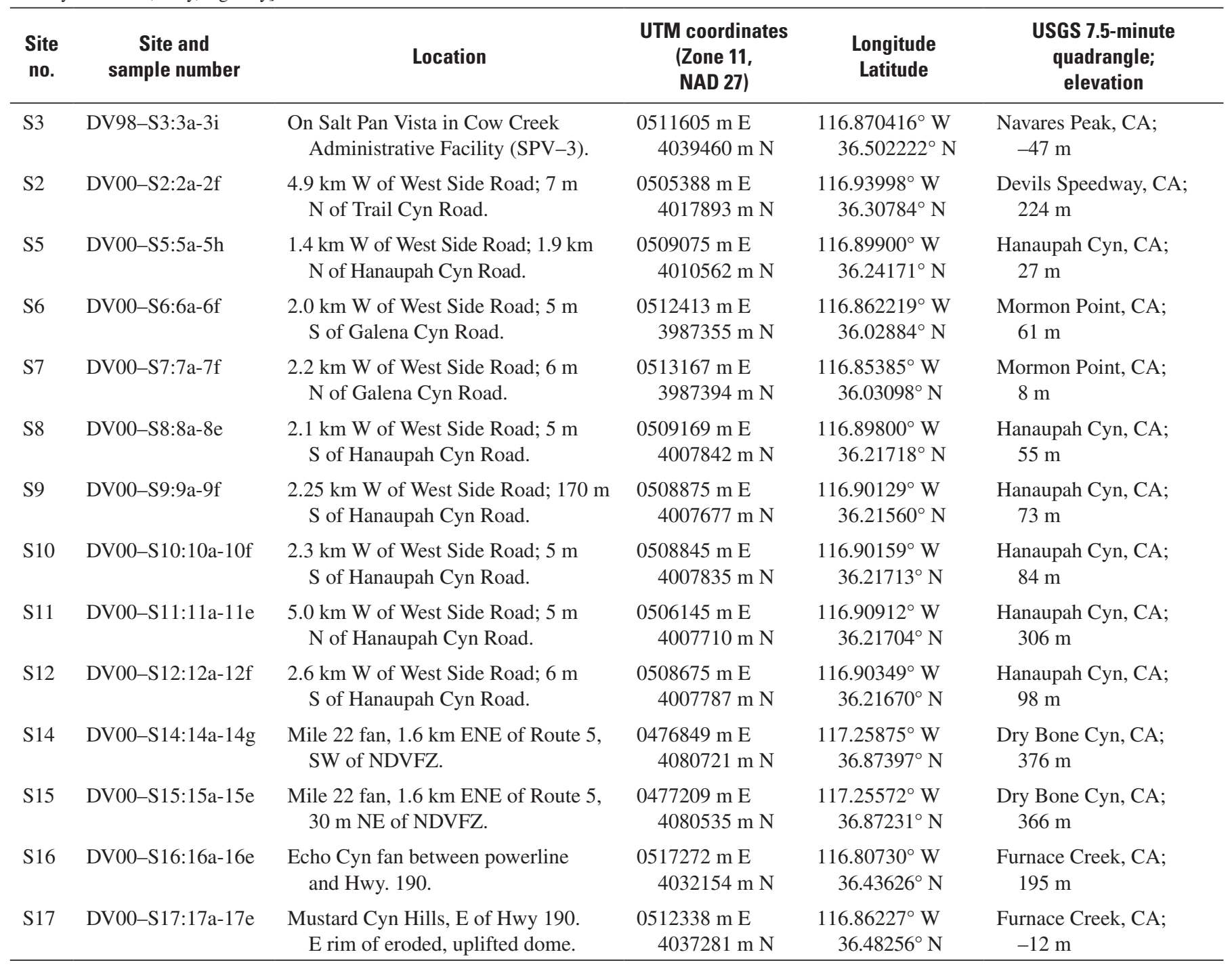


Table A2. Locations of sediment- and rock-sampling sites in Death Valley, California.

[UTM, Universal Transverse Mercator; NAD, North American datum; m, meters; ca., circa (about)]

\begin{tabular}{|c|c|c|c|c|c|}
\hline $\begin{array}{l}\text { Site } \\
\text { no. }\end{array}$ & $\begin{array}{l}\text { Sample } \\
\text { no. }\end{array}$ & Sampled material and location & $\begin{array}{l}\text { UTM (Zone 11, } \\
\text { NAD 27) }\end{array}$ & $\begin{array}{l}\text { Latitude, } \\
\text { Longitude }\end{array}$ & $\begin{array}{l}\text { USGS 7.5-minute quad- } \\
\text { rangle; elevation }\end{array}$ \\
\hline $1 \mathrm{TC}$ & DV00-1TC & $\begin{array}{l}\text { Proximal alluvium; } 7.2 \mathrm{~km} \mathrm{~W} \text { of West Side } \\
\text { Road; } 100 \mathrm{~m} \mathrm{~S} \text { of Trail Canyon Road. }\end{array}$ & $\begin{array}{l}0502726 \mathrm{~m} \mathrm{E} \\
4018105 \mathrm{~m} \mathrm{~N}\end{array}$ & $\begin{array}{l}36.30920^{\circ} \mathrm{N} \\
116.96927^{\circ} \mathrm{W}\end{array}$ & $\begin{array}{l}\text { Devils Speedway, CA; } \\
\quad 425 \mathrm{~m}\end{array}$ \\
\hline $2 \mathrm{TC}$ & DV00-2TC & $\begin{array}{l}\text { Metamorphic quartzite boulder ( } 0.8 \mathrm{~m} \text { x } 1.2 \mathrm{~m} \\
\text { x } 1.6 \mathrm{~m}) ; 5.5 \mathrm{~km} \text { W of West Side Road; } 470 \\
\text { m N of Trail Canyon Road. Boulder may be } \\
\text { exhumed }(1-2 \mathrm{~m}) \text {. }\end{array}$ & $\begin{array}{l}0504812 \mathrm{~m} \mathrm{E} \\
4018360 \mathrm{~m} \mathrm{~N}\end{array}$ & $\begin{array}{l}36.31205^{\circ} \mathrm{N} \\
116.94640^{\circ} \mathrm{W}\end{array}$ & $\begin{array}{l}\text { Devils Speedway, CA; } \\
270 \mathrm{~m}\end{array}$ \\
\hline $3 \mathrm{TC}$ & DV00-3TC & $\begin{array}{l}\text { Metamorphic quartzite boulder (1.5 m x } 1.6 \\
\mathrm{~m} \text { x } 1.3 \mathrm{~m}) ; 5.6 \mathrm{~km} \text { W of West Side Road; } \\
10 \mathrm{~m} \mathrm{~S} \text { of Trail Canyon Road. }\end{array}$ & $\begin{array}{l}0504388 \mathrm{~m} \mathrm{E} \\
4018012 \mathrm{~m} \mathrm{~N}\end{array}$ & $\begin{array}{l}36.30892^{\circ} \mathrm{N} \\
116.95167^{\circ} \mathrm{W}\end{array}$ & $\begin{array}{l}\text { Devils Speedway, CA; } \\
\quad 308 \mathrm{~m}\end{array}$ \\
\hline $4 \mathrm{HC}$ & DV00-4HC & $\begin{array}{l}\text { Granitic boulder ( } 1.3 \mathrm{~m} \text { x } 1.2 \mathrm{~m} \text { x } 2.2 \mathrm{~m}) \text {; ca. } \\
200 \mathrm{~m} \text { N of Hanaupah Canyon Road; } 4.7 \\
\text { km WSW of West Side Road. }\end{array}$ & $\begin{array}{l}0506099 \mathrm{~m} \mathrm{E} \\
4007912 \mathrm{~m} \mathrm{~N}\end{array}$ & $\begin{array}{l}36.21777^{\circ} \mathrm{N} \\
116.93210^{\circ} \mathrm{W}\end{array}$ & $\begin{array}{l}\text { Hanaupah Cyn, CA; } \\
\quad 308 \mathrm{~m}\end{array}$ \\
\hline $18 \mathrm{HF}$ & DV00-18HF & $\begin{array}{l}\text { Proximal alluvium of Hanaupah Canyon; } 50 \\
\text { m SW of Hanaupah Canyon Road where it } \\
\text { enters canyon. }\end{array}$ & $\begin{array}{l}0503589 \mathrm{~m} \mathrm{E} \\
4007090 \mathrm{~m} \mathrm{~N}\end{array}$ & $\begin{array}{l}36.21044^{\circ} \mathrm{N} \\
116.96007^{\circ} \mathrm{W}\end{array}$ & $\begin{array}{l}\text { Hanaupah Cyn, CA; } \\
\quad 494 \text { m }\end{array}$ \\
\hline $19 \mathrm{HC}$ & DV00-19HC & $\begin{array}{l}\text { Distal alluvium of Hanaupah Canyon; ca. } 2.1 \\
\text { km WSW of West Side Road; } 360 \text { m S of } \\
\text { Hanaupah Canyon Road. }\end{array}$ & $\begin{array}{l}0509019 \mathrm{~m} \mathrm{E} \\
4007498 \mathrm{~m} \mathrm{~N}\end{array}$ & $\begin{array}{l}36.21409^{\circ} \mathrm{N} \\
116.89966^{\circ} \mathrm{W}\end{array}$ & $\begin{array}{l}\text { Hanaupah Cyn, CA; } \\
\quad 61 \mathrm{~m}\end{array}$ \\
\hline 20TC & DV00-20TC & $\begin{array}{l}\text { Distal alluvium of Trail Canyon; ca. } 130 \mathrm{~m} \\
\text { west of West Side Road opposite sharp } \\
\text { N-NE bend in road. }\end{array}$ & $\begin{array}{l}0509931 \mathrm{~m} \mathrm{E} \\
\quad 4019395 \mathrm{~m} \mathrm{~N}\end{array}$ & $\begin{array}{l}36.32134^{\circ} \mathrm{N} \\
116.88936^{\circ} \mathrm{W}\end{array}$ & $\begin{array}{l}\text { Devils Speedway, CA; } \\
\quad-73 \mathrm{~m}\end{array}$ \\
\hline
\end{tabular}


Table A3. Sample information for ${ }^{36}$ chlorine depth-profile dating.

[Soil horizons designations from Soil Survey Staff, 1993. Abbreviations: NMT, New Mexico Institute of Technology; NRCS, Natural Resources Conservation Service (formerly SCS); NS, not sampled; NA, not analyzed; dup., duplicate analysis]

\begin{tabular}{|c|c|c|c|c|c|c|c|c|}
\hline \multirow[b]{2}{*}{$\begin{array}{l}\text { Site } \\
\text { no. }\end{array}$} & \multirow[b]{2}{*}{$\begin{array}{l}\text { Sample no., } \\
\text { site name }\end{array}$} & \multicolumn{2}{|c|}{ Soil description } & \multicolumn{2}{|c|}{ Soil Analyses (NMT) } & \multicolumn{3}{|c|}{ TCN depth profile (PRIME Lab.) } \\
\hline & & $\begin{array}{l}\text { Depth } \\
\text { (cm) }\end{array}$ & Horizon & Depth & Laboratory & $\begin{array}{l}\text { Depth } \\
\text { (cm) }\end{array}$ & $\begin{array}{c}\text { Sample } \\
\text { no. }\end{array}$ & $\begin{array}{l}\text { Laboratory } \\
\text { no. }\end{array}$ \\
\hline S3 & $\begin{array}{l}\text { DV98-S3 } \\
\text { Cow Creek } \\
\text { Admin. } \\
\text { (SPV-3) }\end{array}$ & $\begin{array}{l}\text { Weak (Holoce } \\
\text { sampled: } \\
0-7 \\
7-35 \\
35-50\end{array}$ & $\begin{array}{l}\text { e) soil, not } \\
\text { Av } \\
\text { By } \\
\text { Bky }\end{array}$ & $\begin{array}{r}\text { Not sampled } \\
\text { textural an }\end{array}$ & & $\begin{array}{l}\text { SPV-3: } \\
0-10 \\
15-25 \\
35-45 \\
90-100 \\
185-195\end{array}$ & $\begin{array}{l}3 \mathrm{a}: \\
3 \mathrm{~b}: \\
3 \mathrm{c}: \\
3 \mathrm{e}: \\
3 \mathrm{i}:\end{array}$ & $\begin{array}{l}\text { T01-1009 } \\
\text { T01-1010 } \\
\text { T01-1011 } \\
\text { T01-1012 } \\
\text { T01-1013 }\end{array}$ \\
\hline $\mathrm{S} 2$ & $\begin{array}{l}\text { DV00-S2 } \\
\text { Trail Canyon }\end{array}$ & $\begin{array}{l}010221 \mathrm{DM}-1 \\
0-6 \\
6-16 \\
16-74 \\
74-125 \\
125-170+\end{array}$ & $\begin{array}{c}\text { (NRCS): } \\
\text { A1 } \\
\text { A2 } \\
\text { Bky } \\
\text { Bky } \\
\text { Bky }\end{array}$ & $\begin{array}{l}\text { DV1 soil pr } \\
\quad 0-15 \\
15-30 \\
30-50 \\
50-80 \\
80-110 \\
110-140 \\
140-170\end{array}$ & $\begin{array}{l}\text { DV1-1 (Av) } \\
\text { DV1-2 } \\
\text { DV1-3 } \\
\text { DV1-4 } \\
\text { DV1-5 } \\
\text { DV1-6 } \\
\text { DV1-7 }\end{array}$ & $\begin{array}{l}\text { DV00-S2: } \\
\text { 10-16 } \\
30-38 \\
60-68 \\
90-110 \\
132-145 \\
175-185\end{array}$ & $\begin{array}{l}\text { S2a: } \\
\text { S2b: } \\
\text { S2c: } \\
\text { S2d: } \\
\text { S2e: } \\
\text { S2f: }\end{array}$ & $\begin{array}{l}\text { T01-1009 } \\
\text { T01-1010 } \\
\text { T01-1011 } \\
\text { T01-1012 } \\
\text { T01-1013 } \\
\text { T01-1014 }\end{array}$ \\
\hline S5 & $\begin{array}{l}\text { DV00-S5 } \\
\text { Hanaupah } \\
\text { bar complex }\end{array}$ & $\begin{array}{l}030208 \mathrm{DM}-1 \\
2-0 \\
0-7 \\
7-22 \\
22-44 \\
44-100 \\
100+\end{array}$ & $\begin{array}{l}\text { (NRCS): } \\
\text { dp } \\
\text { A } \\
\text { Bk1 } \\
\text { Bk2 } \\
\text { Bk3 } \\
\text { C }\end{array}$ & 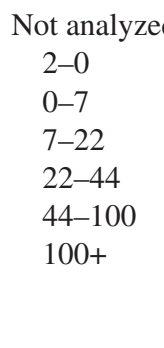 & $\begin{array}{l}\text { NS } \\
\text { S5-1 } \\
\text { S5-2 } \\
\text { S5-3 } \\
\text { S5-4 } \\
\text { NS }\end{array}$ & $\begin{array}{l}\text { DV00-S5: } \\
\text { 5-15 } \\
45-55 \\
65-75 \\
100-110 \\
150-160 \\
200-210 \\
400 \pm \\
700 \pm\end{array}$ & $\begin{array}{l}\text { S5f: } \\
\text { S5e: } \\
\text { S5d: } \\
\text { S5c: } \\
\text { S5b: } \\
\text { S5a: } \\
\text { S5g: } \\
\text { S5h: }\end{array}$ & $\begin{array}{l}\text { T01-0947 } \\
\text { T01-0946 } \\
\text { NA } \\
\text { T01-0945 } \\
\text { NA } \\
\text { T01-0944 } \\
\text { T01-0948 } \\
\text { NA }\end{array}$ \\
\hline S6 & $\begin{array}{l}\text { DV00-S6 } \\
\text { Galena Canyon }\end{array}$ & $\begin{array}{l}010222 \text { LL-2 } \\
\quad 0-3 \\
3-15 \\
15-40 \\
40-168+\end{array}$ & $\begin{array}{l}\text { NRCS): } \\
\text { Aky } \\
\text { Btkyz } \\
\text { Bkyz1 } \\
\text { Bkyz2 }\end{array}$ & $\begin{array}{l}\text { DV2 soil pro } \\
\quad 0-1 \\
1-5 \\
5-15 \\
15-30 \\
30-50 \\
50-70 \\
70-90 \\
90-110 \\
110-140 \\
140-160\end{array}$ & $\begin{array}{l}\text { DV2-1 } \\
\text { DV2-2 } \\
\text { DV2-3 } \\
\text { DV2-4 } \\
\text { DV2-5 } \\
\text { DV2-6 } \\
\text { DV2-7 } \\
\text { DV2-8 } \\
\text { DV2-9 } \\
\text { DV2-10 }\end{array}$ & $\begin{array}{c}\text { DV00-S6: } \\
\text { 13-21 } \\
41-53 \\
72-84\end{array}$ & $\begin{array}{l}\text { S6a: } \\
\text { S6b: } \\
\text { S6c: } \\
\text { S6c: } \\
\text { S6d: } \\
\text { S6e: } \\
\text { S6f: }\end{array}$ & $\begin{array}{l}\text { T02-0827 } \\
\text { T02-0828 } \\
\text { T02-0829 } \\
\text { R02-1457(dup) } \\
\text { T02-0830 } \\
\text { T02-0831 } \\
\text { NA }\end{array}$ \\
\hline S7 & $\begin{array}{l}\text { DV00-S7 } \\
\text { Galena Canyon }\end{array}$ & 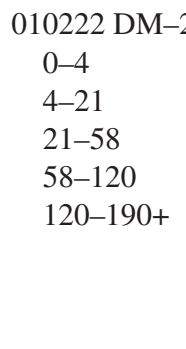 & $\begin{array}{l}\text { (NRCS): } \\
\text { A } \\
\text { Btky } \\
\text { Bkyq } \\
\text { Bky } \\
\text { Bk }\end{array}$ & $\begin{array}{l}\text { DV3 soil prc } \\
\quad 0-1 \\
1-8 \\
8-21 \\
21-58 \\
58-90 \\
90-120 \\
120-150 \\
150-170\end{array}$ & $\begin{array}{l}\text { DV3-1 } \\
\text { DV3-2 } \\
\text { DV3-3 } \\
\text { DV3-4 } \\
\text { DV3-5 } \\
\text { DV3-6 } \\
\text { DV3-7 } \\
\text { DV3-8 }\end{array}$ & 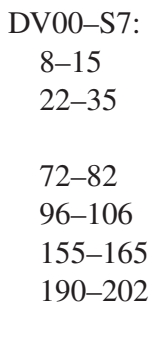 & $\begin{array}{l}\text { S7a: } \\
\text { S7b: } \\
\text { S7c: } \\
\text { S7d: } \\
\text { S7e: } \\
\text { S7f: }\end{array}$ & $\begin{array}{l}\text { T01-1015 } \\
\text { T01-1016 } \\
\text { T01-1017 (dup) } \\
\text { T01-1018 } \\
\text { T01-1019 } \\
\text { T01-1020 } \\
\text { T01-1021 }\end{array}$ \\
\hline
\end{tabular}


Table A3. Sample information for ${ }^{36}$ chlorine depth-profile dating.-Continued

[Soil horizons designations from Soil Survey Staff, 1993. Abbreviations: NMT, New Mexico Institute of Technology; NRCS, Natural Resources Conservation Service (formerly SCS); NS, not sampled; NA, not analyzed; dup., duplicate analysis]

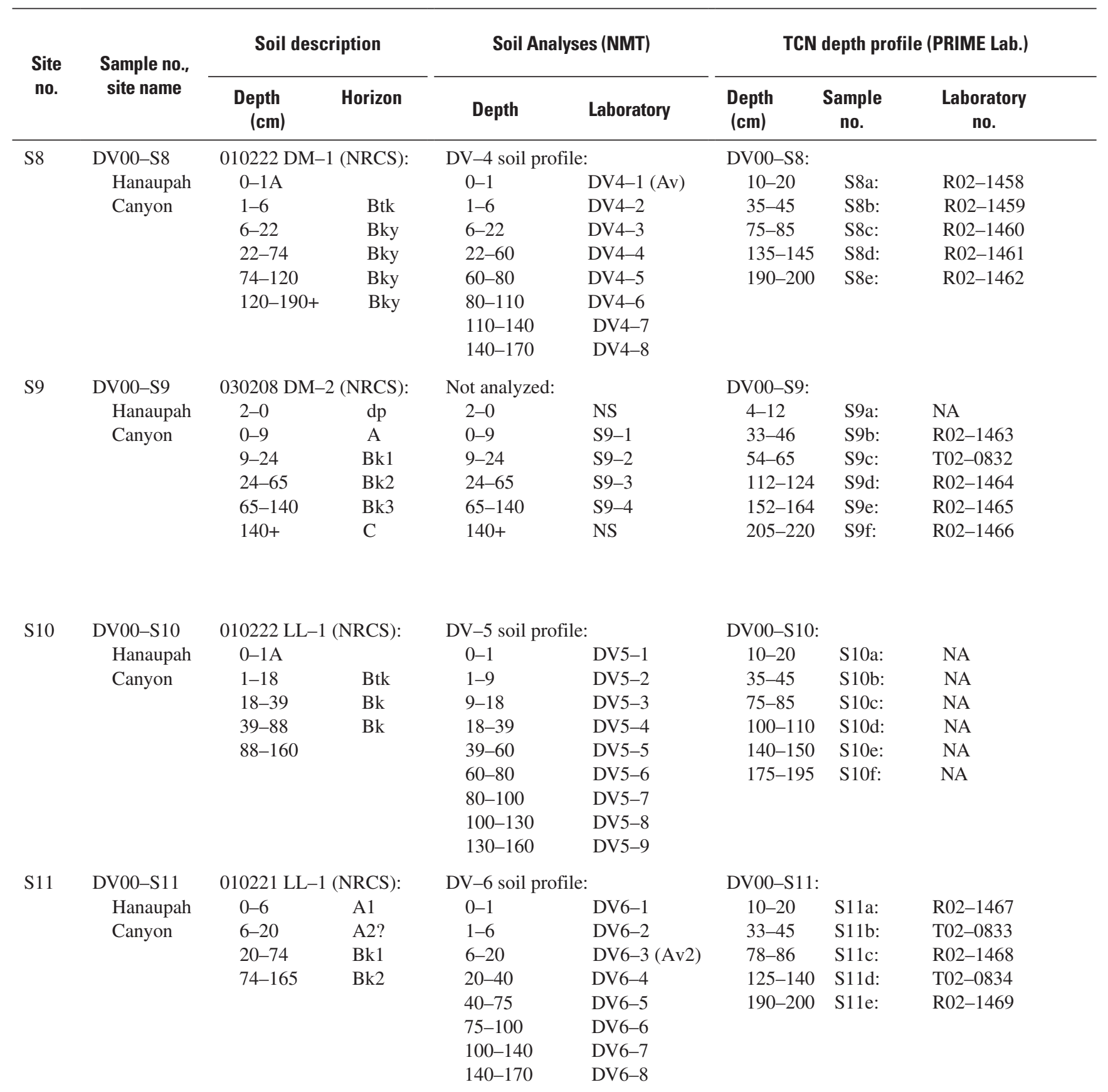


Table A3. Sample information for ${ }^{36}$ chlorine depth-profile dating-Continued.

\begin{tabular}{|c|c|c|c|c|c|c|c|c|}
\hline \multirow{2}{*}{$\begin{array}{l}\text { Site } \\
\text { no. }\end{array}$} & \multirow{2}{*}{$\begin{array}{l}\text { Sample no., } \\
\text { site name }\end{array}$} & \multicolumn{2}{|c|}{ Soil description } & \multicolumn{2}{|c|}{ Soil Analyses (NMT) } & \multicolumn{3}{|c|}{ TCN depth profile (PRIME Lab.) } \\
\hline & & Depth & (cm) & Depth & Laboratory & $\begin{array}{l}\text { Depth } \\
(\mathrm{cm})\end{array}$ & $\begin{array}{c}\text { Sample } \\
\text { no. }\end{array}$ & $\begin{array}{c}\text { Laboratory } \\
\text { no. }\end{array}$ \\
\hline $\mathrm{S} 12$ & $\begin{array}{c}\text { DV00-S12 } \\
\text { Hanaupah } \\
\text { Canyon }\end{array}$ & $\begin{array}{l}010221 \mathrm{DM} \\
0-5 \\
5-11 \\
11-71 \\
71-87 \\
87-170\end{array}$ & $\begin{array}{c}-2 \text { (NRCS): } \\
\text { A2 } \\
\text { Btk } \\
\text { Bk1 } \\
\text { Bk2 } \\
\text { Bk3 }\end{array}$ & $\begin{array}{l}\text { DV-7 soil p } \\
\quad 0-1 \\
1-5 \\
5-11 \\
11-41 \\
41-71 \\
71-81 \\
81-105 \\
105-130 \\
130-170\end{array}$ & $\begin{array}{l}\text { DV7-1 } \\
\text { DV7-2 } \\
\text { DV7-3 } \\
\text { DV7-4 } \\
\text { DV7-5 } \\
\text { DV7-6 } \\
\text { DV7-7 } \\
\text { DV7-8 } \\
\text { DV7-9 }\end{array}$ & $\begin{array}{l}\text { DV00-S12: } \\
15-23 \\
42-50 \\
63-73 \\
98-108 \\
124-136 \\
\\
190-205\end{array}$ & $\begin{array}{l}\text { S12a: } \\
\text { S12b: } \\
\text { S12c: } \\
\text { S12d: } \\
\text { S12e: } \\
\text { S12f: }\end{array}$ & $\begin{array}{l}\text { R02-1470 } \\
\text { T02-0835 } \\
\text { T02-0836 } \\
\text { R02-1471 } \\
\text { R02-1472 } \\
\text { R02-1473 (dup) } \\
\text { T02-0837 }\end{array}$ \\
\hline S14 & $\begin{array}{c}\text { DV00-S14 } \\
\text { Mile } 22 \\
\text { (Redwall } \\
\text { Canyon) }\end{array}$ & $\begin{array}{l}\text { RW4 (R. K1 } \\
\quad 2-0 \\
0-4 \\
4-16 \\
16-28 \\
28-50 \\
50-85 \\
85-160+\end{array}$ & $\begin{array}{l}\text { inger): } \\
\text { dp } \\
\text { Avk } \\
\text { Btkz } \\
2 B k 1 \\
2 B k 2 \\
2 B k y \\
2 C\end{array}$ & $\begin{array}{r}\text { Not sampled } \\
\text { analysis; } 1 \\
\text { RW-4 of }\end{array}$ & $\begin{array}{l}\text { extural } \\
\text { d near soil site } \\
\text { ser }(2003)\end{array}$ & $\begin{array}{c}\text { DV00-S14: } \\
10-16 \\
22-28 \\
45-53 \\
70-83 \\
\\
110-120 \\
150-165 \\
215-225\end{array}$ & $\begin{array}{l}\text { S14a: } \\
\text { S14b: } \\
\text { S14c: } \\
\text { S14d: } \\
\text { S14e: } \\
\text { S14f: } \\
\text { S14g: }\end{array}$ & $\begin{array}{l}\text { NA } \\
\text { T01-0990 } \\
\text { T01-0991 } \\
\text { T01-0992 } \\
\text { T01-0993 (dup) } \\
\text { T01-1022 } \\
\text { NA } \\
\text { T01-1023 }\end{array}$ \\
\hline S15 & $\begin{array}{c}\text { DV00-S15 } \\
\text { Mile } 22 \\
\text { (Redwall } \\
\text { Canyon) }\end{array}$ & $\begin{array}{l}\text { S15 profile } \\
\quad 2-0 \\
0-3 \\
3-20 \\
20-45 \\
45-90+\end{array}$ & $\begin{array}{l}\text { (Machette): } \\
\text { dp } \\
\text { Av } \\
\text { 2Btkz } \\
2 \mathrm{Bk} 1 \\
2 \mathrm{Bk} 2\end{array}$ & $\begin{array}{r}\text { Not sampled } \\
\text { analysis; } 1 \\
\text { RK-9 of } \mathrm{I}\end{array}$ & $\begin{array}{l}\text { extural } \\
\text { d near soil site } \\
\text { er }(2003)\end{array}$ & $\begin{array}{l}\text { DV00-S15: } \\
15-25 \\
50-60 \\
83-92 \\
120-130 \\
190-205\end{array}$ & $\begin{array}{l}\text { S15a: } \\
\text { S15b: } \\
\text { S15c: } \\
\text { S15d: } \\
\text { S15e: }\end{array}$ & $\begin{array}{l}\text { NA } \\
\text { NA } \\
\text { NA } \\
\text { NA } \\
\text { NA }\end{array}$ \\
\hline S16 & $\begin{array}{c}\text { DV00-S16 } \\
\text { Echo } \\
\text { Canyon }\end{array}$ & 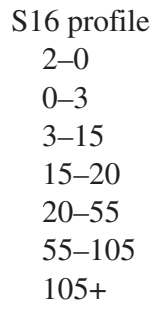 & $\begin{array}{l}\text { Machette): } \\
\text { dp } \\
\text { Av } \\
\text { Btkz } \\
\text { Btk } \\
\text { Bky } \\
\text { By } \\
\text { Cox }\end{array}$ & $\begin{array}{r}\text { Not sampled } \\
\text { analysis; } \\
\text { site RK-9 }\end{array}$ & $\begin{array}{l}\text { textural } \\
\text { ed near soil } \\
\text { Clinger (2003) }\end{array}$ & $\begin{array}{c}\text { DV00-S16: } \\
16-24 \\
38-46 \\
70-80 \\
110-120 \\
170-175\end{array}$ & $\begin{array}{l}\text { S16a: } \\
\text { S16b: } \\
\text { S16c: } \\
\text { S16d: } \\
\text { S16e: }\end{array}$ & $\begin{array}{l}\text { T02-0823 } \\
\text { T02-0824 } \\
\text { T02-0825 } \\
\text { T02-0826 } \\
\text { R02-1474 }\end{array}$ \\
\hline S17 & $\begin{array}{c}\text { DV00-S17 } \\
\quad \text { Mustard } \\
\text { Canyon } \\
\text { Hills }\end{array}$ & $\begin{array}{l}\text { S17 profile } \\
\quad 2-0 \\
\quad 0-6 \\
\quad 6-20 \\
20-55 \\
55-110 \\
110+\end{array}$ & $\begin{array}{l}\text { Machette): } \\
\text { dp } \\
\text { Av } \\
\text { Btz } \\
\text { Btk } \\
\text { Btj } \\
\text { Bk }\end{array}$ & Not sampled & extural analysis & $\begin{array}{l}\text { DV00-S17: } \\
\text { 20-28 } \\
55-65 \\
95-108 \\
140-155 \\
200-215\end{array}$ & $\begin{array}{l}\text { S17a: } \\
\text { S17b: } \\
\text { S17c: } \\
\text { S17d: } \\
\text { S17e: }\end{array}$ & $\begin{array}{l}\text { T01-0999 } \\
\text { T01-1000 } \\
\text { T01-1001 } \\
\text { T01-1002 } \\
\text { T01-1003 }\end{array}$ \\
\hline
\end{tabular}


Table A4. Characteristics of quaternary alluvial units, Death Valley, California.

[Pedologic nomenclature according to usage of Soil Survey Staff, 1993 and 1999, with modifications by Birkeland, 1999. Modified from Klinger and SarnaWojcicki, 2001, their table A3-1]

\begin{tabular}{|c|c|c|c|c|c|c|}
\hline $\begin{array}{l}\text { Map units } \\
\text { for this } \\
\text { report }\end{array}$ & $\begin{array}{l}\text { Map } \\
\text { units of } \\
\text { Klinger }^{2}\end{array}$ & $\begin{array}{c}\text { Desert varnish color; }{ }^{3} \\
\text { Desert pavement } \\
\text { development }^{4}\end{array}$ & $\begin{array}{l}\text { Bar-and-swale } \\
\text { morphology; } \\
\text { Erosional character }\end{array}$ & Typical soil profile ${ }^{5}$ & $\begin{array}{l}\text { Thickness } \\
\text { of soil; } \\
\text { PDI }^{6}\end{array}$ & $\begin{array}{l}\text { Maximum reddish soi } \\
\text { color }^{7}\end{array}$ \\
\hline Qai & Q2c & $\begin{array}{l}\text { 5YR } 5 / 8 \text { to } 2.5 \text { YR5 } 4 / 8 \text {; } \\
\text { well packed optimal } \\
\text { development, clasts } \\
\text { often split }\end{array}$ & $\begin{array}{l}\text { No morphology; } \\
\text { moderately deep } \\
\text { channels with broad } \\
\text { spacing, subtle } \\
\text { erosion }\end{array}$ & $\begin{array}{l}\text { Av, Btkz, Bz, lots } \\
\text { of silt, stage II-III } \\
\text { carbonate }\end{array}$ & $\begin{array}{l}85-100 \\
\mathrm{~cm} ; 45\end{array}$ & $7.5 \mathrm{YR} 5 / 6$ \\
\hline $\begin{array}{l}\text { Qaio } \\
\text { (older } \\
\text { subunit } \\
\text { of Qai) }\end{array}$ & Q2b & $\begin{array}{l}2.5 \text { YR } 4 / 8 \text {; well packed, } \\
\text { locally eroded or } \\
\text { disturbed }\end{array}$ & $\begin{array}{l}\text { No morphology; } \\
\text { deeply incised } \\
\text { channels, } \\
\text { moderately eroded }\end{array}$ & $\begin{array}{l}\text { Av, Btkz, Bz, lots } \\
\text { of silt, carbonate } \\
\text { Stage III }\end{array}$ & $\begin{array}{l}140 \mathrm{~cm} \\
>45\end{array}$ & $7.5 \mathrm{YR} 5 / 6$ \\
\hline Qao & Q2a & $\begin{array}{l}\text { Clasts disturbed; locally } \\
\text { well packed, pavement } \\
\text { mostly eroded }\end{array}$ & $\begin{array}{l}\text { No morphology; very } \\
\text { deeply incised } \\
\text { channels and } \\
\text { eroded; K horizon } \\
\text { at surface }\end{array}$ & $\begin{array}{l}\text { Btkz, Bz, lots of } \\
\text { silt, stage III-VI } \\
\text { carbonate }\end{array}$ & $\begin{array}{l}150-200 \\
\mathrm{~cm}, \text { eroded }\end{array}$ & $\begin{array}{l}\text { Typically white ( } \mathrm{K} \\
\text { horizon) }\end{array}$ \\
\hline QTa & Q1 & $\begin{array}{l}\text { Clasts disturbed; locally } \\
\text { well packed, pavement } \\
\text { mostly eroded }\end{array}$ & $\begin{array}{l}\text { No morphology; } \\
\text { deeply incised, } \\
\text { ballina landforms, } \\
\text { eroded K horizon at } \\
\text { surface }\end{array}$ & $\begin{array}{l}\text { Eroded Bk or Bkz, } \\
\text { stage III-VI ca } \\
\text { bonate }\end{array}$ & $\begin{array}{l}\text { Much } \\
\text { eroded; } \\
\text { variable }\end{array}$ & $\begin{array}{l}\text { Typically white ( } \mathrm{K} \\
\text { horizon) }\end{array}$ \\
\hline
\end{tabular}

${ }^{1}$ Map units used in this report (based on Slate and others, in press).

${ }^{2}$ Map units used by Klinger and Sarna-Wojcicki, 2001.

${ }^{3}$ Dry color of basal surface of undisturbed clasts using Munsell Color Chart (Munsell Color Co., Baltimore, Md., 1975 ed.).

${ }^{4}$ Pavement development based on degree of packing and is dependent on clast lithology.

${ }^{5}$ From Klinger and Sarna-Wojcicki, 2001, their table A3-1 and our observations from trenching and mapping.

${ }^{6} \mathrm{PDI}$ values (profile development index of Harden and Taylor, 1983) are from Klinger and Sarna-Wojcicki, 2001, following methods shown in their table A3-1.

${ }^{7}$ Dry color of $<2-\mathrm{mm}$ soil fraction using Munsell Color Chart (Munsell Color Co., Baltimore, Maryland, 1975 ed.). 
Table A5. Soil parameters for calculating bulk density.

[USGS, U.S. Geological Survey; NMT, New Mexico Institute of Technology, NRCS, National Resource Conservation Service; Vol. RF, volume of rock fragments; Calc. BD, calculated bulk density for whole soil; g/cc, grams pers cubic centimeter. Values in gray are estimated]

\begin{tabular}{|c|c|c|c|c|c|c|c|c|c|}
\hline \multirow{2}{*}{$\begin{array}{l}\text { USGS sample } \\
\text { number and } \\
\text { depth }(\mathrm{cm})\end{array}$} & \multirow{2}{*}{$\begin{array}{c}\text { NMT } \\
\text { laboratory } \\
\text { number }\end{array}$} & \multicolumn{3}{|c|}{ Particle size analysis (<2 mm) } & \multirow{2}{*}{$\begin{array}{l}\text { Average } \\
\text { bulk } \\
\text { density } \\
\text { (g/cc) }\end{array}$} & \multirow{2}{*}{$\begin{array}{c}\mathrm{CaCO}_{3} \\
\text { content } \\
\text { (percent) }\end{array}$} & \multicolumn{3}{|c|}{ Particle density = $2.65 \mathrm{~g} / \mathrm{cc}$} \\
\hline & & $\begin{array}{c}\text { Sand } \\
\text { (percent) }\end{array}$ & $\begin{array}{c}\text { Silt } \\
\text { (percent) }\end{array}$ & $\begin{array}{c}\text { Clay } \\
\text { (percent) }\end{array}$ & & & $\begin{array}{c}\text { Vol. } \\
\text { RF }\end{array}$ & $\begin{array}{c}>2 \mathrm{~mm} \\
\text { (percent) }\end{array}$ & $\begin{array}{c}\text { Calc. } \\
\text { BD (g/cc) }\end{array}$ \\
\hline $\mathbf{A}$ & B & C & D & $\mathbf{E}$ & $\mathbf{F}$ & G & $\mathbf{I}$ & G & H \\
\hline DV-S2, AV 0-15 & DV1-1 & 19.6 & 69.2 & 11.1 & 1.56 & 14.95 & 38.6 & 51.6 & 2.1 \\
\hline DV-S2, 15-30 & DV1-2 & 54.6 & 36.1 & 9.3 & 1.31 & 13.51 & 62.6 & 77.2 & 2.3 \\
\hline DV-S2, 30-50 & DV1-3 & 62.7 & 28.3 & 9.0 & 1.57 & 18.2 & 65.0 & 75.8 & 2.4 \\
\hline DV-S2, 50-80 & DV1-4 & 60.9 & 31.4 & 7.7 & 1.58 & 15.92 & 64.0 & 74.9 & 2.4 \\
\hline DV-S2, 80-110 & DV1-5 & 40.5 & 44.3 & 15.2 & 1.27 & 16.36 & 65.0 & 79.5 & 2.4 \\
\hline DV-S2, 110-140 & DV1-6 & 41.3 & 46.0 & 12.7 & 1.47 & 12.31 & 65.8 & 77.6 & 2.4 \\
\hline DV-S2, 140-170 & DV1-7 & 61.0 & 33.8 & 5.2 & 1.65 & & 68.0 & 77.3 & 2.4 \\
\hline DV-S6, 0-1 & DV 2-1 & 65.2 & 29.7 & 5.1 & 1.66 & 4.9 & 95.5 & 97.1 & 2.6 \\
\hline DV-S6, 1-5 & DV 2-2 & 51.2 & 35.8 & 13.0 & 1.61 & 7.8 & 27.0 & 37.8 & 2.0 \\
\hline DV-S6, 5-15 & DV 2-3 & 35.3 & 52.8 & 11.8 & 1.78 & 10.74 & 22.0 & 29.6 & 2.0 \\
\hline DV-S6, 15-30 & DV 2-4 & 53.3 & 35.8 & 11.0 & 1.52 & 4.21 & 73.0 & 82.5 & 2.5 \\
\hline DV-S6, 30-50 & DV 2-5 & 58.8 & 31.7 & 9.5 & 1.4 & 2.93 & 73.0 & 83.7 & 2.4 \\
\hline DV-S6, 50-70 & DV 2-6 & 56.0 & 34.5 & 9.5 & 1.53 & 2.83 & 73.0 & 82.4 & 2.5 \\
\hline DV-S6, 70-90 & DV 2-7 & 50.4 & 36.9 & 12.6 & 1.49 & 2.53 & 73.0 & 82.8 & 2.5 \\
\hline DV-S6, 90-110 & DV 2-8 & 58.7 & 28.5 & 12.8 & 1.51 & & 73.0 & 82.6 & 2.5 \\
\hline DV-S6, 110-140 & DV 2-9 & 47.6 & 39.2 & 13.2 & 1.49 & 6.37 & 73.0 & 82.8 & 2.5 \\
\hline DV-S6, 140-160 & DV 2-10 & 60.5 & 29.1 & 10.3 & 1.55 & 5.98 & 73.0 & 82.2 & 2.5 \\
\hline DV-S7, 0-1 & DV3-1 & 70.6 & 27.9 & 1.5 & 1.8 & 5.09 & 95.0 & 96.5 & 2.6 \\
\hline DV-S7, 1-8 & DV3-2 & 44.2 & 46.6 & 9.2 & 1.53 & 8.76 & 23.6 & 34.9 & 1.9 \\
\hline DV-S,7 8-21 & DV3-3 & 33.9 & 44.3 & 21.9 & 1.33 & 7.17 & 30.0 & 46.1 & 1.9 \\
\hline DV-S7, 21-58 & DV3-4 & 56.5 & 21.9 & 21.6 & 1.43 & 4.82 & 85.0 & 91.3 & 2.5 \\
\hline DV-S7, 58-90 & DV3-5 & 62.0 & 24.6 & 13.4 & 1.50 & 1.26 & 77.0 & 85.5 & 2.5 \\
\hline DV-S7, 90-120 & DV3-6 & 61.3 & 24.8 & 13.9 & 1.50 & 3.39 & 77.0 & 85.5 & 2.5 \\
\hline DV-S7, 120-150 & DV3-7 & 73.1 & 18.8 & 8.2 & 1.61 & 6.35 & 77.0 & 84.6 & 2.5 \\
\hline DV-S7, 150-170 & DV3-8 & 64.2 & 23.2 & 12.7 & 1.52 & 2.41 & 77.0 & 85.4 & 2.5 \\
\hline DV-S8, 0-1 & DV4-1 & 58.3 & 36.7 & 5.0 & 1.65 & 5.4 & 95.5 & 97.1 & 2.6 \\
\hline DV-S8, 1-6 & DV4-2 & 33.4 & 41.7 & 24.9 & 1.69 & 15.3 & 5.0 & 7.6 & 1.8 \\
\hline DV-S8, 6-22 & DV4-3 & 39.2 & 51.9 & 9.0 & 1.52 & 4.84 & 5.0 & 8.4 & 1.6 \\
\hline DV-S8, 22-60 & DV4-4 & 34.5 & 56.6 & 8.9 & 1.51 & 7.44 & 50.0 & 63.7 & 2.2 \\
\hline DV-S8, 60-80 & DV4-5 & 35.0 & 56.5 & 8.5 & 1.51 & 6.44 & 54.1 & 67.4 & 2.3 \\
\hline DV-S8, 80-110 & DV4-6 & 35.2 & 56.8 & 8.1 & 1.58 & 5.64 & 55.0 & 67.2 & 2.3 \\
\hline DV-S8, 110-140 & DV4-7 & 46.6 & 45.3 & 8.1 & 1.56 & 5.04 & 48.3 & 61.3 & 2.2 \\
\hline DV-S8, 140-170 & DV4-8 & 50.5 & 41.7 & 7.9 & 1.5 & 6.44 & 45.0 & 59.1 & 2.2 \\
\hline DV-S10, 0-1 & DV5-1 & 59.7 & 34.9 & 5.4 & 1.62 & 4.13 & 94.5 & 96.6 & 2.6 \\
\hline DV-S10, 1-9 & DV5-2 & 78.2 & 4.6 & 17.2 & 1.53 & 14.06 & 20.0 & 30.2 & 1.9 \\
\hline DV-S10, 9-18 & DV5-3 & 32.9 & 49.2 & 18.0 & 1.45 & 9.66 & 20.0 & 31.4 & 1.8 \\
\hline DV-S10, 18-39 & DV5-4 & 34.9 & 55.4 & 9.8 & 1.50 & 11.39 & 48.0 & 62.0 & 2.2 \\
\hline
\end{tabular}


Table A5. Soil parameters for calculating bulk density.-Continued

[USGS, U.S. Geological Survey; NMT, New Mexico Institute of Technology, NRCS, National Resource Conservation Service; Vol. RF, volume of rock fragments; Calc. BD, calculated bulk density for whole soil; g/cc, grams pers cubic centimeter. Values in gray are estimated

\begin{tabular}{|c|c|c|c|c|c|c|c|c|c|}
\hline \multirow{2}{*}{$\begin{array}{c}\text { USGS sample } \\
\text { number and } \\
\text { depth }(\mathrm{cm})\end{array}$} & \multirow{2}{*}{$\begin{array}{c}\text { NMT } \\
\text { laboratory } \\
\text { number }\end{array}$} & \multicolumn{3}{|c|}{ Particle size analysis ( $<2 \mathrm{~mm}$ ) } & \multirow{2}{*}{$\begin{array}{l}\text { Average } \\
\text { bulk } \\
\text { density } \\
\text { (g/cc) }\end{array}$} & \multirow{2}{*}{$\begin{array}{c}\mathrm{CaCO}_{3} \\
\text { content } \\
\text { (percent) }\end{array}$} & \multicolumn{3}{|c|}{ Particle density = $2.65 \mathrm{~g} / \mathrm{cc}$} \\
\hline & & $\begin{array}{c}\text { Sand } \\
\text { (percent) }\end{array}$ & $\begin{array}{c}\text { Silt } \\
\text { (percent) }\end{array}$ & $\begin{array}{c}\text { Clay } \\
\text { (percent) }\end{array}$ & & & $\begin{array}{l}\text { Vol. } \\
\text { RF }\end{array}$ & $\begin{array}{c}>2 \mathrm{~mm} \\
\text { (percent) }\end{array}$ & $\begin{array}{c}\text { Calc. } \\
\text { BD (g/cc) }\end{array}$ \\
\hline A & B & C & D & $\mathbf{E}$ & $\mathbf{F}$ & $\mathbf{G}$ & $\mathbf{I}$ & $\mathbf{G}$ & H \\
\hline DV-S10, 39-60 & DV5-5 & 35.4 & 57.0 & 7.7 & 1.53 & 7.56 & 48.0 & 61.5 & 2.2 \\
\hline DV-S10, 60-80 & DV5-6 & 40.7 & 52.4 & 7.0 & 1.52 & 4.63 & 48.0 & 61.7 & 2.2 \\
\hline DV-S10, 80-100 & DV5-7 & 42.2 & 50.9 & 6.9 & 1.64 & 3.9 & 45.6 & 57.5 & 2.2 \\
\hline DV-S10, 100-130 & DV5-8 & 37.9 & 54.0 & 8.0 & 1.65 & 5.62 & 44.0 & 55.8 & 2.2 \\
\hline DV-S10, 130-160 & DV5-9 & 44.9 & 47.8 & 7.3 & 1.46 & 5.33 & 44.0 & 58.8 & 2.2 \\
\hline DV-S11, 0-1 & DV6-1 & 52.3 & 41.4 & 6.3 & 1.61 & & 95 & 96.9 & 2.6 \\
\hline DV-S11, 1-6 & DV6-2 & 31.7 & 49.5 & 18.8 & 1.22 & 17.52 & 10 & 19.4 & 1.5 \\
\hline DV-S11, 6-20 & DV6-3 & 43.0 & 35.1 & 21.9 & 1.56 & 8.69 & 48 & 61.1 & 2.2 \\
\hline DV-S11, 20-40 & DV6-4 & 51.1 & 37.1 & 11.8 & 1.5 & 4.61 & 60 & 72.6 & 2.3 \\
\hline DV-S11, 40-75 & DV6-5 & 53.0 & 35.6 & 11.4 & 1.51 & & 60.3 & 72.7 & 2.3 \\
\hline DV-S11, 75-100 & DV6-6 & 69.6 & 21.4 & 8.9 & 1.58 & 6.18 & 71 & 80.4 & 2.4 \\
\hline DV-S11, 100-140 & DV6-7 & 41.4 & 48.1 & 10.5 & 1.5 & 15.17 & 71 & 81.2 & 2.4 \\
\hline DV-S11, 140-170 & DV6-8 & 60.3 & 33.4 & 6.4 & 1.6 & 10.88 & 71 & 80.2 & 2.4 \\
\hline DV-S12, 0-1 & DV7-1 & 55.8 & 39.0 & 5.2 & 1.47 & & 80.0 & 87.8 & 2.5 \\
\hline DV-S12, 1-5 & DV7-2 & 28.8 & 60.1 & 11.2 & 1.44 & 5.56 & 10.0 & 17.0 & 1.6 \\
\hline DV-S12, 5-11 & DV7-3 & 36.6 & 52.3 & 11.1 & 1.76 & 11.92 & 30.0 & 39.2 & 2.1 \\
\hline DV-S12, 11-41 & DV7-4 & 41.3 & 54.1 & 4.6 & 1.61 & 7.64 & 70.0 & 79.3 & 2.4 \\
\hline DV-S12, 41-71 & DV7-5 & 41.9 & 51.5 & 6.6 & 1.55 & 5.93 & 70.0 & 80.0 & 2.4 \\
\hline DV-S12, 71-81 & DV7-6 & 54.3 & 38.9 & 6.8 & 1.1 & 5.48 & 75.0 & 87.8 & 2.5 \\
\hline DV-S12, 81-105 & DV7-7 & 80.0 & 8.4 & 11.6 & 1.33 & 4.88 & 48.8 & 65.5 & 2.2 \\
\hline DV-S12, 105-130 & DV7-8 & 43.4 & 49.8 & 6.9 & 1.35 & 4.1 & 40.0 & 56.7 & 2.1 \\
\hline DV-S12, 130-170 & DV7-9 & 53.9 & 40.3 & 5.8 & 1.53 & 6.71 & 40.0 & 53.6 & 2.1 \\
\hline
\end{tabular}


Table A6. Bulk-density calculations for depth-profile samples.

[Soil-horizon nomenclature from Soil Survey Staff, 1993 and 1999, and Birkeland, 1999, with these exceptions: dp, desert pavement; Av, vesicular A. Abbreviations: BD, bulk density; NA, not applicable or available; e, estimated value; $\mathrm{g} / \mathrm{cm}^{2}$, grams per square centimeter; $\mathrm{g} / \mathrm{cm}^{3}$, grams per cubic centimeter]

\begin{tabular}{|c|c|c|c|c|c|c|c|c|c|c|c|}
\hline \multirow[t]{2}{*}{$\begin{array}{l}\text { Site } \\
\text { no. }\end{array}$} & \multicolumn{2}{|c|}{$\begin{array}{l}\text { Depth for soil } \\
\text { horizon }\end{array}$} & \multicolumn{2}{|c|}{$\begin{array}{l}\text { Soil bulk density } \\
\text { (BD) }\left(\mathrm{g} / \mathrm{cm}^{3}\right)\end{array}$} & \multicolumn{3}{|c|}{$\begin{array}{l}\text { Sampling depth (cm), } \\
\text { soil sample no., } \\
\text { and Prime Laboratory no. }\end{array}$} & \multirow{2}{*}{$\begin{array}{l}\text { Thicknesses }(\mathbf{c m}) \text { and bulk densities } \\
\left(\mathbf{g} / \mathbf{c m}^{3}\right) \text { above sample }\end{array}$} & \multirow{2}{*}{$\begin{array}{c}\begin{array}{c}\text { Mass } \\
\text { above }\end{array} \\
\text { sample } \\
\left(\mathbf{g} / \mathbf{c m}^{2}\right)\end{array}$} & \multicolumn{2}{|c|}{$\begin{array}{l}\text { Average BD and } \\
\text { thickness } \\
\text { above sample }\end{array}$} \\
\hline & $0-6$ & A1 & $0-15$ & 2.1 & $10-16$ & S2a: & T01-1009 & & & 2.10 & (13) \\
\hline & $6-16$ & $\mathrm{~A} 2$ & $15-30$ & 2.3 & $30-38$ & S2b: & T01-1010 & $15 \times 2.1+15 \times 2.3+4 \times 2.4$ & 75.6 & 2.22 & (34) \\
\hline & $16-74$ & Bky & $30-170$ & 2.4 & $60-68$ & S2c: & T01-1011 & $15 \times 2.1+15 \times 2.3+34 \times 2.4$ & 147.6 & 2.31 & (63) \\
\hline & $74-125$ & Bky & & & $90-110$ & S2d: & T01-1012 & $15 \times 2.1+15 \times 2.3+70 \times 2.4$ & 234.0 & 2.34 & $(100)$ \\
\hline & $125-170+$ & Bky & & & $132-145$ & S2e: & T01-1013 & $15 \times 2.1+15 \times 2.3+108.5 \times 2.4$ & 326.4 & 2.36 & $(138.5)$ \\
\hline & & & & & $175-185$ & S2f: & T01-1014 & $15 \times 2.1+15 \times 2.3+150 \times 2.4$ & 426.0 & 2.37 & $(180)$ \\
\hline \multirow[t]{8}{*}{ S5 } & $2-0$ & $\mathrm{dp}$ & $2-0$ & $2.6 \mathrm{e}$ & $5-15$ & S5f: & T01-0947 & $2 \times 2.6+7 \times 1.8+1 \times 1.9$ & 19.7 & 1.64 & (12) \\
\hline & $0-7$ & A & $0-7$ & $1.8 \mathrm{e}$ & $45-55$ & S5e: & T01-0946 & $2 \times 2.6+7 \times 1.8+15 \times 1.9+22 \times 2.3+6 \times 2.4$ & 111.3 & 2.14 & $(52)$ \\
\hline & $7-22$ & Bk1 & $7-22$ & $1.9 \mathrm{e}$ & $65-75$ & S5d: & NA & $2 \times 2.6+7 \times 1.8+15 \times 1.9+22 \times 2.3+26 \times 2.4$ & 159.3 & 2.21 & $(72)$ \\
\hline & $22-44$ & $\mathrm{Bk} 2$ & $22-44$ & $2.3 \mathrm{e}$ & $100-110$ & S5c: & T01-0945 & $2 \times 2.6+7 \times 1.8+15 \times 1.9+22 \times 2.3+61 \times 2.4$ & 243.3 & 2.27 & (107) \\
\hline & $44-100$ & $\mathrm{Bk} 3$ & $44-100+$ & $2.4 \mathrm{e}$ & $150-160$ & S5b: & NA & $2 \times 2.6+7 \times 1.8+15 \times 1.9+22 \times 2.3+111 \times 2.4$ & 363.3 & 2.31 & (157) \\
\hline & $100+$ & $\mathrm{C}$ & & & $200-210$ & S5a: & T01-0944 & $2 \times 2.6+7 \times 1.8+15 \times 1.9+22 \times 2.3+161 \times 2.4$ & 483.3 & 2.33 & (207) \\
\hline & & & & & $400 \pm$ & S5g: & T01-0948 & $2 \times 2.6+7 \times 1.8+15 \times 1.9+22 \times 2.3+356 \times 2.4$ & 951.3 & 2.37 & $(402)$ \\
\hline & & & & & $700 \pm$ & S5h: & NA & & & & \\
\hline \multirow[t]{7}{*}{ S6 } & $0-3$ & Aky & $0-1$ & 2.6 & $13-21$ & S6a: & T02-0827 & $1 \times 2.6+14 \times 2.0+2 \times 2.5$ & 35.6 & 2.09 & (17) \\
\hline & $3-15$ & Btkyz & $1-5$ & 2.0 & $41-53$ & S6b: & T02-0828 & $1 \times 2.6+14 \times 2.0+32 \times 2.5$ & 110.6 & 2.35 & (47) \\
\hline & $15-40$ & Bkyzl & $5-15$ & 2.0 & $72-84$ & S6c: & T02-0829 \& (dup) & $1 \times 2.6+14 \times 2.0+63 \times 2.5$ & 188.1 & 2.41 & (78) \\
\hline & $40-168+$ & Bkyz2 & $15-30$ & 2.5 & $106-118$ & S6d: & T02-0830 & $1 \times 2.6+14 \times 2.0+97 \times 2.5$ & 273.1 & 2.44 & (112) \\
\hline & & & $30-50$ & 2.4 & $140-155$ & S6e: & T02-0831 & $1 \times 2.6+14 \times 2.0+132.5 \times 2.5$ & 361.8 & 2.45 & $(147.5)$ \\
\hline & & & $50-160$ & 2.5 & $195-205$ & S6f: & NA & $1 \times 2.6+14 \times 2.0+185 \times 2.5$ & 493.1 & 2.47 & $(200)$ \\
\hline & & & $160-200$ & $2.5 \mathrm{e}$ & & & & & & & \\
\hline \multirow[t]{6}{*}{ S7 } & $0-4$ & A & $0-1$ & 2.6 & $8-15$ & S7a: & T01-1015 & $1 \times 2.6+10.5 \times 1.9$ & 22.6 & 1.97 & $(11.5)$ \\
\hline & $4-21$ & Btky & $1-8$ & 1.9 & $22-35$ & S7b: & T01-1016 \& (dup) & $1 \times 2.6+20 \times 1.9+7.5 \times 2.5$ & 59.4 & 2.08 & $(28.5)$ \\
\hline & $21-58$ & Bkyq & $8-21$ & 1.9 & $72-82$ & S7c: & T01-1018 & $1 \times 2.6+20 \times 1.9+56 \times 2.5$ & 180.6 & 2.35 & (77) \\
\hline & $58-120$ & Bky & $21-170$ & 2.5 & $96-106$ & S7d: & T01-1019 & $1 \times 2.6+20 \times 1.9+80 \times 2.5$ & 240.6 & 2.38 & $(101)$ \\
\hline & $120-190+$ & $\mathrm{Bk}$ & $170-200$ & $2.5 \mathrm{e}$ & $155-165$ & S7e: & T01-1020 & $1 \times 2.6+20 \times 1.9+139 \times 2.5$ & 388.1 & 2.43 & $(160)$ \\
\hline & & & & & 190-202 & S7f: & T01-1021 & $1 \times 2.6+20 \times 1.9+175 \times 2.5$ & 478.1 & 2.44 & (196) \\
\hline \multirow[t]{7}{*}{ S8 } & $0-1$ & Av & $0-1$ & 2.6 & $10-20$ & S8a: & R02-1458 & $1 \times 2.6+5 \times 1.8+9 \times 1.6$ & 26.0 & 1.73 & (15) \\
\hline & $1-6$ & Btk & $1-6$ & 1.8 & $35-45$ & S8b: & R02-1459 & $1 \times 2.6+5 \times 1.8+16 \times 1.6+18 \times 2.2$ & 76.8 & 1.92 & (40) \\
\hline & $6-22$ & Bky & $6-22$ & 1.6 & $75-85$ & S8c: & R02-1460 & $1 \times 2.6+5 \times 1.8+16 \times 1.6+38 \times 2.2+20 \times 2.3$ & 166.8 & 2.09 & $(80)$ \\
\hline & $22-74$ & Bky & $22-60$ & 2.2 & $135-145$ & S8d: & R02-1461 & $1 \times 2.6+5 \times 1.8+16 \times 1.6+38 \times 2.2+50 \times 2.3+$ & 301.8 & 2.16 & $(140)$ \\
\hline & $74-120$ & Bky & $60-110$ & 2.3 & 190-200 & S8e: & R02-1462 & $30 \times 2.2$ & 425.3 & 2.18 & (195) \\
\hline & $120-190+$ & Bky & $110-170$ & 2.2 & & & & $1 \times 2.6+5 \times 1.8+16 \times 1.6+38 \times 2.2+50 \times 2.3+60$ & & & \\
\hline & & & $170-200$ & $2.3 \mathrm{e}$ & & & & x $2.2+25 \times 2.3$ & & & \\
\hline
\end{tabular}


Table A6. Bulk-density calculations for depth-profile samples.-Continued

[Soil-horizon nomenclature from Soil Survey Staff, 1993 and 1999, and Birkeland, 1999, with these exceptions: dp, desert pavement; Av, vesicular A. Abbreviations: BD, bulk density; NA, not applicable or available; e, estimated value; $\mathrm{g} / \mathrm{cm}^{2}$, grams per square centimeter; $\mathrm{g} / \mathrm{cm}^{3}$, grams per cubic centimeter]

\begin{tabular}{|c|c|c|c|c|c|c|c|c|c|c|c|}
\hline \multirow[t]{2}{*}{$\begin{array}{l}\text { Site } \\
\text { no. }\end{array}$} & \multicolumn{2}{|c|}{$\begin{array}{l}\text { Depth for soil } \\
\text { horizon }\end{array}$} & \multicolumn{2}{|c|}{$\begin{array}{l}\text { Soil bulk } \\
\text { density (BD) } \\
\left(\mathrm{g} / \mathrm{cm}^{3}\right)\end{array}$} & \multicolumn{3}{|c|}{$\begin{array}{l}\text { Sampling depth }(\mathrm{cm}), \text { soil sample no., } \\
\text { and Prime Laboratory no. }\end{array}$} & \multirow{2}{*}{$\begin{array}{l}\begin{array}{c}\text { Thicknesses }(\mathbf{c m}) \text { and bulk densities } \\
\left(\mathbf{g} / \mathbf{c m}^{3}\right) \text { above sample }\end{array} \\
2 \times 2.6+8 \times 1.8\end{array}$} & \multirow[t]{2}{*}{ 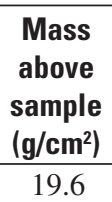 } & \multicolumn{2}{|c|}{$\begin{array}{l}\text { Average BD and } \\
\text { thickness } \\
\text { above sample }\end{array}$} \\
\hline & $2-0$ & $\mathrm{dp}$ & $2-0$ & $2.6 \mathrm{e}$ & $4-12$ & S9a: & NA & & & 1.96 & (10) \\
\hline & $0-9$ & A & $0-9$ & $1.8 \mathrm{e}$ & $33-46$ & S9b: & R02-1463 & $2 \times 2.6+9 \times 1.8+15 \times 2.4+15.5 \times 2.3$ & 91.3 & 2.20 & $(41.5)$ \\
\hline & $9-24$ & Bk1 & $9-24$ & $2.4 \mathrm{e}$ & $54-65$ & S9c: & Т02-0832 & $2 \times 2.6+9 \times 1.8+15 \times 2.4+35.5 \times 2.3$ & 137.3 & 2.23 & $(61.5)$ \\
\hline & $24-65$ & $\mathrm{Bk} 2$ & $24-65$ & $2.3 \mathrm{e}$ & $112-124$ & S9d: & R02-1464 & $2 \times 2.6+9 \times 1.8+15 \times 2.4+41 \times 2.3+53 \times 2.4$ & 277.2 & 2.31 & $(120)$ \\
\hline & $65-140$ & $\mathrm{Bk} 3$ & $65-140+$ & $2.4 \mathrm{e}$ & $152-164$ & S9e: & R02-1465 & $2 \times 2.6+9 \times 1.8+15 \times 2.4+41 \times 2.3+93 \times 2.4$ & 373.2 & 2.33 & $(160)$ \\
\hline & $140+$ & $\mathrm{C}$ & & & $205-220$ & S9f: & R02-1466 & $\begin{array}{l}2 \times 2.6+9 \times 1.8+15 \times 2.4+41 \times 2.3+147.5 \times \\
\quad 2.4\end{array}$ & 504 & 2.35 & $(214.5)$ \\
\hline \multirow[t]{6}{*}{ S10 } & $0-1$ & A & $0-1$ & 2.6 & $10-20$ & S10a: & NA & $1 \times 2.6+8 \times 1.9+6 \times 1.8$ & 28.6 & 1.91 & $(15)$ \\
\hline & $1-18$ & Btk & $1-9$ & 1.9 & $35-45$ & S10b: & NA & $1 \times 2.6+8 \times 1.9+9 \times 1.8+22 \times 2.2$ & 82.4 & 2.06 & $(40)$ \\
\hline & $18-39$ & $\mathrm{Bk}$ & $9-18$ & 1.8 & $75-85$ & S10c: & NA & $1 \times 2.6+8 \times 1.9+9 \times 1.8+62 \times 2.2$ & 170.4 & 2.13 & (80) \\
\hline & $39-88$ & $\mathrm{Bk}$ & $18-160$ & 2.2 & $100-110$ & S10d: & NA & $1 \times 2.6+8 \times 1.9+9 \times 1.8+87 \times 2.2$ & 225.4 & 2.15 & $(105)$ \\
\hline & $88-160$ & & $160-200$ & $2.2 \mathrm{e}$ & $140-150$ & S10e: & NA & $1 \times 2.6+8 \times 1.9+9 \times 1.8+127 \times 2.2$ & 313.4 & 2.16 & $(145)$ \\
\hline & & & & & $175-195$ & S10f: & NA & $1 \times 2.6+8 \times 1.9+9 \times 1.8+167 \times 2.2$ & 401.4 & 2.17 & $(185)$ \\
\hline \multirow[t]{6}{*}{ S11 } & $0-6$ & A1 & $0-1$ & 2.6 & $10-20$ & S11a: & R02-1467 & $1 \times 2.6+5 \times 1.5+9 \times 2.2$ & 29.9 & 1.99 & (15) \\
\hline & $6-20$ & A2? & $1-6$ & 1.5 & $33-45$ & S11b: & T02-0833 & $1 \times 2.6+5 \times 1.5+14 \times 2.2+19 \times 2.3$ & 84.6 & 2.17 & (39) \\
\hline & $20-74$ & Bk1 & $6-20$ & 2.2 & $78-86$ & S11c: & R02-1468 & $1 \times 2.6+5 \times 1.5+14 \times 2.2+55 \times 2.3+7 \times 2.4$ & 184.2 & 2.25 & $(82)$ \\
\hline & $74-165$ & $\mathrm{Bk} 2$ & $20-75$ & 2.3 & $125-140$ & S11d: & T02-0834 & $1 \times 2.6+5 \times 1.5+14 \times 2.2+55 \times 2.3+57.5 \times 2.4$ & 305.4 & 2.31 & $(132.5)$ \\
\hline & & & $75-170$ & 2.4 & 190-200 & S11e: & R02-1469 & $1 \times 2.6+5 \times 1.5+14 \times 2.2+55 \times 2.3+120 \times 2.4$ & 455.4 & 2.34 & $(195)$ \\
\hline & & & $170-200$ & $2.4 \mathrm{e}$ & & & & & & & \\
\hline \multirow[t]{8}{*}{$\mathrm{S} 12$} & $0-5$ & A2 & $0-1$ & 2.5 & $15-23$ & S12a: & R02-1470 & $1 \times 2.5+4 \times 1.6+6 \times 2.1+8 \times 2.4$ & 40.7 & 2.14 & (19) \\
\hline & $5-11$ & Btk & $1-5$ & 1.6 & $42-50$ & S12b: & Т02-0835 & $1 \times 2.5+4 \times 1.6+6 \times 2.1+35 \times 2.4$ & 105.5 & 2.29 & (46) \\
\hline & $11-71$ & Bk1 & $5-11$ & 2.1 & $63-73$ & S12c: & T02-0836 & $1 \times 2.5+4 \times 1.6+6 \times 2.1+57 \times 2.4$ & 158.3 & 2.33 & $(68)$ \\
\hline & $71-87$ & $\mathrm{Bk} 2$ & $11-71$ & 2.4 & $98-108$ & S12d: & R02-1471 & $1 \times 2.5+4 \times 1.6+6 \times 2.1+60 \times 2.4+10 \times 2.5+22$ & 238.9 & 2.32 & $(103)$ \\
\hline & $87-170$ & $\mathrm{Bk} 3$ & $71-81$ & 2.5 & $124-136$ & S12e: & R02-1472 & x 2.2 & 295.8 & 2.28 & $(130)$ \\
\hline & & & $81-105$ & 2.2 & & & and R02-1473 (dup) & $1 \times 2.5+4 \times 1.6+6 \times 2.1+60 \times 2.4+10 \times 2.5+24$ & 437.6 & 2.22 & $(197.5)$ \\
\hline & & & $105-170$ & 2.1 & 190-205 & S12f: & T02-0837 & $\times 2.2+25 \times 2.1$ & & & \\
\hline & & & 170-205 & 2.2 & & & & $\begin{array}{l}1 \times 2.5+4 \times 1.6+6 \times 2.1+60 \times 2.4+10 \times 2.5+24 \\
\quad \times 2.2+65 \times 2.1+27.5 \times 2.1\end{array}$ & & & \\
\hline \multirow[t]{8}{*}{ S14 } & $0-4$ & Avk & $2-0$ & $2.6 \mathrm{e}$ & $10-16$ & S14a: & NA & $2 \times 2.6+4 \times 1.7+9 \times 1.8$ & 27.0 & 1.80 & $(15)$ \\
\hline & $4-16$ & Btkz & $0-4$ & $1.7 \mathrm{e}$ & $22-28$ & S14b: & T01-0990 & $2 \times 2.6+4 \times 1.7+12 \times 1.8+9 \times 2.2$ & 52.2 & 1.93 & (27) \\
\hline & $16-28$ & 2Bk1 & $4-16$ & $1.8 \mathrm{e}$ & $45-53$ & S14c: & T01-0991 & $2 \times 2.6+4 \times 1.7+12 \times 1.8+33 \times 2.2$ & 105.0 & 2.06 & (51) \\
\hline & $28-50$ & $2 \mathrm{Bk} 2$ & $16-28$ & $2.2 \mathrm{e}$ & $70-83$ & S14d: & T01-0992 \& & $2 \times 2.6+4 \times 1.7+12 \times 1.8+60.5 \times 2.2$ & 165.5 & 2.16 & $(78.5)$ \\
\hline & $50-85$ & 2Bky & $28-85$ & $2.2 \mathrm{e}$ & (dup) & & & $2 \times 2.6+4 \times 1.7+12 \times 1.8+69 \times 2.2+30 \times 2.4$ & 256.2 & 2.23 & $(117)$ \\
\hline & $85-160+$ & $2 \mathrm{C}$ & $85-220$ & $2.4 \mathrm{e}$ & $110-120$ & S14e: & T01-1022 & $2 \times 2.6+4 \times 1.7+12 \times 1.8+69 \times 2.2+72.5 \times 2.4$ & 358.2 & 2.27 & $(159.5)$ \\
\hline & & & (Pro- & & $150-165$ & S14f: & NA & $2 \times 2.6+4 \times 1.7+12 \times 1.8+69 \times 2.2+135 \times 2.4$ & 508.2 & 2.31 & $(222)$ \\
\hline & & & file not & & $215-225$ & S14g: & T01-1023 & & & & \\
\hline
\end{tabular}


Table A6. Bulk-density calculations for depth-profile samples.-Continued

[Soil-horizon nomenclature from Soil Survey Staff, 1993 and 1999, and Birkeland, 1999, with these exceptions: dp, desert pavement; Av, vesicular A. Abbreviations: BD, bulk density; NA, not applicable or available; e, estimated value; $\mathrm{g} / \mathrm{cm}^{2}$, grams per square centimeter; $\mathrm{g} / \mathrm{cm}^{3}$, grams per cubic centimeter]

\begin{tabular}{|c|c|c|c|c|c|c|c|c|c|c|c|}
\hline \multirow{2}{*}{$\begin{array}{c}\text { Site } \\
\text { no. }\end{array}$} & \multicolumn{2}{|c|}{$\begin{array}{l}\text { Depth for soil } \\
\text { horizon }\end{array}$} & \multicolumn{2}{|c|}{$\begin{array}{l}\text { Soil bulk density } \\
\text { (BD) }\left(\mathrm{g} / \mathrm{cm}^{3}\right)\end{array}$} & \multicolumn{3}{|c|}{$\begin{array}{l}\text { Sampling depth }(\mathrm{cm}), \text { soil } \\
\text { sample no., and Prime } \\
\text { Laboratory no. }\end{array}$} & \multirow[t]{2}{*}{$\begin{array}{l}\text { Thicknesses }(\mathrm{cm}) \text { and bulk densities } \\
\qquad\left(\mathrm{g} / \mathrm{cm}^{3}\right) \text { above sample }\end{array}$} & \multirow{2}{*}{$\begin{array}{c}\begin{array}{c}\text { Mass } \\
\text { above } \\
\text { sample } \\
\left(\mathbf{g} / \mathbf{c m}^{2}\right)\end{array} \\
40.9\end{array}$} & \multicolumn{2}{|c|}{$\begin{array}{c}\text { Average BD and } \\
\text { thickness above } \\
\text { sample }\end{array}$} \\
\hline & $2-0$ & $\mathrm{dp}$ & $2-0$ & $2.6 \mathrm{e}$ & $15-25$ & S15a: & NA & & & 1.86 & $(22)$ \\
\hline & $0-3$ & Av & $0-3$ & $1.7 \mathrm{e}$ & $50-60$ & S15b: & NA & $2 \times 2.6+3 \times 1.7+17 \times 1.8+25 \times 2.2+10 \times 2.4$ & 119.9 & 2.10 & $(57)$ \\
\hline & $3-20$ & $2 \mathrm{Btkz}$ & $3-20$ & $1.8 \mathrm{e}$ & $83-92$ & S15c: & NA & $2 \times 2.6+3 \times 1.7+17 \times 1.8+25 \times 2.2+42.5 \times 2.4$ & 197.9 & 2.21 & $(89.5)$ \\
\hline & $20-45$ & 2Bk1 & $20-45$ & $2.2 \mathrm{e}$ & $120-130$ & S15d: & NA & $2 \times 2.6+3 \times 1.7+17 \times 1.8+25 \times 2.2+80 \times 2.4$ & 287.9 & 2.27 & $(127)$ \\
\hline & $45-90+$ & $2 \mathrm{Bk} 2$ & $\begin{array}{l}45-205 \\
\text { (Profile not } \\
\text { sampled } \\
\end{array}$ & $2.4 \mathrm{e}$ & $190-205$ & S15e: & NA & $2 \times 2.6+3 \times 1.7+17 \times 1.8+25 \times 2.2+152.5 \times 2.4$ & 461.9 & 2.32 & $(199.5)$ \\
\hline \multirow[t]{7}{*}{ S16 } & $2-0$ & $\mathrm{dp}$ & $2-0$ & $2.6 \mathrm{e}$ & $16-24$ & S16a: & T02-0823 & $2 \times 2.6+3 \times 1.7+17 \times 1.8$ & 40.9 & 1.86 & (22) \\
\hline & $0-3$ & Av & $0-3$ & $1.7 \mathrm{e}$ & $38-46$ & S16b: & T02-0824 & $2 \times 2.6+3 \times 1.7+17 \times 1.8+21 \times 2.0$ & 82.9 & 1.93 & (44) \\
\hline & $3-15$ & Btkz & $3-20$ & $1.8 \mathrm{e}$ & $70-80$ & S16c: & T02-0825 & $2 \times 2.6+3 \times 1.7+17 \times 1.8+35 \times 2.0+20 \times 2.3$ & 156.9 & 2.04 & (77) \\
\hline & $15-20$ & Btk & $20-55$ & $2.0 \mathrm{e}$ & $110-120$ & S16d: & T02-0826 & $2 \times 2.6+3 \times 1.7+17 \times 1.8+35 \times 2.0+60 \times 2.3$ & 248.9 & 2.13 & (117) \\
\hline & $20-55$ & Bky & $55-175$ & $2.3 \mathrm{e}$ & $170-175$ & S16e: & R02-1474 & $2 \times 2.6+3 \times 1.7+17 \times 1.8+35 \times 2.0+117.5 \times 2.3$ & 381.2 & 2.18 & $(174.5)$ \\
\hline & $55-105$ & By & (Profile not & & & & & & & & \\
\hline & $105+$ & $\mathrm{C}$ & sampled) & & & & & & & & \\
\hline \multirow[t]{6}{*}{ S17 } & $2-0$ & $\mathrm{dp}$ & $2-0$ & $2.6 \mathrm{e}$ & $20-28$ & S17a: & T01-0999 & $2 \times 2.6+6 \times 1.7+14 \times 1.8+4 \times 2.2$ & 49.4 & 1.90 & (26) \\
\hline & $0-6$ & Av & $0-6$ & $1.7 \mathrm{e}$ & $55-65$ & S17b: & T01-1000 & $2 \times 2.6+6 \times 1.7+14 \times 1.8+35 \times 2.2+5 \times 2.3$ & 129.1 & 2.08 & $(62)$ \\
\hline & $6-20$ & Btz & $6-20$ & $1.8 \mathrm{e}$ & $95-108$ & S17c: & T01-1001 & $2 \times 2.6+6 \times 1.7+14 \times 1.8+35 \times 2.2+46.5 \times 2.3$ & 224.6 & 2.17 & $(103.5)$ \\
\hline & $20-55$ & Btk & $20-55$ & $2.2 \mathrm{e}$ & $140-155$ & S17d: & T01-1002 & $2 \times 2.6+6 \times 1.7+14 \times 1.8+35 \times 2.2+55 \times 2.3+$ & 334.1 & 2.23 & $(149.5)$ \\
\hline & $55-110$ & Btj & $55-110$ & $2.3 \mathrm{e}$ & $200-215$ & S17e: & T01-1003 & $37.5 \times 2.4$ & 478.1 & 2.28 & $(209.5)$ \\
\hline & $110+$ & $\mathrm{Bk}$ & $\begin{array}{r}110-205 \\
\text { (Profile not } \\
\text { sampled) } \\
\end{array}$ & $2.4 \mathrm{e}$ & & & & $\begin{array}{l}2 \times 2.6+6 \times 1.7+14 \times 1.8+35 \times 2.2+55 \times 2.3+ \\
\quad 97.5 \times 2.4\end{array}$ & & & \\
\hline
\end{tabular}


Table A7. Slope aspect and orientation, elevation and orientation of the horizon for depth-profile sampling

[Abbreviations: asl, above sea level; m, meters; nd, no data]

\begin{tabular}{|c|c|c|c|c|c|c|c|c|c|c|c|c|c|}
\hline \multirow{2}{*}{$\begin{array}{l}\text { Sampling } \\
\text { site }\end{array}$} & \multirow{2}{*}{$\begin{array}{l}\text { Location, slope aspect @ } \\
\text { azimuth, and elevation } \\
\text { (asl) }\end{array}$} & \multicolumn{12}{|c|}{ Zenith angle for horizon at measured azimuths } \\
\hline & & $0^{\circ}$ & $30^{\circ}$ & $60^{\circ}$ & $90^{\circ}$ & $120^{\circ}$ & $150^{\circ}$ & $180^{\circ}$ & $210^{\circ}$ & $240^{\circ}$ & $270^{\circ}$ & $300^{\circ}$ & $330^{\circ}$ \\
\hline S2 & $\begin{array}{l}\text { Trail Canyon fan, } 8^{\circ} @ \\
050^{\circ}, 224 \mathrm{~m}\end{array}$ & 2.5 & 3.5 & 2.0 & 5.0 & 3.5 & 1.5 & 4.0 & 7.0 & 12.5 & 10.0 & 11.0 & 5.0 \\
\hline S3 (SPV-3) & $\begin{array}{c}\text { Cow Creek fan, } 3^{\circ} @ \\
315^{\circ},-47 \mathrm{~m}\end{array}$ & nd & nd & nd & nd & nd & nd & nd & nd & nd & nd & nd & nd \\
\hline S5 & $\begin{array}{l}\text { Hanaupah Canyon spit, } \\
3^{\circ} @ 080^{\circ}, 27 \mathrm{~m}\end{array}$ & 0.5 & 1.0 & 4.0 & 5.0 & 2.5 & 1.0 & 2.3 & 7.0 & 9.5 & 9.5 & 8.0 & 2.5 \\
\hline S6 & $\begin{array}{l}\text { Galena Canyon fan, } 6^{\circ} \\
\text { @ } 070^{\circ}, 61 \mathrm{~m}\end{array}$ & 1.1 & 3.8 & 5.4 & 6.9 & 1.5 & 1.9 & 2.9 & 5.4 & 6.2 & 8.6 & 7.5 & 4.0 \\
\hline S7 & $\begin{array}{l}\text { Galena Canyon fan, } 9^{\circ} \\
\text { @ } 094^{\circ}, 8 \mathrm{~m}\end{array}$ & 1.1 & 3.8 & 5.4 & 6.9 & 1.5 & 1.9 & 2.9 & 5.4 & 6.2 & 8.6 & 7.5 & 4.0 \\
\hline S8 & $\begin{array}{c}\text { Hanaupah Canyon fan, } \\
7^{\circ} @ 070^{\circ}, 55 \mathrm{~m}\end{array}$ & 1.5 & 2.5 & 5.0 & 4.5 & 3.0 & 1.0 & 2.0 & 7.0 & 11.5 & 11.0 & 9.0 & 4.0 \\
\hline S9 & $\begin{array}{c}\text { Hanaupah Canyon fan, } \\
3.5^{\circ} @ 070^{\circ}, 73 \mathrm{~m}\end{array}$ & 1.0 & 3.5 & 4.0 & 7.0 & 4.5 & 2.5 & 3.5 & 7.0 & 12.0 & 11.5 & 6.5 & 3.5 \\
\hline S10 & $\begin{array}{l}\text { Hanaupah Canyon fan, } \\
7^{\circ} @ 074^{\circ}, 84 \mathrm{~m}\end{array}$ & 0.5 & 3.5 & 4.0 & 7.0 & 4.5 & 2.5 & 3.0 & 7.0 & 10.0 & 11.5 & 6.5 & 3.5 \\
\hline S11 & $\begin{array}{l}\text { Hanaupah Canyon fan, } \\
8^{\circ} @ 088^{\circ}, 306 \mathrm{~m}\end{array}$ & 2.0 & 2.0 & 4.5 & 4.0 & 4.0 & 1.0 & 3.5 & 6.0 & 12.0 & 11.0 & 10.0 & 3.0 \\
\hline $\mathrm{S} 12$ & $\begin{array}{c}\text { Hanaupah Canyon fan, } \\
7^{\circ} @ 096^{\circ}, 98 \mathrm{~m}\end{array}$ & 0.5 & 3.5 & 4.0 & 7.0 & 4.5 & 2.5 & 3.0 & 7.0 & 10.0 & 11.5 & 6.5 & 3.5 \\
\hline S14 & $\begin{array}{c}\text { Mile } 22 \text { fan SW of fault, } \\
5.5^{\circ} @ 230^{\circ}, 366 \mathrm{~m}\end{array}$ & 5.0 & 9.5 & 11.5 & 8.5 & 5.0 & 0.5 & 1.5 & 3.0 & 6.5 & 7.0 & 3.0 & 2.5 \\
\hline S15 & $\begin{array}{l}\text { Mile } 22 \text { fan NE of fault, } \\
5^{\circ} @ 225^{\circ}, 376 \mathrm{~m}\end{array}$ & 5.5 & 11.0 & 11.5 & 8.0 & 4.5 & 0.5 & 2.0 & 2.5 & 6.0 & 7.0 & 3.0 & 3.5 \\
\hline S16 & $\begin{array}{l}\text { Echo Canyon fan, } 8^{\circ} @ \\
250^{\circ}, 195 \mathrm{~m}\end{array}$ & 2.5 & 7.0 & 6.0 & 8.5 & 6.0 & 4.0 & 5.0 & 3.5 & 5.0 & 3.0 & 2.0 & 1.0 \\
\hline S17 & $\begin{array}{l}\text { Mustard Canyon Hills } \\
4^{\circ} @ 270^{\circ},-12 \mathrm{~m}\end{array}$ & 3.5 & 4.0 & 6.5 & 8.0 & 5.0 & 4.0 & 0.5 & 5.5 & 4.0 & 5.0 & 2.0 & 1.0 \\
\hline
\end{tabular}




\section{Terrestrial Cosmogenic-Nuclide Dating of Alluvial Fans in Death Valley, California}

Table A8. Estimated surface erosion or aggradation rates for depth-profile sampling sites.

[Abbreviations: Max, maximum; Min, minimum, Pref, preferred; cm, centimeters; mm/kyr, millimeters per thousand years]

\begin{tabular}{|c|c|c|c|c|}
\hline \multirow{2}{*}{$\begin{array}{l}\text { Sam- } \\
\text { pling } \\
\text { site }\end{array}$} & \multirow[t]{2}{*}{ Geomorphic setting and sampling location } & \multicolumn{3}{|c|}{$\begin{array}{c}\text { Erosion (-) or aggrada- } \\
\text { tion }(+) \text { rate }(\mathrm{mm} / \mathrm{kyr})\end{array}$} \\
\hline & & Max & Min & Pref \\
\hline S3 & $\begin{array}{l}\text { Mutted bar and swale topography. Sampled in long fault trench, Weak soil; erosion may equal } \\
\text { aggradation. }\end{array}$ & -0.5 & +0.5 & 0.0 \\
\hline $\mathrm{S} 2$ & Slightly undulatory alluvial surface. Sampled in soil pit. Erosion may offset aggradation. & -2.0 & +2.0 & 0.0 \\
\hline S5 & $\begin{array}{l}\text { Planar relict surface of deltaic feature. Sampled from dissected edge of deeply incised; } 10-20 \mathrm{~cm} \text { of } \\
\text { erosion possible. Erosion may offset aggradation. }\end{array}$ & -2.0 & +2.0 & 0.0 \\
\hline S6 & Slight relict bar and swale topography, sampled from flat interfluve in soil pit. Net aggradation. & 0.0 & +3.0 & +2.0 \\
\hline S7 & Slight relict bar and swale topography, sampled from flat interfluve in soil pit. Net aggradation. & 0.0 & +3.0 & +2.0 \\
\hline S8 & $\begin{array}{l}\text { Relatively flat area on rounded knoll, dissected on three sides. Sampled in soil pit. Soil suggests as } \\
\text { much as } 30 \mathrm{~cm} \text { of erosion. }\end{array}$ & -3.0 & +2.0 & -1.0 \\
\hline S9 & $\begin{array}{l}\text { Slight relict bar and swale topography, sampled from edge of surface incised by modern channel. Net } \\
\text { aggradation. }\end{array}$ & 0.0 & +3.0 & +2.0 \\
\hline S11 & $\begin{array}{l}\text { Planar relict surface with occasional large boulders } 0.5-1 \mathrm{~m} \text { above surface. Dissected channels typical, } \\
\text { but not at sampling site (soil pit). Net aggradation. }\end{array}$ & 0.0 & +3.0 & +2.0 \\
\hline $\mathrm{S} 12$ & $\begin{array}{l}\text { Slightly lowered surface relative to adjacent relict surfaces. Sampled in soil pit; } 10-20 \mathrm{~cm} \text { of erosion } \\
\text { possible. Erosion may offset aggradation. }\end{array}$ & -2.0 & +2.0 & 0.0 \\
\hline S14 & $\begin{array}{l}\text { Planar relict surface. Sampled from edge of surface incised by modern channel. No significant } \\
\text { erosion. }\end{array}$ & 0.0 & +3.0 & +2.0 \\
\hline S15 & Planar relict surface. Sampled from edge of surface incised by modern channel. Net aggradation. & 0.0 & +3.0 & +2.0 \\
\hline $\mathrm{S} 16$ & $\begin{array}{l}\text { Uplifted, tilted relict surface. Sampled from edge of deeply eroded surface. Slight erosion }(10-20 \mathrm{~cm}) \\
\text { may offset aggradation. }\end{array}$ & -2.0 & +3.0 & +0.0 \\
\hline S17 & $\begin{array}{l}\text { Uplifted, tilted relict surface. Sampled from edge of surface incised by modern channel. Slight erosion } \\
(10-20 \mathrm{~cm}) \text { may offset aggradation. }\end{array}$ & -2.0 & +3.0 & +0.0 \\
\hline
\end{tabular}


Publishing support provided by:

Denver Publishing Service Center, Denver, Colorado

Manuscript approved for publication, May 2008

Edited by Mary A. Kidd

Graphics and layout by Sharon Powers 
ISBN $\quad 978-141132187-8$ 